\title{
MMSTER
}

\section{O Geothermal Energy in Washington: Site Data Base and Development Status}

by

R. Gordon Bloomquist, Ph.D.

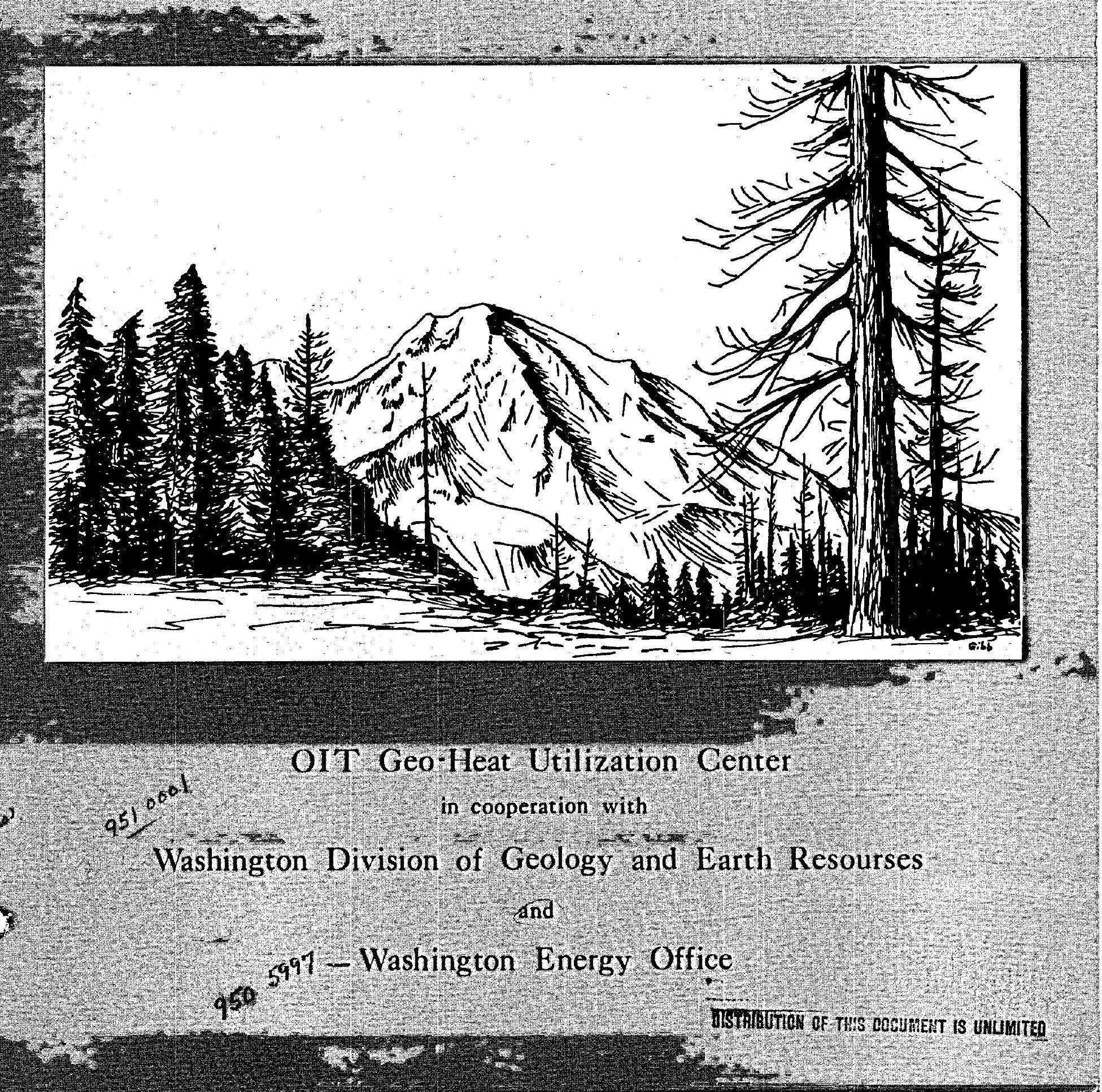




\section{DISCLAIMER}

This report was prepared as an account of work sponsored by an agency of the United States Government. Neither the United States Government nor any agency Thereof, nor any of their employees, makes any warranty, express or implied, or assumes any legal liability or responsibility for the accuracy, completeness, or usefulness of any information, apparatus, product, or process disclosed, or represents that its use would not infringe privately owned rights. Reference herein to any specific commercial product, process, or service by trade name, trademark, manufacturer, or otherwise does not necessarily constitute or imply its endorsement, recommendation, or favoring by the United States Government or any agency thereof. The views and opinions of authors expressed herein do not necessarily state or reflect those of the United States Government or any agency thereof. 


\section{DISCLAIMER}

Portions of this document may be illegible in electronic image products. Images are produced from the best available original document. 


\section{0}

DISCLAIMER

This report was prepared as an account of work sponsored by the United States Government. Neither the United States nor the United States Department of Energy, nor any of their employees, nor any of their contractors, subcontractors, or their employees, makes any warranty, expressed or implied, or assumes any legal liability or responsibility for the accuracy, completeness or usefulness of any information, apparatus, product or process disclosed, or represents that its use would not infringe privately-owned rights. 


\title{
MASTER
}

\section{Geothermal Energy in Washington:}

\section{Site Data Base and Development Status}

\author{
Prepared for
}

\section{U.S. Department of Energy (USDOE)}

San Francisco Operations Office

Oakland, California

Contract No. DE-AC03-79SF1049

by

R. Gordon Bloomquist, Ph.D.

Geo-Heat Utilization Center

April, 1979 


\section{Foreword}

Among the most critical of problems facing our nation is energy resources. Though there may be minor disagreement about the specifics, malgnitude and solutions to these problems there can be no question about their urgency and of the necessity for immediate action. In an effort to in part resolve these questions by accelerating utilization of one of our renewable resources, the $U$. S. Department of Energy has developed a program of National and Regional Planning and Operations Research of geothermal energy resources.

The OIT Geo-Heat Utilization Center, under contract to USDOE, has evaluated the geothermal energy resource development potential of the six northwest states of Alaska, Idaho, Montana, Oregon, Washington, and Wyoming. Our goal has been to summarize for this region on a site-specific basis the various factors affecting development including resource data base, geological description, reservoir characteristics, environmental character, lease and development status, institutional factors, economics, population and market, and finally potential for development. This report summarizes the known data base for the state of Washington, and is in this sense an . appendix to the regional report being prepared at the Geo-Heat.Utilization Center.

As so little geothermal resource data is available this then represents a progress report in a young but rapidly developing field of knowledge. The continuation of this project now underway is attempting to complete this core of site information and identify data on new significant sites, provide accurate information and recommendations to policy and decision-makers, and ultimately to assist in evolving more effective regional and national geothermal energy programs.

June, 1979 
$\mathcal{U}$ 


\section{PREFACE}

This study is a first attempt at assembling all of the available information on the factors which are or are expected to affect geothermal development at a selected number of potential geothermal sites in Washington. These sites, which include Mount Adams PGRA (Potential Geothermal Resource Area), Indian Heaven KGRA (Known Geothermal Resource Area), Mount St. Helens KGRA, Mount Rainier PGRA, Kennedy Hot Springs KGRA, Mount Baker PGRA, Yakima, and 01ympic-Sol Duc Hot Springs, were selected on the basis of their geothermal potential as determined by the U.S. Geological Survey or on the recommendation of the Washington Division of Geology and Earth Resources and the Washington Energy Office.

These eight sites can in no way be considered to comprise a majority of the potential sites in the state nor do they represent those sites whose development is assured. In fact, some of the sites were determined to have little near term geothermal development potential due to geological factors, distance from potential users, environmental concerns, or resource assessability.

The study identified a number of serious impediments to geothermal development which can be solved only by legislative action at the state or federal level and/or changes in attitudes by regulatory agencies. The identification of these impediments has resulted in a number of suggested changes or additions to existing legislation, and it is hoped that suceeding volumes of this study will be able to identify a series of incentives to development in place of the impediments found herein.

Future volumes will include additional potential deveiopment sites, as well as updates of the eight sites with which this study is concerned.

This work would not be nearly as complete without the assistance and cooperation of a great number of individuals, groups, and governmental agencies. Although it is not possible to mention all of the various individuals who provided information and/or advice, I would like to express my gratitude to everyone who has made this work possible.

A few individuals and groups, however, stand out in my mind as the source for the basis of this work and I would like to express my special appreciation to them: Eric Schuster for guiding my first months in Washington and for sharing with me throughout the year all of the experience he had gained in working with geothermal in Washington for several years; Fred Adair, Steve Craig, and Suzi Hosch for lending the full support of the Washington Energy Office; Jerald Hutchins for providing information on the Gifford Pinchot National Forest; Bob Taylor for sharing with me a great deal of his work concerning the Mount Baker - Snoqualmie National Forest; James Coleman, Jr., for the full cooperation of the staff of 0lympic National Park; Don Karr and Robert Koeppen for directing and coordinating 
the entire project from 0IT, and to the entire 0IT Geo-Heat Utilization Center staff for all of the lengthy discussions and shared ideas.

I would like to give special thanks to Jerry Mayo for days, nights, and weekends spent typing the numerous drafts, to Laura Bray for an excellent job of editing, and to Gibb Johnson and Keith Ikerd for the cartography. 
Washington State energy situation (by Steven J. Craig) . . . XIII

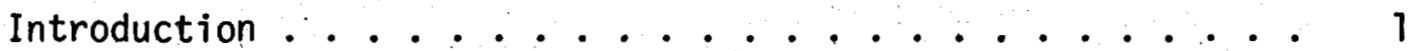

The Cascade Range Geothermal Province ......... 7

Mount Adams PGRA .................... 11

Introduction ............. 13

Site data summary ............. 15

Site location and physical description ....... 17

Geological/geophysical description ........ 18

Reservoir characteristics .......... 20

Land ownership and leasing ............. 21

Geothermal development status .......... 22

Institutional characteristics .......... 23

Environmental factors............ 24

Transportation and utilities ......... 26

Population ................. . . 27

Indian Heaven KGRA .............. 29

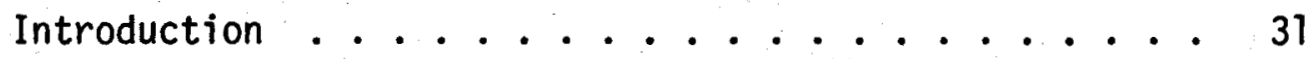

Site data summary .............. . . 33

Site location and physical description ...... 35

Geological/geophysical description ....... 36

Reservoir characteristics ......... 37

Land ownership and leasing .......... 38

Geotherma1 development status ......... 39

Institutional characteristics .......... 40

Environmental factors .................... 41

Transportation and utilities ......... 43

Population ................... . . 44

Mount St. Helens KGRA .............. 45

Introduction ................... 47

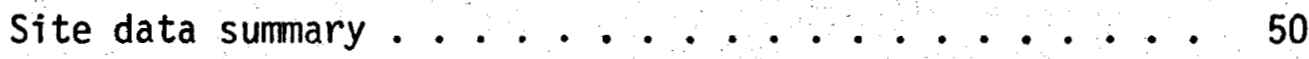

Site location and physical description . . . . . . 52

Geological/geophysical description ....... 53 
Mount St. Helens KGRA - Continued

Reservoir characteristics .......... 57

Land ownership and leasing ......... 58

Geothermal development status ......... 59

Institutional considerations ........ 60

Environmental factors ........... 61

Transportation and utilities ......... 63

Poputation .................... 64

Mount Rainier PGRA ............. . . 65

Introduction ...................... 67

Site data summary ............ 70

Site location and physical description . . . . 72

Geological/geophysical description . . . . 73

Reservoir characteristics ......... 76

Land ownership and leasing ........ . . 77

Geothermal development status . . . . . . 78

Institutional characteristics . . . . . . . 79

Environmental factors ........... 80

Transportation and utilities ......... 82

Population ................. 83

Kennedy Hot Springs KGRA . . . . . . . . . 85

Introduction ................ 87

Site data summary ............ 88

Site location and physical description .... . . 89

Geological/geophysical description ....... 9 90

Reservoir characteristics . . . . . . . . 92

Land ownership and leasing . . . . . . . . . . 93

Geothermal development status ......... 94

Institutional characteristics ......... 95

Environmental factors ............. 96

Transportation and utilities ........... 98

Population ................... 99

Mount Baker PGRA . . . . . . . . . . 101

Introduction ................... 103

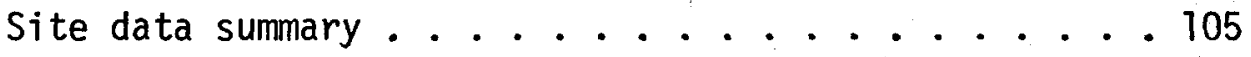

Site location and physical description ...... 107

Geological/geophysical description ....... 108 
Reservoir characteristics . . . . . . . 112

Land ownership and leasing . . . . . . . . 113

Geothermal development status . . . . . . 114

Institutional characteristics . . . . . . . . 115

Environmental factors . . . . . . . . 116

Transportation and utilities ......... . . 118

Population ...................... 119

Yakima...................... 121

Introduction .............. . 123

Site data summary . . . . . . . . . . . 125

Location and physical description . . . . . . . 126

Geological/geophysical description . . . . . 127

Reservoir characteristics .......... 128

Land ownership and leasing .......... 129

Geothermal development status ......... 130

Institutional characteristics . . . . . . . 131

Environmental factors ............ 132

Transportation and utilities ......... 134

Population .................. 135

Olympic and Sol Duc Hot Springs . . . . . . . . 137

Introduction ............... . . 139

Site data summary ................ 141

Site location and physical description ..... 143

Geological/geophysical description . . . . . 144

Reservoir characteristics . . . . . . . . 145

Land ownership and leasing . . . . . . . 146

Geothermal development status ........... 147

Institutional characteristics . . . . . . . 148

Environmental factors ........... 149

Transportation and utilities ................ 151

Population . . . . . . . . . . . 152 
Page

Legal and institutional factors affecting geothermal assessment and development in Washington ...... 153

Selected references . . . . . . . . . 157

Appendix .................. 167

I. Geothermal Steam Act of $1970 \ldots 168$

II. RCW 79.76 (Geothermal Resources Act) . . . . 180 


\section{ILLUSTRATIONS}

Page

Figure 1. Geothermal land classification map of Washington State ......... 2

2. Location of chemically analyzed springs and rivers in relation to (1968) population distribution in Washington ... 4

3. Locations of chemically analyzed springs and rivers in the Cascade Range, Washington .......... 6

4. Geothermal land classification map -

Mount Adams PGRA .......... 12

5. Geothermal land classification map -

Indian Heaven KGRA ........ 30

6. Geothermal land classification map -

Mount St. Helens KGRA ........446

7. Geothermal land classification map -

Mount Rainier PGRA . ........ 66

8. Geothermal land classification map -

Kennedy Hot Springs KGRA ....... 86

9. Geothermal land classification map -

Mount Baker PGRA . . . . . . . . 102

10. Geothermal land classification map -

Yakima ......... . . . . 122

11. Geothermal land classification map -

Olympic and Sol Duc Hot Springs .....138

Table 1. Chemical data for springs and rivers in the

Cascade Range, Washington ...... 8-9 
U 


\section{WASHINGTON STATE ENERGY SITUATION}

(Projected)

by

Steven J. Craig

(Washington State Energy Office Information Management Supervisor)

The State of Washington like the rest of the nation is at an energy crossroads. With the hydroelectric potential of the state and region nearly exhausted (within a time span of 50 years), Washington and its neighboring states are now forced to make the transition to thermalelectric resources, namely nuclear and coal. With no significant reserves of oil or gas and with coal deposits largely uneconomically extractable, Washington continues its dependence on these resources imported from outside the state. Self reliance, which substantially. characterized Washington's energy situation in the past, is increasingly giving way to greater dependence on outside energy sources and with that an increasing vulnerability to embargoes, cartels and higher prices.

As the state has grown in population and economic diversity, so too has the demand for more energy (table 1, Fig.1). In a recent 10-year period (1964-1974), the overall annual energy growth rate for the state averaged 3.52 percent (table 2). And while the consumption of some fuel types decreased during this period, others including natural gas and electricity increased at an annual rate of 5.29 percent and 5.79 percent, respectively. The significance of these and other fuel-source growth rates taken collectively is that, should they continue, energy needs for Washington State would likely double in approximately 20 to 25 years.

As a means of dealing with the formidable task of meeting Washington's projected energy needs, the state is simultaneously pursuing three courses of action including:

1. Facilitation of the timely development of thermal-electric power plants.

2. Promotion of energy conservation and utilization efficiency by all consuming sectors.

3. Facilitation of the timely development of the state's potential renewable energy resources.

All of these actions are going to be required if the state is to avoid energy shortages in the next two decades and beyond. Thus, the potential for utilizing geothermal energy as well as other renewable energy resources will continue to be assessed and where determined feasible efforts will be directed toward bringing these resources on-line. 

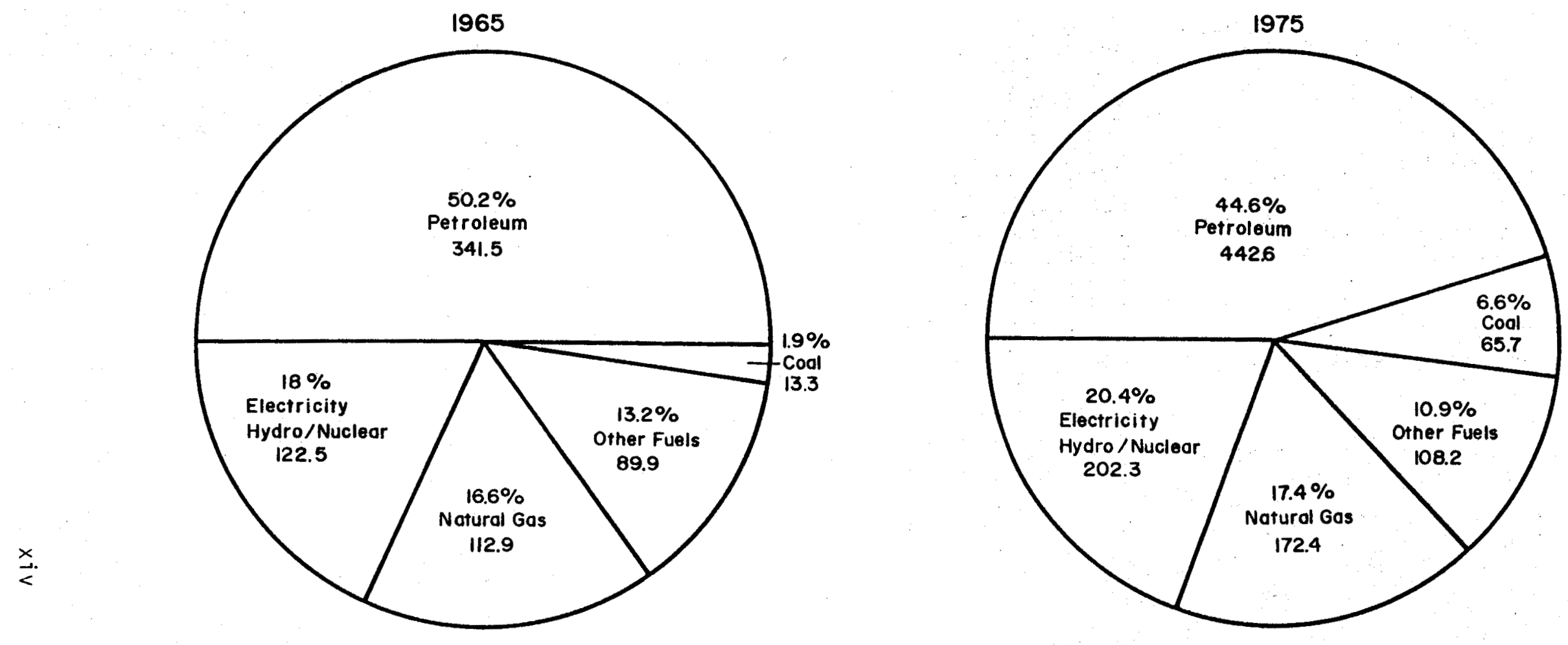

FIG. 1

WASHINGTON STATE

GROSS ENERGY CONSUMPTION 1965/1975

(Trillions of BTU's)

Source: Federal Energy Data System (FEDS) Statistical Sumiary, February, 1978, By Raymond F. Fuller, U.S. DOE Energy Information Administration, Division of Consumption Data Studies, WA D.C. 
TABLE 1

WASHINGTON STATE GROSS ENERGY CONSUMPTION 1965/1975

(Trillions of BTU's)

$\begin{array}{lccc} & 1965 & 1975 & \% \text { Change } \\ \text { Gasoline } & 142.17 & 216.79 & 52.5 \\ \text { Distillate 0i1 \& Kerosene } & 85.23 & 77.87 & -8.6 \\ \text { Diesel Fuel } & 16.26 & 20.89 & 28.4 \\ \text { Residual 0il } & 55.48 & 53.89 & -2.9 \\ \text { Liquid Petroleum Gas } & 4.93 & 3.06 & -37.9 \\ \text { Jet Fuel } & 37.41 & 70.13 & 87.5 \\ \text { Natural Gas } & 112.95 & 172.43 & 52.7 \\ \text { Anthracite/ } & & & \\ \text { Bituminous Coal } & 13.3 & 65.68 & 393.8 \\ \text { Electricity Nuclear/ } & & & 65.2 \\ \text { Hydro } & 122.49 & 202.35 & 20.3 \\ \text { Other Fuels } & 89.94 & 108.24 & 45.7 \\ \text { Totals } & 680.16 & 991.28 & \end{array}$

Source: Federal Energy Data System (FEDS) Statistical Summary, February 1978. By Raymond F. Fuller, U.S. DOE Energy Information Administration, Division of Consumption Data Studies, Washington, D.C. 
TABLE 2

RATES OF GROWTH IN ENERGY CONSUMPTION AND ASSOCIATED DOUBLING TIMES

Percentage Increases Per Year Forecasted (1974-2000)

\begin{tabular}{|c|c|c|c|c|c|c|c|c|}
\hline WASHINGTON & $\begin{array}{l}\text { Historical } \\
(1964-1974)\end{array}$ & $\begin{array}{l}\text { Doubling } \\
\text { time yrs. }\end{array}$ & $\begin{array}{l}\text { Low } \\
\text { Growth }\end{array}$ & $\begin{array}{l}\text { Doubling } \\
\text { time yrs. }\end{array}$ & $\begin{array}{l}\text { Moderate } \\
\text { Growth }\end{array}$ & $\begin{array}{l}\text { Doubling } \\
\text { time yrs. }\end{array}$ & $\begin{array}{l}\text { High } \\
\text { Growth }\end{array}$ & $\begin{array}{l}\text { Doubling } \\
\text { time yrs. }\end{array}$ \\
\hline $\begin{array}{l}\text { Electricity } \\
\text { Natural Gas } \\
\text { Oil } \\
\text { Coal } \\
\text { Wood } \\
\text { Total }\end{array}$ & $\begin{array}{l}5.79 \\
5.29 \\
2.04 \\
-- \\
-- \\
3.52\end{array}$ & $\begin{array}{l}12 \\
13 \\
34\end{array}$ & $\begin{array}{l}1.44 \\
0.63 \\
0.84 \\
5.35 \\
1.47 \\
1.04\end{array}$ & $\begin{array}{r}49 \\
111 \\
83 \\
13 \\
48 \\
67\end{array}$ & $\begin{array}{r}2.94 \\
2.06 \\
2.77 \\
10.12 \\
2.92 \\
2.83\end{array}$ & $\begin{array}{r}24 \\
34 \\
25 \\
7 \\
24 \\
25\end{array}$ & $\begin{array}{r}4.32 \\
2.84 \\
5.54 \\
12.65 \\
2.47 \\
4.90\end{array}$ & $\begin{array}{l}16 \\
25 \\
13 \\
5.5 \\
28 \\
14\end{array}$ \\
\hline
\end{tabular}

PACIFIC NORTHWEST

$\times \quad$ Electricity
Natural Gas
0il
Coàl
Wood
Total PNW

$\begin{array}{lrrrr}5.94 & 12 & 1.43 & 49 & 2.93 \\ 5.23 & 13 & 0.61 & 115 & 1.66 \\ 2.72 & 26 & 0.50 & 140 & 2.44 \\ -- & & 4.01 & 17 & 9.18 \\ -- & & 1.48 & 47 & 2.63 \\ 3.88 & 18 & .90 & 78 & 2.62\end{array}$

$\begin{array}{rr}24 & 4.38 \\ 42 & 4.38 \\ 29 & 5.00 \\ 8 & 10.84 \\ 27 & 2.20 \\ 27 & 4.56\end{array}$

16
16
14
6
32
15

NOTE: Doubling time - Refers to the amount of time required for "energy demand" to double assuming a given percentage growth rate over a given time period, i.e., as Table 1 indicates for electricity, and annual growth rate of 5.79 percent would result in demand doubling every 12 years.

SOURCE: Energy Futures Northwest, Northwest Energy Policy Project

Final Report Sponsored by Pacific Northwest Regional Commission, May 1978 
This report is an attempt by the author to identify the factors which have affected and will continue to affect geothermal assessment and development in the state. For purposes of this report, eight potential sites were chosen for detailed analysis by the author in consultation with the Washington Energy : Office and the Washington Division of Geology and Earth Resources. The eight sites include: Indian Heaven KGRA (Known Geothermal Resource Area), Mount St. Helens KGRA, Kennedy Hot Springs KGRA, Mount Adams PGRA (Potential Geothermal Resource Area), Mount Rainier PGRA, Mount Baker PGRA, 0lympic-Sol Duc Hot Springs, and Yakima.

Interest in geothermal energy in Washington began in the early 1970's and reached a high point in 1971 with the First Northwest Conference on Geothermal Power which was held in 0lympia and chaired by Bert Cole, Commissioner of Public Lands for the State of Washington. The conference was attended by delegates from throughout the Pacific Northwest and by several delegates from other areas of the United States.

This initial surge of interest was followed by considerable interest by industry, and a total of 238 lease applications were filed with BLM. Overlapping lease applications in the Indian Heaven and Mount St. Helens areas resulted in portions of these areas being classified as KGRA's by the U.S. Geological Survey. In addition to the Indian Heaven and Mount St. Helens areas so classified, Mount St. Helens and Kennedy Hot Springs were designated as KGRA's on the basis of geological evidence. Much of the Cascade Range "Geological" Province was designated as a PGRA by the survey (fig. 1). Two areas in Okanogan County also received PGRA status because of the presence of recent volcanics.

Since the initial filing of lease applications for some 491,728 acres, little interest has been shown in the state by private industry and many of the lease applications have been withdrawn. Amax Exploration, Inc., is the only company known to have done exploratory heat-flow drilling in the state. Burlington Northern has maintained a low profile program to assess the geothermal potential of company-owned properties in Washington.

The Washington Division of Geology and Earth Resources has continued to assess the geothermal potential of the state since 1972. As part of this assessment work the division has attempted to sample all of the known thermal and mineral springs in the state and to do detailed geochemical analyses of the sampled waters.

These geochemical data have been used to estimate reservoir temperatures for each spring system sampled. Many of the assumptions made as to the geothermal potential at any of the areas covered in detail by this report have been made on the basis of these geochemical data. (Please see Cascade Range, Geothermal Province, $p .10$, for a detailed account of the use of geothermometry and the assumptions upon which calculations are made.)

In 1975 the Division of Geology and Earth Resources was engaged in the drilling of seven heat-flow holes in the Indian Heaven area of the southern Cascades and results of this study comprise the most detailed 
FIG. I - GEOTHERMAL LAND CLASSIFICATION MAP OF WASHINGTON STATE

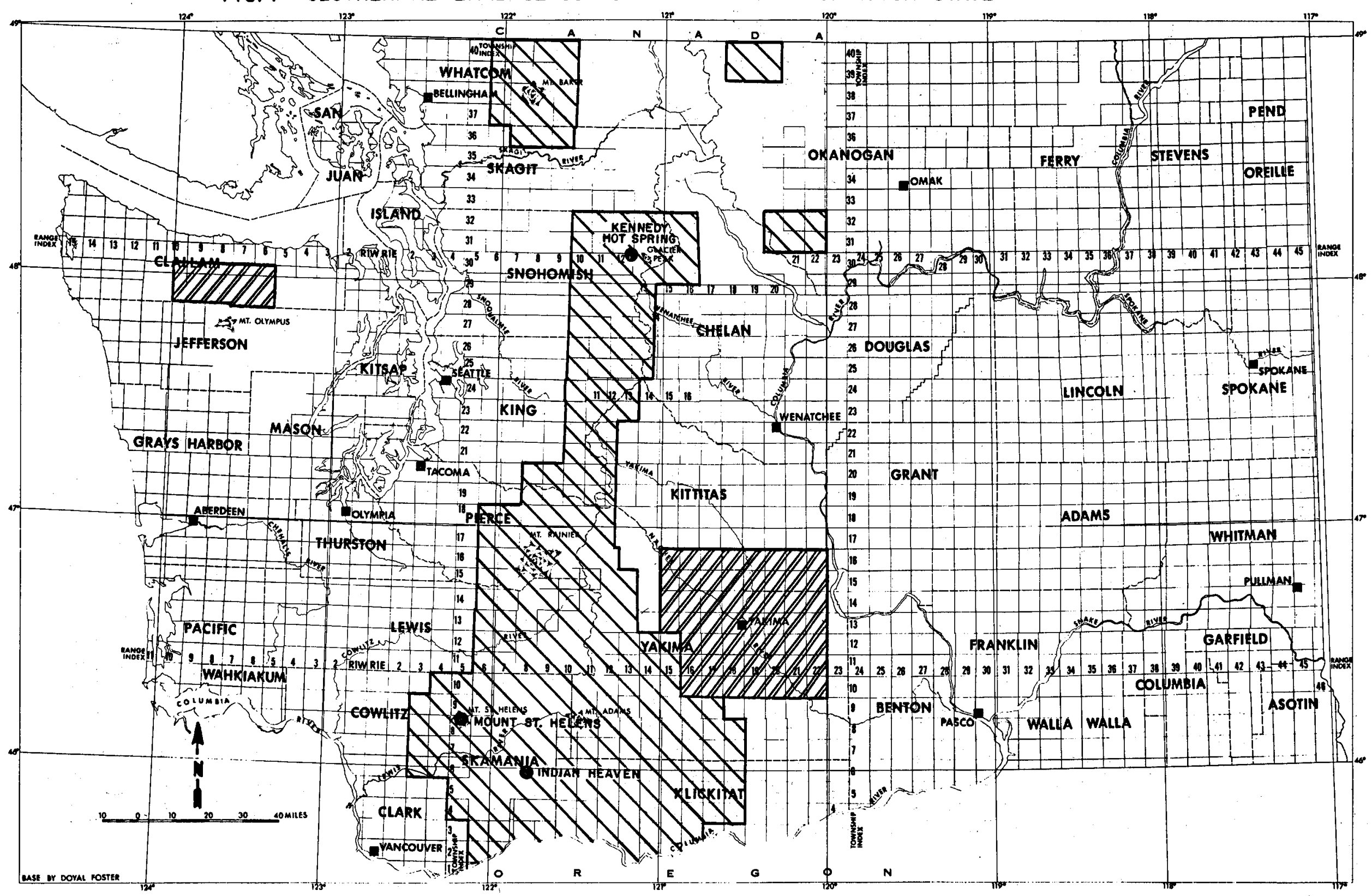

- KNOWN geothermal resources area DI LANDS VALUABLE PROSPECTIVELY fOR

AREA OF KNOWN WARM WATER USE 
information available concerning heat flow in the state and especially in the Cascade Range. In addition, the division has supported and/or cooperated in the following: (1) measuring thermal gradients and heat flows in mineral exploration drill holes and water wel1; (2) compiling existing geologic mapping and conducting detailed reconnaissance geologic mapping in the southern Cascades; (3) assessing the use of ground noise measurements as a geothermal exploration tool; (5) publishing reports on the locations of earthquake hypocenters; (6) producing an aeromagnetic map of a large part of the southern Cascades; (7) publishing a gravity map of the state; and (8) sponsoring a project designed to measure gravity in the Indian Heaven areas.

In f.y. 1978 the Division of Geology and Earth Resources in cooperation with Battelle has attempted to accelerate the assessment of the state's geothermal resources with a special emphasis on the Cascade Range. Unfortunately, due to lengthy contract negotiations and the late arrival of funds, the effort was confined to the resampling of known thermal and mineral springs, obtaining information on existing wells, and reviewing the literature.

Plans for f.y. 1979 include the development of the Cascade Range Geothermal Assessment Program involving the U.S. Geological Survey and the Washington Division of Geology and Earth Resources. A portion of the funding for this program will be provided by the U.S. Department of Energy, Division of Geothermal Energy.

The Division of Geology and Earth Resources intends to continue the geochemical assessment of the thermal and mineral springs in the state, while emphasizing those springs in the Cascades. A great aid in this work will be the acquisition of laboratory facilities and equipment for geochemical analysis. The division will also become increasingly involved in geological and geophysical assessment of Mount St. Helens as a portion of the first year of the program which is expected to continue for the next 3 to 5 years.

Lack of industry commitment to geothermal in the state and lack of industry sponsored assessment work can be attributed to the absence of highly promising surface manifestations close to potential service areas, the lack of access to potential geothermal resources underlying national forest lands through failure of the forest service to open the lands for leasing, and the location of several of the promising geothermal prospects in national parks or wilderness areas.

of the known thermal and mineral springs in the state only six spring systems exhibit $\mathrm{Na}-\mathrm{K}-\mathrm{Ca}$ temperatures of over $100^{\circ} \mathrm{C}\left(212^{\circ} \mathrm{F}\right)$. The seven spring systems include Mount Baker Hot Springs, Sulphur Hot Springs, Kennedy Hot Springs, Garland Mineral Springs, Ohanapecosh Hot Springs, Gamma Hot Springs, and Summit Creek Mineral Springs (Soda Springs). None of these spring systems exhibits a significant flow. These seven springs do however have a definite spatial relationship to the stratovolcanoes (Schuster et al, 1978). 

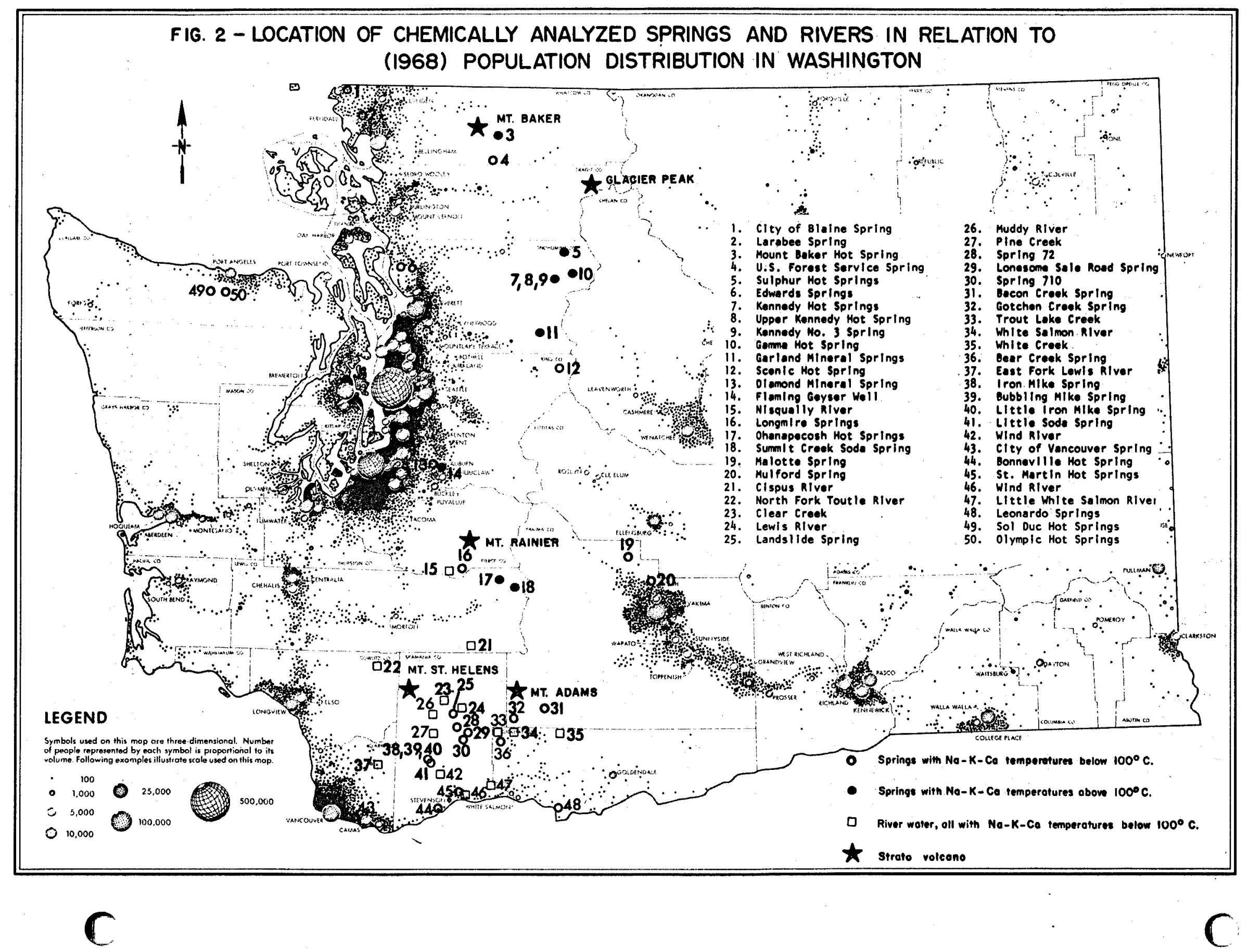
As can be clearly seen from figure 2 major population centers are all at considerable distances from the known surface manifestations in the state, and this is especially true of the seven spring systems listed above.

of all factors affecting the assessment and development of geothermal resources in Washington, the most serious has been lack of access to federal lands. Lands classified by the U.S. Geological Survey as valuable prospectively for geothermal resources are almost exclusively forest service administered lands. As of January 1, 1978, 238 lease app1ications had been filed on forest service lands in Washington. of this total, 92 were withdrawn primarily because of the failure to grant the leases within a reasonable period. One hundred and forty-five are still awaiting action. In addition, no lease sales have been held on lands in the three KGRA's in the state. The first lease sale is tentatively scheduled for March 13, 1979, and will be for lands in the Indian Heaven KGRA. A date for lease sales in the Mount St. Helens KGRA has not, as of this time, been set. The Kennedy Hot Spring KGRA is within the boundaries of the Glacier Peak Wilderness Area and therefore not open to leasing.

The issuing of leases awaits the completion and acceptance by the forest service of environmental statements concerning the potential impacts of geothermal exploration and development upon the lands for which lease applications exist. The first environmental statement in regard to geothermal was released in draft form by the forest service for public review and comment in January 1978 (Wheeler, 1978).

The EAR (Environmental Analysis Report) covered 334,448 acres in the Gifford Pinchot National Forest. The EAR was rewritten and released for review and comments in October, 1978. Final acceptance is expected in early 1979.

Thus the issuing of both competitive and noncompetitive leases should begin during 1979 or, at the latest, 1980.

The granting of leases should serve as a catalyst in generating renewed interest in the geothermal potential of the state by industry. A renewed interest and commitment in the state by industry in conjunction with the accelerated assessment program conducted by the U.S. Geological Survey and the Washington Division of Geology and Earth Resources is expected to result in the orderly and timely assessment and development of the state's geothermal resources, but remains dependent upon the receipt of adequate funding by the state and federal agencies involved. 


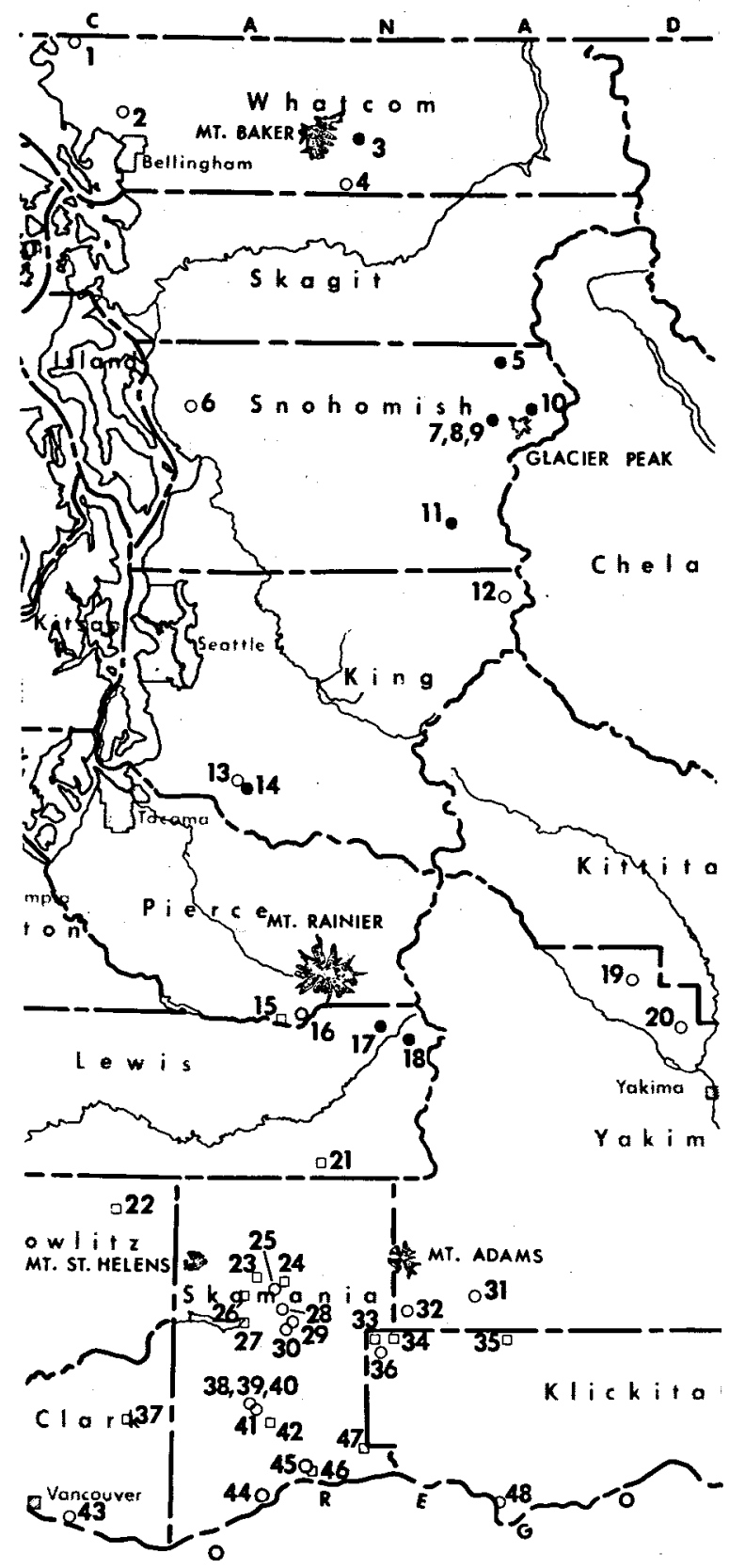

1. City of Blaine spring

2. Larabee Spring

3. Mount Baker hot spring

4. U.S. Forest Service spring

5. Sulphur hot springs

6. Edwards springs

7. Kennedy Hot springs

8. Upper Kennedy hot spring

9. Kennedy No. 3 spring

10. Gamma hot spring

11. Garland Mineral Springs

12. Scenic Hot Spring

13. Diamond Mineral Spring

14. Flaming Geyser well

15. Nisqually River

16. Longmire Springs

17. Ohanapecosh hot springs

18. Summit Creek Soda Spring

19. Malotte spring

20. Mulford spring

21. Cispus River

22. North Fork Toutle River

23. Clear Creek

24. Lewis River
25. Landslide spring

26. Muddy River

27. Pine Creek

28. Spring 72

29. Lonesome Sale Road spring

30. Spring 710

31. Bacon Creek spring

32. Gotchen Creek spring

33. Trout Lake Creek

34. White Salmon River

35. White Creek

36. Bear Creek spring

37. East Fork Lewis River

38. Iron Mike Spring

39. Bubbling Mike Spring

40. Little Iron Mike Spring

41. Little Soda Spring

42. Wind River

43. City of Vancouver spring

44. Bonneville hot spring

45. St. Martin Hot Springs

46. Wind River

47. Little White Salmon River

48. Leonardo springs

- Thermal springs, mineral springs, or cold springs with $\mathrm{Na}-\mathrm{K}-\mathrm{Ca}$ temperatures be low $100^{\circ} \mathrm{C}$.

Thermal or mineral springs with $\mathrm{Na}-\mathrm{K}-\mathrm{Ca}$ temperatures above $100^{\circ} \mathrm{C}$.

River water, all with $\mathrm{Na}-\mathrm{K}-\mathrm{Ca}$ temperatures below $100^{\circ} \mathrm{C}$.

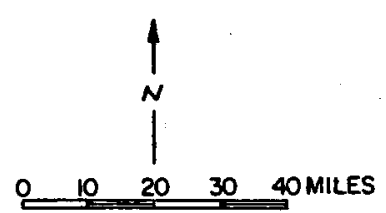

(Schuster ef al., 1978)

FIGURE 3 - Locations of chemically analyzed springs and rivers in the Cascade Range, Washington. 
The Cascade Range Geothermal Province

The abundant Tertiary and Quaternary volcanics and volcanic features of the Cascade Range of northern California, western Oregon, and western Washington indicate that this is one of the major geothermal provinces of the United States. The range trends north-south and extends the entire length of the State of Washington, thus forming the principal geothermal target area of the state.

Five major andesitic stratovolcanoes form the dominant topographic feature of the range in Washington and include Mount St. Helens, Mount Adams, Mount Rainier, Glacier Peak, and Mount Baker. Of possible equal importance to the stratovolcanoes is a series of volcanic centers composed predominantly of basalt. These volcanic centers, although not as physically imposing, may be much more abundant volumetrically, and possibly as important as centers of geothermal activity. The basaltic centers are the Indian Heaven fissure zone area, the King Mountain fissure zone area, and the Simcoe Mountains area. All of the basaltic centers are located in the southern part of Washington's Cascade Range. (Schuster et al., 1978)

Several of the stratovolcanoes have been historically active and the modern cone of Mount St. Helens is probably the product of the last one thousand years. Dates of less than 4,000 years have been established for some of the flows of the basaltic centers of the southern Cascades (Mullineaux and Cranda11, 1960).

Indications that hot rocks and perhaps magma still exist at depth are found in the form of several thermal and mineral springs (fig. 3 ), which tend to be associated with the stratovolcanoes, and fumeroles, which are found in the summit crater or on the flanks of the stratovolcanoes. Mount Baker experienced a dramatic increase in fumerolic activity in 1975 and the level of activity has remained relatively constant until the present although surges of increased activity have been experienced during this 3.5-year period. The 1975 estimates of the total heat flux. that would account for the observed snow and ice loss on Mount Baker was ca. 30 megawatts at 180 watts per square meter (Frank et al., 1977).

Chemical data for springs and selected rivers in the Cascade Range of Washington are in table 1. The sample locations are shown on figure 3.

The ionic concentrations, as presented in table 1, are in many cases suspected of being in error and resampling and analyses are now underway for the majority of the springs listed. In addition, the recent discovery of the importance of the ionic concentration of the Mg to the calculation of reservoir temperature by the $\mathrm{Na}-\mathrm{K}-\mathrm{Ca}$ method will have to be considered and could result in significant changes in the predicted $\mathrm{Na}-\mathrm{K}-\mathrm{Ca}$ temperatures in table 1 .

Reservoir temperatures calculated from the ionic concentrations of $\mathrm{Na}$, $\mathrm{K}$, and $\mathrm{Ca}$, as well as $\mathrm{SiO}_{2}$, are a valuable indication of actual reservoir temperature. The use of geothermometers, however, requires the making of several assumptions and is thus subject to many uncertainities. 
TABLE 1 - Chemical data for springs and rivers in the Cascade Range, Washington

\begin{tabular}{|c|c|c|c|c|c|c|c|c|c|c|c|c|c|c|c|c|c|c|}
\hline \multirow{3}{*}{$\begin{array}{l}\text { Map } \\
\text { no. }\end{array}$} & \multirow{3}{*}{ Name } & \multirow{3}{*}{ County } & \multirow{3}{*}{ Location } & \multirow{3}{*}{ 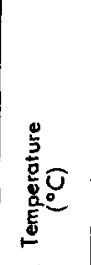 } & \multirow[b]{3}{*}{ 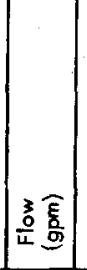 } & \multirow[b]{3}{*}{$\frac{T}{a}$} & \multirow{2}{*}{\multicolumn{6}{|c|}{ Ports per million }} & \multirow{3}{*}{ 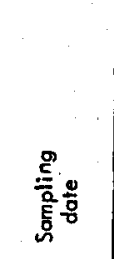 } & \multicolumn{3}{|c|}{ 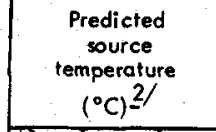 } & \multirow{3}{*}{ 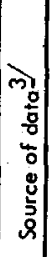 } & \multirow{3}{*}{ 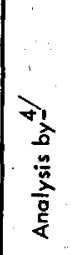 } \\
\hline & & & & & & & & & & & & & & & & & & \\
\hline & & & & & & & $\bar{U}$ & z & 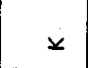 & ن & $\stackrel{\text { N }}{i n}$ & ב & & $\mathbf{z}$ & $\stackrel{D}{N}^{N}$ & $\stackrel{*}{0}$ & & \\
\hline 1 & City of Blaine spring.... & Whatcom & $S W_{2} 3,(40-1 E)$ & ....... & & 7.3 & 3.3 & 5.8 & 2.0 & 12 & 24 & & $4 / 7 / 49$ & 22 & 65 & 300 & 1 & \\
\hline 2 & Larabee Spring............. & ...do... & $N W \frac{1}{4} 36,(39-2 E)$ & $\ldots \ldots$ & $\cdots$ & 7.3 & 22 & 18 & 3.0 & 23 & 19 & $\ldots$. & $4 / 7 / 49$ & 42 & 55 & 250 & 1 & \\
\hline \multirow[t]{4}{*}{3} & Mount Baker hot spring.... & ...do... & $N W \neq S W \neq 20,(38-9 E)$ & 42 & 7 & 8 & 108 & 165 & 10.0 & 7.9 & 140 & 0.4 & $\ldots \ldots \ldots$ & is $s 2^{*}$ & 157 & 139 & 3 & Uw \\
\hline & ....................... & ...do... & .........do........... & $\sim 38$ & $6-8$ & 8.3 & 128 & 150 & 13 & 0.8 & …… & ..... & $10 / 3 / 73$ & $\ldots$. & $\ldots$ & 173 & 5 & DOE \\
\hline & ............do............ & ...do... & .........do.......... & ..do.. & .do. & 7.7 & 146 & 158 & 10 & 2 & -1 & 0.38 & ...do... & $175^{\star}$ & $\cdots$ & 142 & 611 & USBM \\
\hline & ............................... & ...do... & ..........do........... & ..do.. & .do. & 8.4 & 109 & 154 & 7.7 & 16.6 & 94 & 0.80 & ...do... & $146^{*}$ & 134 & 124 & $6 / 1$ & UN \\
\hline 4 & U.S. Forest Service spring. & ...do... & $N W \neq 25,(37-8 E)$ & 12 & .... & 7.3 & 4.0 & 6.4 & 2.4 & 8.4 & 23 & $\ldots \ldots$ & $10 / 27 / 54$ & 45 & 64 & 300 & 1 & $\ldots \ldots$ \\
\hline \multirow[t]{4}{*}{5} & Sulphur hot springs ........ & Snohomish & $N W 1719,(32-13 E)$ & $\sim 30$ & $1-2$ & 7.8 & 54 & 103 & 1.7 & 1.0 & 75 & 0.2 & $7 / 7 / 62$ & $135^{\star}$ & 122 & 180 & 21 & USGS \\
\hline & ............................. & ...do... & .........do........... & 37 & 4 & 8 & 52 & 108 & 2.4 & N.D.6 & 120 & 0.1 & ........ & $\ldots \ldots$ & 148 & $<80$ & 3 & uw \\
\hline & ...........do............. & ...do... & ..........do........... & 39 & 2 & 8.6 & 100 & 96 & 2 & $<0.2$ & 0 & $\ldots \ldots$ & $7 / 26 / 71$ & $\ldots .$. & $\ldots$ & $<80$ & 4 & USBM \\
\hline & ............................ & ...do... & .........do........... & $\cdots \cdots$ & $1-2$ & 8.5 & 55 & 103 & 1.4 & 12 & 66 & 0.31 & $10 / 3 / 73$ & 49 & 114 & 180 & 6 & UN \\
\hline 6 & Edwards springs $\ldots \ldots \ldots$. & ...do... & $S W_{2}^{\prime} 24,(31-4 E)$ & 10 & $\ldots$ & 7.5 & 3.6 & 5.6 & 1.4 & 9.0 & 31 & ..... & $9 / 2 / 44$ & 29 & 76 & 300 & 1 & $\ldots \ldots$ \\
\hline \multirow[t]{6}{*}{7} & Kennedy Hot springs 7 .. & ...do... & 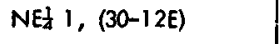 & $\sim 30$ & $3-5$ & 7.7 & 643 & 655 & 64 & 37 & 136 & 3.3 & $7 / 30 / 61$ & $199 *$ & 155 & 187 & 2 & USGS \\
\hline & 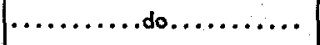 & ...do... & .........do.......... & 34 & $\ldots$ & 7 & 612 & 808 & 67.8 & 228 & 380 & 3.7 & $\ldots \ldots \ldots$ & $177^{*}$ & 227 & 168 & 3 & uw \\
\hline & $\ldots \ldots \ldots \ldots$ do & ...do... & ..........do.......... & 37 & 4 & 6.5 & 676 & 660 & 75 & 73 & 0 & $\ldots$. & $7 / 26 / 71$ & $201 *$ & $\cdots$ & 202 & 4 & USBM \\
\hline & n.........do................ & ...do... & ..........do........... & $\ldots \ldots$ & $6-8$ & 7.1 & 28 & 600 & 85 & 125 & $\ldots \ldots$ & $\ldots$. & $10 / 3 / 73$ & $207^{*}$ & .. & 228 & 5 & DOE \\
\hline & (n..........do............. & ...do... & .........do........... & $\ldots \ldots$ & $6-8$ & 7.4 & 730 & 688 & 75 & 192 & $\sim 0.5$ & 3 & $10 / 3 / 73$ & $190^{*}$ & $\cdots$ & 197 & 6 & USBM \\
\hline & ....................... do & ...do... & .........do.......... & $\ldots \ldots$ & $6-8$ & 8.4 & 612 & 660 & 71.2 & 193 & 167 & 5.8 & $10 / 3 / 73$ & $189 *$ & 167 & 196 & 61 & UN \\
\hline 8 & Upper Kennedy hot spring?. & ...do... & ..........do.......... & 38 & 4 & 6.6 & 681 & 626 & 79 & 69 & 2) & $\ldots \ldots$ & $7 / 26 / 71$ & $207^{*}$ & 60 & 213 & 4 & USBM \\
\hline 9 & Kennedy No. 3 spring .... & ...do... & .........do........... & $\sim 21$ & $2-3$ & 8.7 & 500 & 562 & 58.6 & 157 & 123 & 4.7 & $10 / 3 / 73$ & $186^{*}$ & 149 & 192 & 6. & UN \\
\hline 10 & Gamma hot spring .......... & ...do... & $\sim$ SE, cor. $24,(31-13 E)$ & $\sim 60$ & $3-4$ & 7.9 & 728 & 491 & 77 & 47 & 150 & 2.6 & $8 / 28 / 62$ & $220^{*}$ & 160 & 243 & 2 & USGs \\
\hline \multirow[t]{2}{*}{11} & Garland Mineral Springs 8 .. & ...do... & $N W d 25,(28-11 E)$ & 21 & .... & 6 & 2671 & 1592 & 130 & 336 & 120 & 7.5 & $\ldots \ldots \ldots$ & $184^{*}$ & 148 & 167 & 3 & uw \\
\hline & ........................... & ...do... & .........do........... & 7 & 25 & 6 & 461 & 358 & 27.9 & 90 & N.D. & 1.4 & $\therefore \ldots \ldots$ & $167^{*}$ & ... & 162 & 3 & uw \\
\hline 12 & Scenic Hot Spring ........ & King & Sec. $28(26-13 E)$ & 10 & 30 & 5 & N.O. & N.D. & 1.2 & 14 & N.D. & N.D. & $\ldots \ldots \cdots$ & $\ldots \ldots$ & ... & $\cdots$ & 3 & UW \\
\hline 13 & Diamond Mineral Spring... & ...do... & Sec. 21, (21-6E) & 11 & $\cdots$ & 8 & 1574 & 1280 & 5.5 & 118 & N.D. & N.D. & & $92^{*}$ & $\ldots$ & $(80$ & 3 & uw \\
\hline 14 & Flaming Geyser well ..... & ...do.... & SEd 27, (21-6E) & 12.5 & .... & 8.5 & 5600 & 4640 & 34.9 & 54 & 90 & 0.4 & .......... & $121^{*}$ & 132 & $<80$ & 3 & uw \\
\hline 15 & Nisqually River ........... & Pierce & SW $34,(15-7 E)$ & 8 & .... & 7.2 & 2 & 6.4 & 4.9 & 2.3 & 73 & $\ldots .$. & $9 / 6 / 72$ & 93 & 120 & 300 & 4 & DOE \\
\hline \multirow[t]{2}{*}{16} & Longmire Springs .......... & ...do... & Near SE.cor. $29,(15-8 E)$ & 21 & $\ldots$ & 6 & 615 & 402 & 37.2 & 298 & 170 & 1.8 & ........ & 99 & 168 & 180 & 3 & UW \\
\hline & ............do.......... & ...do... & ..........do.......... & 22 & 0 & 7.4 & 1657 & 487 & 41 & 492 & 0 & 2 & $10 / 18 / 73$ & 93 & $\ldots$ & 170 & 6 & USBM \\
\hline \multirow[t]{3}{*}{17} & Ohanapecosh hot springs?.. & Lewis & $N W 14,(14-10 E)$ & 40 & 60 & 7 & 869 & 981 & 50.9 & 85 & 80 & 3.3 & ......... & $164^{*}$ & 125 & 127 & 3 & uw \\
\hline & .......................... & ...do... & .........do........... & 49 & 3 & 7.7 & 915 & 935 & 50 & 64 & $\sim 1.5$ & 3 & $10 / 18 / 73$ & ..... & $\ldots$ & 129 & 6 & USBM \\
\hline & ............, do........., & ...do... & .........do........... & ..do.. & .do. & 7.9 & 867 & 914 & 55.3 & 77 & 89 & 4.7 & $10 / 18 / 73$ & $172^{*}$ & 131 & 138 & 6 & UN \\
\hline \multirow[t]{3}{*}{18} & Summir Creek Soda Spring?! & ...do... & Neor center $18,(14-11 E)$ & 13 & $|\cdots|$ & 6 & 1552 & 1790. & 86.7 & 278 & 170 & 5.9 & ........ & $161 *$ & 168 & 122 & 3 & uw \\
\hline & ...........do.............. & ...do... & .........do.......... & 12 & 3 & 7.7 & 2840 & 1690 & 86 & 257 & 0 & 5 & $10 / 18 / 73$ & $163^{*}$ & $\ldots$ & 126 & 6 & USBM \\
\hline & {$[\ldots \ldots \ldots, \ldots$ do $\ldots, \ldots, \ldots$} & ...do... & .........do........... & ...do.. & .do. & 7.9 & 1404 & 1770 & 97.6 & 247 & 100 & 7.5 & $10 / 18 / 73$ & $168^{*}$ & 138 & 132 & 6 & UN \\
\hline 19 & IMaloste spring ............ & Yakima & SEA 32, (16-17E) & 17 & 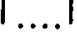 & $7.7 \mid$ & $\mid 1.8$ & 17 & 4.3 & 12 & 53 & & $11 / 19 / 48$ & 64 & 103 & b300l & 11 & \\
\hline
\end{tabular}




\begin{tabular}{|c|c|c|c|c|c|c|c|c|c|c|c|c|c|c|c|c|c|c|}
\hline 20 & |Mulford spring ............. & ...do... & $S W \neq 3,(14-18 E)$ & 15 & $\cdots \cdot$ & 7.6. & 9.1 & 13 & 5.8 & 32 & 66 & $\cdots \cdots$ & $11 / 19 / 48$ & 51 & 114 & $\left.\right|^{2300}$ & 11 & \\
\hline 21 & Cispus River .............. & Lewis & NEL $23,(11-8 E)$ & 9 & .... & 7.4 & 3 & 4.4 & 1.3 & 1.2 & 28 & $\cdots$ & $9 / 6 / 72$ & 60 & 72 & 1300 & 4 . & DOE \\
\hline 22 & North Fork Toutle River ... & Cowlitz & SEA 33, (10-3E) & 11 & $\ldots$ & 7.5 & 7 & 15 & 1.2 & 1.5 & 32 & .... & $9 / 8 / 72$ & 66 & $\pi$ & 163 & 4 & DOE \\
\hline 23 & Clear Creek .............. & Skomonia & Sec. $20,(B-7 E)$ & 12 & .. & 7.1 & 4 & 3.6 & 0.4 & 1.7 & 21 & & $9 / 8 / 72$ & 22 & 60 & 198 & 4 & DOE \\
\hline 24 & Lewis River .............. & ...do... & Sec. $25,(8-7 E)$ & 10 & .. & 7.2 & 2 & 4.2 & 1.0 & 1.0 & 21 & & $9 / 8 / 72$ & 56 & 60 & $>300$ & 4 & DOE \\
\hline 25 & Londslide spring ........... & ...do... & $5 W \neq 34,(8-7 E)$ & 5.5 & .... & 6.9 & $<1$ & 3.4 & 0.2 & 1.3 & 9 & .... & $8 / 30 / 72$ & 10 & +40 & 137 & 4 & DOE. \\
\hline 26 & Muddy River .............. & ..do... & NWI 1, (7-6E) & 9 & .. & 7.4 & 6 & 10.3 & 0.7 & 1.7 & 30 & & $9 / 8 / 72$ & 45 & 75 & 145 & 4 & DOE. \\
\hline 27 & Pine Creek .............. & ...do... & $S W \frac{1}{4} 24,(7-6 E)$ & 8 & ... & 7.5 & 7 & 11.8 & 1.8 & 1.1 & 56 & $\cdots$ & $9 / 8 / 72$ & 82 & 106 & 238 & 4 & DOE \\
\hline 28 & Spring $72 \ldots \ldots \ldots \ldots$....... & ...do... & $S E 213,(7-7 E)$ & 4 & & 6.9 & 1 & 3.4 & 0.6 & 1.0 & 19 & & $8 / 17 / 72$ & 40 & 55 & 260 & 4 & DOE \\
\hline 29 & Lonesome Sale Road spring . & ...do... & $N W \downarrow 30,(7-8 E)$ & 4.5 & & 7.2 & 6 & 6.0 & 0.6 & 2.0 & 24 & & $8 / 17 / 72$ & 33 & 65 & 188 & 4 & DOE \\
\hline 30 & Spring $710 \ldots . . . . . . .$. & ...do... & NEt 36, (7-7E) & 4 & ... & 7.1 & 1 & 2.6 & 0.3 & 1.5 & 15 & $\ldots$ & $8 / 17 / 72$ & 15 & 50 & 204 & 4 & DOE \\
\hline 31 & Bocon Creek spring ..... & Yakimo & SEd $1,(7-12 E)$ & 6 & & 6.9 & 1 & 59 & 1.2 & 0.7 & 17 & & $9 / 16 / 72$ & 97 & 52 & 680 & 4 & DOE \\
\hline 32 & Gotchen Creek spring..... & ...do.... & $S W+18,(7-11 E)$ & 3 & & 6.9 & 1 & 3.4 & 1.5 & 0.4 & 17 & & $9 / 15 / 72$ & 85 & 52 & 1300 & 4 & DOE \\
\hline 33 & Trout Lake Creek ........... & Klickitat & NEE⿱亠䒑 $8,(6-10 E)$ & 12 & & 7.4 & 1 & 4.4 & 0.7 & 1.4 & 17 & $\cdots$ & $9 / 7 / 72$ & 55 & 52 & 244 & 4 & DOE \\
\hline 34 & White Salmon River ........ & ...do... & $5 W_{4}^{1} 11,(6-10 E)$ & 8 & & 7.2 & 2 & 4.2 & 1.7 & 1.3 & 32 & & $9 / 7 / 72$ & 66 & $\pi$ & 3300 & 4 & DOE \\
\hline 35 & White Creek............ & ...do... & $5 W+11,(6-13 E)$ & 14 & $\ldots$ & 8.1 & 15 & 10.8 & 1.5 & 3.3 & 21 & & $9 / 7 / 72$ & 54 & 60 & 225 & 4 & DOE. \\
\hline 36 & Bear Creek spring ....... & ...do... & SE $20,(6-10 E)$ & 13 & & 7.1 & 1 & 5.4 & 0.6 & 1.7 & 24 & & $8 / 25 / 72$ & 35 & 65 & 198 & 4 & DOE \\
\hline 37 & Eosf Fork Lewis River ...... & Clark & $N W \neq 13,(4-3 E)$ & 13 & & 7.2 & 5 & 6.2 & 0.2 & 3.3 & 17 & & $9 / 8 / 72$ & 2 & 52 & 93 & 4 & DOE \\
\hline 38 & Iron Mike Spring 8 . ....... & Skamania & Sec. $31,(5-7 E)$ & 10 & $\cdots$ & 7 & 318 & $211:$ & 6.2 & 192 & 40 & 0.4 & ......... & 45 & 90 & 89 & 3 & uw \\
\hline 39 & Bubbling Mike Spring 8 & ...do... & .........do.... & 8.5 & & 6.5 & 276 & 176 & 5.1 & 154 & 50 & 0.3 & & 43 & 100 & 88 & 3 & uw \\
\hline 40 & Little Iron Mike Spring 8 .. & ...do... & .........do........ & 10 & & 6.5 & 561 & 404 & 9.6 & 309 & N.D. & 0.8 & ........ & 55 & $\ldots$ & $<8$ & 3 & uw \\
\hline 41 & Little Sodo Spring ......... & ...do... & SEd 5, (4-7E) & 8 & $\ldots$ & 6. & 36 & 28 & 13.6 & 46 & N.D. & N.D. & $\ldots \ldots \ldots$ & $\pi$ & $\ldots$ & $>300$ & 3 & uw \\
\hline 42 & Wind River ............ & ...do... & $N W \pm 15,(4-7 E)$ & 13 & $\ldots$ & 7.2 & 4 & 4.0 & 0.5 & 1.8 & 24 & & $9 / 7 / 72$ & 27 & 65 & 212 & 4 & DOE \\
\hline 43 & Cily of Vancouver spring .. & Clark & $S W \frac{1}{4} 33,(2-2 E)$ & 10 & & $\ldots$ & 2.9 & 4.2 & 5.6 & 15 & 50 & & $5 / 17 / 49$ & 53 & 100 & $>300$ & 1 & $\ldots \ldots$ \\
\hline 44 & Bonneville hot spring ..... & Skamanio & Sec. 16, (2-7E) & 32 & 20 & 9.5 & 151 & 126 & 1.5 & 42 & N.D. & N.D. & ......... & 31 & $\cdots$ & $<80$ & 3 & uw \\
\hline 45 & St. Mortin Hot Springs .... & ...do... & SE. cor. $21,(3-8 E)$ & 49 & $\cdots$ & 7 & 636 & 291 & 0.2 & 104 & N.D. & 0.2 & ......... & 60 & $\ldots$ & $<80$ & 3 & Uw \\
\hline 46 & Wind River ............... & ...do... & $5 W \$ 22,(3-8 E)$ & 14 & $\cdots$ & 7.5 & 4 & 7.4 & 0.8 & 1.7 & 30 & & $9 / 7 / 72$ & 45 & 75 & 196 & 4 & DOE \\
\hline 47 & Little White Salmon River.. & ...do... & $N W \neq 1,(3-9 E)$ & 8 & $\ldots$ & 7.2 & -2 & 6.0 & 1.2 & 1.3 & 58 & ... & $9 / 7 / 72$ & 59 & 108 & 228 & 4 & DOE \\
\hline 48 & Leonardo springs ........ & Klickitat & $N W \pm 21,(2-13 E)$ & 14 & .. & $\ldots$ & 5.0 & 7.8 & 2.1 & 22 & 48 & & $7 / 29 / 30$ & 27. & 98 & $>300$ & 1. & $\therefore \cdots$ \\
\hline
\end{tabular}

V Locations by legal land description ore obbrevioted; for exomple, SWI 3, (40-1E) written in full would be southwest quarter of section 3, township 40 north, range 1 cost.

2/ Na-K-Ca source lemperatures were colculated using the formula $\log \left(\frac{\mathrm{Na}}{\mathrm{K}}\right)+\beta \log \left(\frac{\sqrt{\mathrm{C}_{0}}}{\mathrm{Na}_{\mathrm{a}}}\right)=\frac{1647}{273++_{0} \mathrm{C}}-2.24$, where $\mathrm{Na}, \mathrm{K}$, and Ca concontrations ore expressed in molality, $s$ is either $4 / 3$ or $1 / 3$, and to $C$ is the predicted source temperature in degrees $C_{e}$ lsius. A source temperature is calculated using $A=4 / 3$. If this temperature is greater thon $100^{\circ} \mathrm{C}$, source Temperature is recalculated using $\rho=1 / 3$ (Founnier and Truesdell, 1973, 1974).

$\mathrm{SiO}_{2}$ source remperatures ore estimoted from eurve A of Fournier and Truesdell (1970), which assumes cooling entirely by heat conduction ond equilibrium with quartz.

$\mathrm{No} / \mathrm{K}$ source temperatures are estimated from curve $G$ of $A$. J. Ellis White, 1970).

3/ $1=$ Van Denburgh and Santos, 1965; $2=$ Tobor and Crowder, 1969; $3=$ Compbell and others, 1970; $4=$ Division of Geology and Earth Resources files, 1972; $5=$ Division of Geology and Earth Resources Files, 1973; $6=$ Division of Geology and Earth Resources Files, 1974.

4/ UW $=$ University of Woshington; DOE = Woshington State Department of Ecology; USBM $=$ United States Bureau of Mines, Bartlesville, OK; UN $=$ University of Nevada, Desert Reseorch Institute, Boulder Ciry, NV; USGS $=$ Uhited States Geological Survey.

5/ Rredicted temperatures morked by an asterisk (") were calculated using $A=1 / 3$. Unmarked Na-K-Co temperatures were calculated using $A=4 / 3$, see footnote 2 .

6/ Not detecled.

I/. Springs with extensive calcareous tufa deposits.

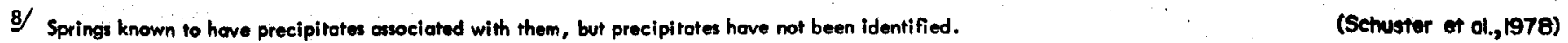


For purposes of geothermometry it is assummed that certain chemical reactions take place involving the water and the reservoir rock within which the water is held or through which the water passes. The rate of reaction is temperature dependent and, therefore, ionic concentrations in the solute, assumming equilibrium conditions, should be a reflection of temperature. However, the exact reactions which take place are unknown due to several factors. Of these factors, original chemical composition of the water, chemical makeup of the reservoir rock, and length of residence of the water in the reservoir are unknown. Also unknown is the rate at which additional reactions take place as the water rises toward the surface and the degree of mixing that occurs between the hydrothermal fluids and water encountered nearer the surface. Due to the number of unknowns, the accuracy of geochemically estimated reservoir temperatures is difficult to assess. Reasonable agreement among the various geothermometers would tend to increase the chance that the estimate is reliable.

Despite the shortcomings of geothermometry and the danger of giving too much credence to any one analysis, geothermometry can and does. provide useful information about reservoir temperatures. This is especially true when regional patterns are considered or where spring systems allow for large numbers of related springs to be analyzed.

Spring geochemistry and calculated reservoir temperature comprise the most complete data available concerning the geothermal resources of the Cascade Range and were heavily relied upon in this report in an attempt to predict the eventual utilization of resources that might be encountered.

of the six sites in the Cascade Range that were selected for consideration, three of the sites, Mount St. Helens, Indian Heaven, and Kennedy Hot Springs, were chosen because of their status as KGRA's. The remaining three sites, Mount Adams, Mount Rainier, and Mount Baker, were selected because of their location in PGRA's and because of strong geological evidence of recent volcanism and/or thermal activity. 
MOUNT ADAMS PGRA 


\section{FIGURE 4 - GEOTHERMAL LAND CLASSIFICATION MAP \\ MOUNT ADAMS PGRA}

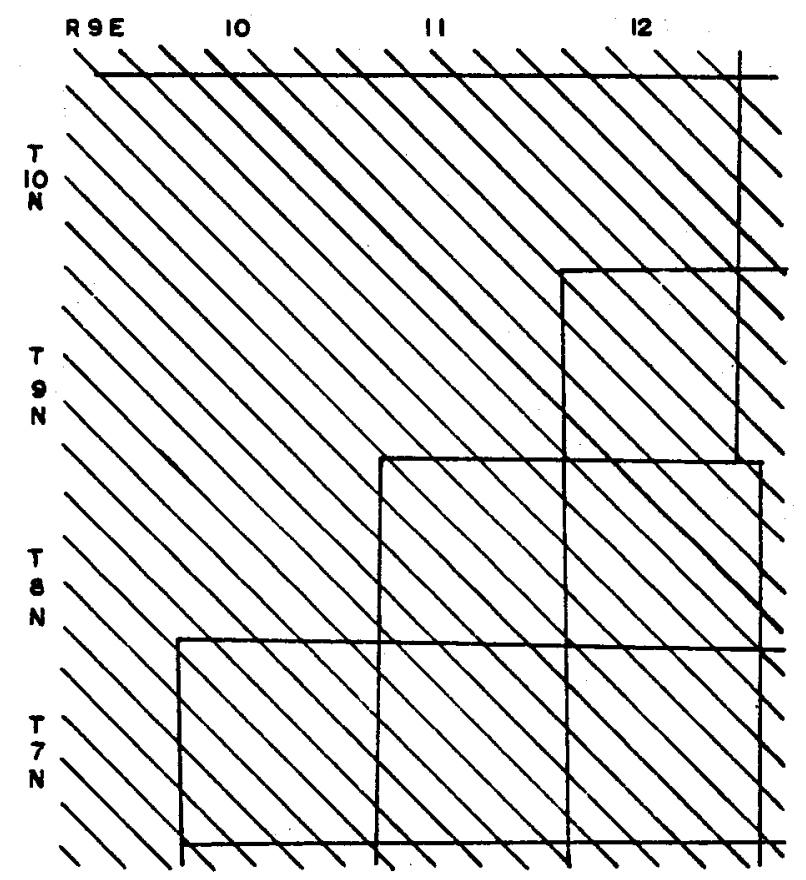

LEGEND LANDS VAluable PROSPECTIVELY FOR
GEOTHERMaL RESOURCES

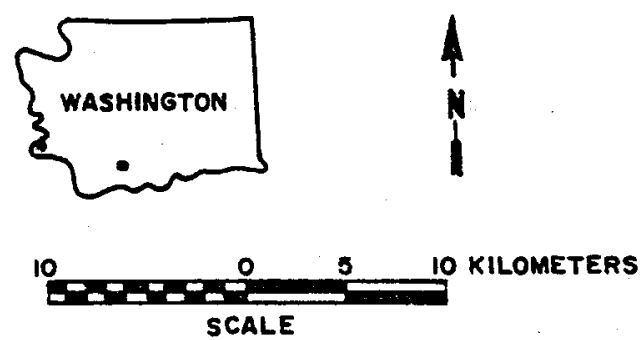

Base mop: U.S Geological Survey Geothermal Land Classification Map, Washington, 1974 


\section{MOUNT ADAMS PGRA}

\section{Introduction}

The Mount Adams PGRA is located in the southwest portion of the state. The area is ca. $45 \mathrm{~km}$ (28 miles) north of White Salmon, Washington. The eastern part of the study area is within the Yakima Indian Reservation and under the jurisdiction of the Yakima Nation. The western part is comprised of Gifford Pinchot National Forest lands and the Mount Adams Wilderness Area.

The rectilinear location of the peak of Mount Adams is SEl/4 sec. 1, T. 8 N., R 10 E.

The study area includes some 368,690 acres. Of this amount, ca. 138,240 acres are within the Yakima Indian Reservation ca. 34;560 acres are in the Mount Adams Wilderness Area, ca. 161,280 acres are in the Gifford Pinchot National Forest, ca. 23,040 acres are under the jurisdiction of the state, and ca. 11,520 acres are privately owned.

The study area has been classified as a PGRA (Potential Geothermal Resource Area) by the U.S. Geological Survey. The area has been so classified because of its location in the Cascade Range and because of the presence of Mount Adams, a major stratovolcano within the PGRA. The area is not, however, considered to be one of the top four prospects in the state.

There are several reasons for not classifying the Mount Adams PGRA as one of the state's top prospects. Among these, lack of recent volcanic activity, and land status are probably most important. Mount Adams has not received as much attention by geologists as some of the other stratovolcanoes in the state and is therefore less well known. This lack of attention can be attributed to the absence of historic volcanic activity and the reduced risk which the mountain is perceived to present.

The study area contains no permanent population centers. The closest towns are Troutlake and Glenwood, which lie to the south. White Salmon, with a 1977 population of 1,715 , lies ca. $45 \mathrm{~km}$ ( $28 \mathrm{miles}$ ) from the mountain. The population density of the entire region is below 30 per square kilometer. Timber production and recreation are the two primary land uses. Topographically, the entire area is one of considerable relief with elevations reaching $3,742 \mathrm{~m}$. $(12,277 \mathrm{ft}$. $)$.

Energy consumption in the study area, as well as in the potential service area, is low due to the lack of industry and low population density. Present energy uses are supplied by electricity, oil, and gas.

Energy needs, which could be met by geothermal resources, are at present impossible to assess. Little geological information is available, and geochemical and geophysical information is almost completely lacking in this area. Heat flow drilling, which was carried out by the Washington Division of Geology and Earth Resource to the southeast in the Indian Heaven KGRA (Known Geothermal Resource Area), was inconclusive and at such a distance from the Mount Adams PGRA to be of little use. 
In general, estimates of the potential geothermal resources of the region point to temperatures below those required for electrical generation, but well within the range needed for direct utilization. Direct utilization of hydrothermal water for space heating, greenhouse use, and lumber drying has been demonstrated to be economically competitive with other energy sources at Klamath Falls, Oregon; Boise, Idaho; and Reykjavik, Iceland. However, low population densities and long transmission distances could be an overriding factor and will have to be carefully considered together with the quality and quantjty of any resource which may be discovered.

The U.S. Geological Survey, in cooperation with the Washington Division of Geology and Earth Resources, is presently engaged in a comprehensive 3- to 5-year study of the geothermal potential of the Cascade Range and will naturally evaluate the potential of Mount Adams as part of this study. At what point in the program Mount Adams will be the focus of study has not yet been determined.

Land status is perceived as nonconducive to geothermal exploration and development. Portions of the PGRA which fall within the Yakima Indian Reservation or the Mount Adams Wilderness Area are not open to private leasing by provisions of the Geothermal Steam Act of 1970 (Appendix I). Lands under the jurisdiction of the Yakima Indian Nation can, however, be developed by the Yakima Nation, or the lands could be leased by the tribal council for the purpose of geothermal exploration and development by private entities.

To date-7ittle interest has been shown in the study area beyond the filing of lease applications with BLM, and private companies are not likely to invest in the area until such time as leasing becomes possible. of the total number of acres in the PGRA, only those managed by the forest service are available for leasing under provisions of the Geothermal Steam Act of 1970 (Appendix I). Lands within the Yakima Indian Reservation and the Mount Adams Wilderness Area are excluded. Leasing of reservation lands by the Yakima Nation's tribal council could, however, take place.

The leasing of lands within the Gifford Pinchot National Forest by BLM can take place only after the completion and acceptance of an environmental statement considering the potential impact of geothermal exploration and development is completed by the forest service.

The preparation of such a statement can take from 2 to 3 years and will be dependent upon the availability of funding. Such a statement is now in preparation.

After the acceptance of an environmental statement, leasing and exploration can take place. A thorough assessment program utilizing geologic, geochemical, and geophysical techniques could take another 2 to 3 years, and it would be only after the completion of such an assessment program that the decision to development could be made. Thus, geothermal resources could not be expected to be contributing to the energy budget of the state until at least the latter half of the 1980's. 


\section{SITE DATA SUMMARY}

SITE: Mount Adams PGRA

..Physical Reservoir Data

..Temperature ${ }^{\circ} \mathrm{C}$

Surface: Approximately $65^{\circ} \mathrm{C} .\left(150^{\circ} \mathrm{F}\right)$ (Fowler 1935)

Subsurface: No information is available.

..Total Dissolved Solids (PPM): No information is available

..Type of Overlying Rock: Andesite flows interbedded with pyroclastics (Huntting et az. 1961).

..Estimated Depth to Top of Reservoir (meters): No estimate is possible.

..Site Land Status

$\begin{array}{lllll} & \text { FED. } & \text { STATE } & \text { PRIVATE } & \text { OTHER } \\ \text { Total Acres } & 195,840 & 23,040 & 11,520 & 138,240 \\ \text { Total Acres Leased } & \text { None } & \text { None } & \text { None } & \text { None }\end{array}$

..Geothermal Development Status: No geothermal development has taken place on or around Mount Adams, and no known development is planned for the area.

..Local and State Attitude Toward Geothermal Development: At the present time, the Washington State Department of Natural Resources and the Washington State Energy Office are in the process of developing a statewide plan for geothermal assessment and development. The Mount Adams area is one of several areas of interest in the state. The attitude of the Yakima Indians toward development in the parts of the area which lie within the reservation is not known.

..Land Use and Population: Population levels in the vicinity of Mount Adams are very low. No major city is found within a 50-mile radius of the mountain. (U.S. Forest Service, Gifford Pinchot National Forest Map, 1976; Washington State Highway Commission Map, 1975)

Land use is restricted in the immediate vicinity of the mountain by the presence of the Mount Adams Wilderness Area from the crest and to the west, and the Yakima Indian Reservation to the east. Outside the Wilderness Area to the west, north, and south lies the Gifford Pinchot National Forest. Within the forest the principal land uses are recreation and timber production. (U.S. Forest Service, Gifford Pinchot National Forest Map, 1976)

. Comments and Critical Is sues: The areas of the Mount Adams PGRA that fall within the Mount Adams Wilderness Area and those areas within the Yakima Indian Reservation are excluded from leasing under provisions of the Geothermal Steam Act of 1970 (Appendix I). Development on national 
forest lands will be extremely environmentally sensitive and cannot commence until an EIS is prepared in regard to geothermal. leasing and development. In addition, a thorough geologic assessment is needed before the area can be seriously considered. 
..Latitude: $46^{\circ} 12^{\prime} \mathrm{N}$.

...Longitude: $121^{\circ} 29^{\prime} \mathrm{E}$.

..Rectilinear: T. 8N., R. $10 \mathrm{E}$.

(Mt. Adams East quadrangle, 7.5-minute series, 1970; Mount Adams West quadrangle 7.5-minute series, 1970)

..County: Yakima

..Adjacent Counties: Skamania, Klickitat, and Lewis. (Washington State Highway Commission Map, 1975)

..Topography: The area is in the high Cascades with elevations up to $3,742 \mathrm{~m}(12,276 \mathrm{ft}$.$) . Much of the area is covered by steep ridges and$ deep canyons. Numerous glaciers are found on the mountain and flow down to approximately $2,200 \mathrm{~m}(7,200 \mathrm{ft}$. $)$. To the west of the mountain are several alpine lakes. To the east, the area flattens out as the high lava plateau is reached (Mount Adams East quadrangle, 7.5-minute series, 1970; Mount Adams West quadragle, 7.5-minute series, 1970).

..Present Land Use: Land use is restricted in the immediate vicinity of the mountain by the presence of.the Mount Adams Wilderness Area from the crest and to the west, and the Yakima Indian Reservation to the east. Outside the wilderness area to the west, north, and south lies the Gifford Pinchot National Forest. Within the forest the principal land uses are recreation and timber production (U.S. Forest Service, Gifford Pinchot National Forest Map, 1976)

.. Future Land Use Plans: It is expected that timber production and recreation will remain the dominant land uses on national forest lands. Within the boundaries of Mount Adams Wilderness Area, land use is restricted to recreation. Future land use on the Yakima Indian Reservation will be determined by the tribal council and it is not known at this time whether geothermal development will take place on the reservation.

..Aesthetics: This is an area of very high aesthetic value. The aesthetic and wilderness experience is of paramount value to visitors to the Mount Adams Wilderness Area as it is to visitors to the surrounding national forest lands. The area possesses numerous glaciers, glacial lakes, streams, waterfalls, and areas of geologic interest. The area is reached by numerous trails and is crossed by the Pacific Crest Trail (U.S. Forest Service, Gifford Pinchot National Forest Map, 1976)

..Historical/Archaelogical Significance: The Mount Adams area contains no known archaelogical sites or areas of historical significance as included in the National Register of Historical Places (Odegaard, 1976). The eastern part of the area, however, lies within the boundaries of the Yakima Indian Reservation and the mountain itself has spiritual significance to the Indian population. 
GEOLOGICAL/GEOPHYSICAL DESCRIPTION

.Geological Description: Mount Adams, with an elevation of $3,744 \mathrm{~m}$ $(12,300 \mathrm{ft}$.$) , is a composite volcanic cone that has been inactive in$ historic time. It is built chiefly of andesite lava flows, but includes interbedded layers of volcaniclastic debris.

The oldest rocks include a thick succession of deformed and altered volcaniclastic material interbedded with lava flows. Tuff breccia is dominant and occurs in massive 3 to $8 \mathrm{~m}$ thick beds. Volcanic wacke, volcanic arenite, and volcanic siltstone are interstatified with the tuff breccia.

Yakima Basalt underlies most of the southeast half of Mount Adams and most of the Quaternary olivine basalts south of the volcano.

The youngest lavas on the lower slopes of the mountain are several fresh, blocky flows that lie on the northwest, northeast, east, and south flanks. Most were extruded from vents near the base of the main cone of Mount Adams.

Three separate eruptive vents seem to comprise the main cone of Mount Adams: The three vents are located on a line that trends approximately $\mathrm{N}$. $18^{\circ} \mathrm{W}$, and their position may be fault controlled.

Evidence for a major fault beneath Mount Adams is provided by a linear, east-facing scarp. The south end of the scarp lies in the of NE 1/4 NE $1 / 4 \mathrm{sec}$. 9, T. $7 \mathrm{~N} ., \mathrm{R} .11 \mathrm{E}$., and can be traced $3 \mathrm{~km}$ to the SE 1/4 sec. 32, T. 8 N., R. $11 \mathrm{E}$. The scarp is in places 3 to $10 \mathrm{~m}$ high and has a trend of $\mathrm{N}, 22^{\circ} \mathrm{W}$. If the fault and the vents do lie along a common fault, then the fault is at least $10 \mathrm{~km}$ long and is a major structural feature in the area (Hopkins, 1976).

Glacial deposits, representing three separate episodes of glacier expansion, in the Mount Adams area are identifiable. They are, from oldest to youngest, the White Salmon, McDonald Ridge, and Big Muddy Creek drifts (Hopkins, 1976).

The Holocene activity of Mount Adams consists of lava flows of up to 6.5 $\mathrm{km}$ in length from flank eruptions, the construction of parasitic tephra cones, and one large lahar (Hopkins, 1976).

The existence of fumaroles on Mount Adams has been common knowledge among mountaineers for many years, evidently based upon the oftenreported odor of $\mathrm{H}_{2} \mathrm{~S}$ in the summit area. The earliest reports were made in 1917 by Judge Fred $W$. Stadter, who observed a group of steam vents west of the summit and less than 1,000 feet below the summit, in a canyon to the south of the so-called west summit and above White Salmon Glacier (Moxham, 1970).

Fowler (1935) reports great quantities of hydrogen sulphide gas issue daily from the rocks of the summit. He reports that by actual experimentation the gas was found to issue from nearly every crevasse, and the ice and snow at the summit is inlain by a layer of sulfur. Fowler 
(1935) also reports steam in very small amounts issues. from one area on South Is land. The temperature was estimated to be $65^{\circ} \mathrm{C}\left(150^{\circ} \mathrm{F}\right)$. Phillips (1941) saw no steam emmission at the summit but did locate a vent about one foot in diameter which felt "slightly warm." "The temperature was less the $38^{\circ} \mathrm{C}\left(100^{\circ} \mathrm{F}\right)$, the lowest temperature that his thermometer would measure. This vent was reported to be about one-fourth mile north of the sumit in the center of a broad snowfield (Moxham, 1970).

Moxham (1970) reports that IR surveys were unable to identify any thermal anomalies on Mount Adams. He con. luded that either the reported steam jets have diminished to an undetectable level over the period since they were last observed, or they are too small to be detected by IR.

..Geophysical Summary: No known geophysical work has been performed in the Mount Adams area.

..Geologic Hazards: The principal geologic hazards that would be encountered in the area involve slope stability problems and the potential for landsliding or debris slides and those hazards associated with volcanic events.

Al though Mount Adams has been inactive in historic time, a variety of events that have occurred since the latest glaciation are recorded in geologic formations. New volcanic activity, which could occur without warning, could result in property damage and the possible loss of life.

Mount Adams, unlike Mount St. Helens, does not have a record of major pyroclastic eruptions, and therefore the chance of a devastating debris flow is less likely to occur on Mount Adams. Lava flows comprise at least 75 percent of Mount Adams, and Mount St. Helens is approximately. 85 percent tephra and flowage deposits (Hopkins, 1976).

The latest large mudflow from Mount Adams is the Trout Lake Mudflow, which covers approximately $16 \mathrm{~km}^{2}$ of the valley floor along the White Salmon River, near Trout Lake. The flow, which is $8 \mathrm{~km}$ long and up to $600 \mathrm{~m}$ thick, is dated at $5,070 \pm 260$ years B.P.

In addition to the above, the study area is within Rasmussen's (1976) zone of potential moderate damage from earthquake activity. 


\section{RESERVOIR CHARACTERISTICS}

. Reservoir Temperature

..Surface: Approximately $65^{\circ} \mathrm{C}\left(150^{\circ} \mathrm{F}\right)$ (Fowler, 1935).

..Subsurface: No information is available.

..Geochemical:

.. $\mathrm{SiO}_{2}$ : No information is available.

...Na-K-Ca: No information is available.

.Flow Rates: No information is available.

..pH: No information is available.

..Total Dissolved Solids: No information is available.

..Fluid Chemistry: No springs in the area have been sampled for geochemical analysis.

..Estimated Nonelectric Energy Potential (MBtuh 30 years): No estimate is possible at this time.

..Subsurface Area of Reservoir: No estimate is possible at this time. 
LAND OWNERSHIP AND LEASING

\begin{tabular}{|c|c|c|c|c|c|}
\hline . Land Ownership & $\begin{array}{l}\text { TOTAL AREA } \\
\text { (Acres) } \\
368,640\end{array}$ & $\begin{array}{l}\text { FEDERAL } \\
\text { (Acres) } \\
195,840\end{array}$ & $\begin{array}{l}\text { STATE } \\
\text { (Acres) } \\
23,040\end{array}$ & $\begin{array}{l}\text { PRIVATE } \\
\text { (Acres) } \\
11,520\end{array}$ & $\begin{array}{l}\text { OTHER } \\
\text { (Acres) } \\
138,240\end{array}$ \\
\hline . Land Leased & None & None & None & None & None \\
\hline $\begin{array}{l}\text { Highest Priced Leases } \\
\text { (Dollars/Acre) }\end{array}$ & N/A & N/A & $N / A$ & $N / A$ & $N / A$ \\
\hline
\end{tabular}

..\$/Acre Lessee

N/A N/A

. Tentative Lease Sale Dates:

No lease sale dates have been set.

. Number of Sales Offered

But No Bids:

N/A

N/A

N/A

N/A

N/A

.. Number of Bids Rejected (Resulting in No Lease): No area has been put up for leasing and no date for leasing has been set.

.. Summary of Leasing Status and Needs: Leasing within the Mount Adams Wilderness Area and the Yakima Indian Reservation is, under provisions of present law, impossible (Geothermal Steam Act, 1970) (Appendix I). Leasing, however, could take place on Indian lands through the Indian Council. Leasing of national forest lands is under the jurisdiction of BLM, but cannot take place until an environmental statement is prepared and okayed by the surface management agency, which in this case is the U.S. Forest Service. At the present time, an environmental statement is being prepared by the forest service.

No provision for the leasing of state lands has been made under Washington law.

The Yakima Indian Council has not, as of this time, expressed an interest in the leasing of tribal lands for geothermal exploration and development. 
..Present Development Status: At present there is no geothermal development in the Hount Adams PGRA.

..Projected or Planned Development: There is no planned or projected geothermal development in the area at this time. Geothermal development within the boundaries of the Mount Adams Wilderness Area is forbidden by 1 aw (Geothermal Steam Act, 1970)(Appendix I). Development on lands under the jurisdiction of the Yakima Nation will depend upon decisions by the tribal council. Development in areas under the jurisdiction of the Gifford Pinchot National Forest cannot progress until such time as an environmental statement is prepared and leasing can begin through the BLiM regional office. At present, an environmental statement to cover this area is under preparation. 


\section{INSTITUTIONAL CHARACTERISTICS}

..Institutional Requirements: The Geothermal Steam Act of 1970 (Appendix I) precludes the leasing of lands within a wilderness area or on Indian reservations.

Forest service lands cannot be leased until after the preparation of and the acceptance of an environmental statement concerning geothermal leasing by the surface management agency.

The question of the ownership of geothermal resources on state or private land, as well as the leasing of state lands, is at present under consideration.

..Agency and Public Attitudes: Environmental statements for geothermal leasing have been receiving low priority from the forest service.

The Washington Department of Natural Resources and the Washington Energy Office, as well as the Washington Interagency Geothermal Development Council, are at present very interested in developing plans for geothermal assessment and the eventual development of geothermal resource in the state.

..Status of Requirements (i.e., EIA/EIS Requirements): At the present time, there are plans under consideration concerning the preparation of an environmental statement for geothermal leasing on the federal lands concerned.

At present the State Interagency Geothermal Development Council is looking into various alternative suggestions concerning ownership of the resource and the leasing of state lands. It is hoped that it will be possible to have requirements accepted and leasing procedures developed within the next two years. 
ENVIRONMENTAL FACTORS

..Cl imate

.Prevailing Winds: Winds are from the northwest to west northwest. The strongest winds are generally from a southeasterly to southwesterly direction and associated with intense weather systems moving inland during the fall and winter (Phillips, 1964).

..Precipitation (Annua 1): Mean annual precipitation at Mount Adams Ranger Station is $1,204.4 \mathrm{~mm}$ (47.42 inches). Highest precipitation is from November to March (Phillips, 1964).

..Days of Sunshine (Annual): No information is available.

. Average Temperature: Mean annual temperature is $8.11^{\circ} \mathrm{C}\left(46.4^{\circ} \mathrm{F}\right)$ at Mount Adams Ranger Station (Phillips, 1964).

Minimum: Mean minimum temperature at Mount Adams Ranger Station is $1.03^{\circ} \mathrm{C}\left(33.85^{\circ} \mathrm{F}\right)$ (Phillips, 1964).

Maximum: Mean maximum temperature at Mount Adams Ranger Station is $15.06^{\circ} \mathrm{C}\left(59.1^{\circ} \mathrm{F}\right)$ (Phillips, 1964).

..Degree Days (Annual): Mount Adams Ranger Station has 6,820 heating degree days on a base $18.3^{\circ} \mathrm{C}\left(65^{\circ} \mathrm{F}\right)$ (Phillips, 1964).

..Relative Humidity (Seasonal Peaks: (At Yakima)

Summer: $04^{\circ} 73$ percent $16^{\circ \circ} 28$ percent

Winter: $04^{\circ 0} 84$ percent $16^{\circ 0} 71$ percent

(Phillips, 1960)

. Air Quality: Air quality is very high. Main pollutants are particulates in the form of dust or at times from forest fires and slash burning (Wheeler, 1978).

..Geologic Factors: The main geologic factors of environmental interest are slope stability problems and events which would be expected to accompany volcanic activity. Of primary concern would be debris flows as a result of the melting of large amounts of ice and snow (Wheeler, 1978; Hopkins, 1976).

. Water quality: Water quality in the area is very high. Streams in the area are rated as Class AA (extraordinary) (Washington Administrative Code [WAC] Chapter 173-201 WAC: James, personal communication, 1978).

.. Noise: Ambient noise levels are low. (Additional information has been requested from the forest service.)

..Biological

..Dominant Flora: The area contains species common to the ArcticAlpine as well as the Canadian and Hudsonian Life Zones. 
The Arctic-Alpine species include: Juniperus sibirica, Salix cascadensis, Salix nivalis, Gaultheria humifusa, Empetrum nigmu, and the heathers Phyllodoce granduliflora, Cassiope mertensiana, and Cassiope stelleriana.

The Hudsonian species are: alpine fir Abies Zasiocarpa, mountain hẹmlock Tsuga mertensiana, Alaska Cedar Chamaecyparis nootkatensis, and white-barked pine Pinus albicaulis. Common shrubs include: Salix barclayi, Salix conmutata, Juniperus sibirica, Alnus sinuata, Ribes howellii, Lutkea pectinata, Potentilla fruticosa, Sorbus occidentalis, Spiraea densiflora, Pachistima myrsinites, Arctostaphylos nevadensis, Arctostaphylos uva-ursi, Cassiope mertensiana, Cassiope stelleriana, Phyllodoce empetriformis, Rhododendron albiflomm, and Gaultheria ovalifolia.

The Canadian species include: Douglas fir Pseudotsuga taxifolia, western hemlock Tsuga heterophy Zla, amabaslis fir Abies amabalis, white pine Pinus monticola, and noble fir Abies nobilis.. Shrubs include: Vaccinnium ovalifolium, Vaccinnium membranaceum, Menziesia fermuinea, Alnus sinuata, Acer circinatum, Sorbus cascadensis, Cornus canadensis, Clintonia uniflora, Stenauthizm occidentale, Galium oreganum, and Prenanthes lessingii. Saprophytes are abundant in the Canadian Zone (U.S. Army Corps of Engineers, 1973).

..Dominant Fauna: Dominant species include: elk, black-tailed deer, mountain goat, black bear, beaver, raccoon, mink, muskrat, river otter, bobcat, cougar, snowshoe hare, chickaree, white-footed deer mouse, goshawk, bendire, red crossbili, blue grouse, white tailed ptarmigan, spruce (Franklin) grouse, and band-tailed pigeon (U.S. Army Corps of Engineers, 1973).

.. Endangered, Rare, Remnant, Unique or Otherwise Significant Species:

.Flora: Tree specimens--Evergreen: Ponderosa pine Pinus ponderosa. (U.S. Army Corps of Engineers, 1973).

.Fauna: Fowl--American peregrine falcon Falco peregrinus anatum, (endangered), blue grouse, band-tailed pigeon, eastern goshawk, white tailed ptarmigan (U.S. Army Corps of Engineers, 1973).

Mammals--fisher Martes pennanti, red fox Vulpes fulva cascadensis, wolf Canis Zupus fuscus, Canada lynx Lynx canadensis, and longeared myotis Myotis evotis pacificus. Critical elk range is also found within the area. 
..Utility or Energy Transmission Corridors and Facilities One $69 \mathrm{KV}$ line approximately $22.5 \mathrm{~km}$ (14 miles) southeast--owned by Puget Sound Power and Light. (Line is expected to increase to $110 \mathrm{KV}$. )

One $69 \mathrm{KV}$ line approximately $32 \mathrm{~km}$ (20 miles) south--owned by klickatat Co. PUD.

One $230 \mathrm{KV}$ line and $500 \mathrm{KV}$ line approximately $40 \mathrm{~km}$ (25 miles) south -owned by BPA (U.S. BPA Area Office Map, Sheet 8, 1974 and BPA Area Office Map, Sheet 9, 1974).

. Transportation Corridors or Facilities: Main transportation routes include state route 141 to Trout Lake, and forest service routes $N 84$, $N 840$ and $N 80$, all of which service the Gifford Pinchot National Forest. No roads are allowed within the boundaries of the Mount Adams Wilderness Area (Washington State Highway Commission Map, 1975; U.S. Forest Service, Gifford Pinchot National Forest Map, 1976). 


\section{POPULATION}

..General Description of Population: The population of the area is low and widely scattered. No population center is located within the study area. Al though Mount Adams is located in Yakima County, it is felt that the greatest potential use of any resource would be to the south in Klickitat and/or Skamania Counties. The total population of Klickitat and Skamania as of 1977 is 20,000 and the population density is 7.28 and 3.64 , respectively. The two counties have experienced a population increase of 12.69 percent and 4.34 percent, respectively, since 1970 .

Three population centers which could be served are--Goldendale with a population of 3,310 , White Salmon with a population of 1,715 , and Stevenson with a population of 963 (Washington Office of Financial' Management, 1977).

Employment is primarily in the timber products industry, including both timber harvesting and the manufacture of timber products.

...Economic

..Present Land Use: The primary land use in the Mount Adams Wilderness Area is recreation. Outside the wilderness area timber production is dominant and forms the economic base for the region. Timber production and related industries employ the largest number of individuals in the area.

..Future Land Use: No significant changes in land use patterns or the economic base of the area is expected. 
29

INDIAN HEAVEN KGRA 


\section{FIGURE 5- GEOTHERMAL LAND CLASSIFICATION MAP}

\section{INDIAN HEAVEN KGRA}

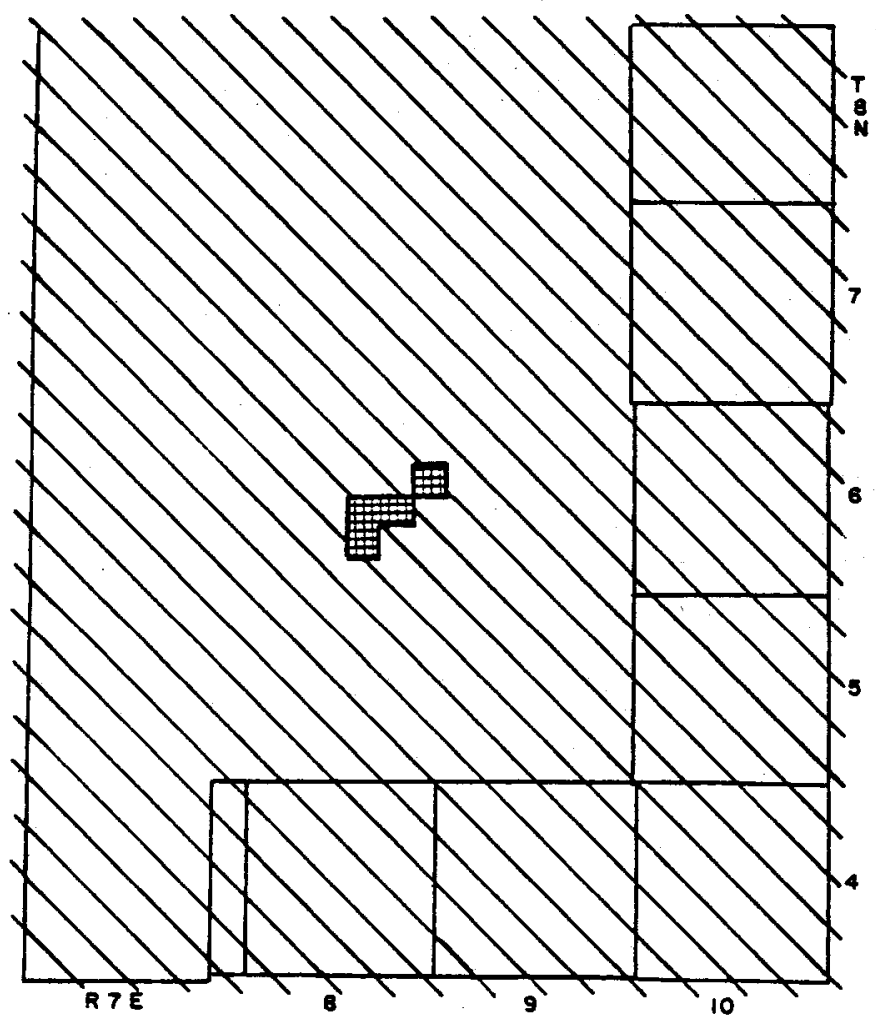

\section{LEGEND}

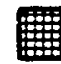

KNOWN GEOTHERMAL RESOURCES AREA

D

LANDS VALUABLE PROSPECTIVELY FOR

GEOTHERMAL RESOURCES

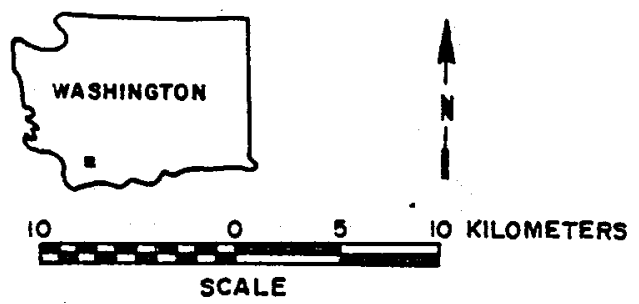

Bose map: U.S. Geological Survey Geothermal Lond Classificotion Map, Woshington, 1974 


\section{INDIAN HEAVEN KGRA}

\section{Introduction}

The Indian Heaven KGRA (Known Geothermal Resource Area) encompasses 2,547 acres in the southwestern part of the state. The KGRA is part of the Indian Heaven PGRA (Potential Geothermal Resource Area) which encompasses 483,890 acres in the Gifford Pinchot National Forest. The KGRA is ca. $32 \mathrm{~km}$ (20 miles) northwest of White Salmon, Washington, in Skamania County.

The rectilinear location of the Indian Heaven KGRA is secs. 13, 22, 23, and 27 of T. 6 W., R. 8 E.

The area has been designated as a KGRA by the U.S. Geological Survey on the basis of overlapping lease applications. The area is, however, not considered to be one of the top geothermal prospects in the state. Heat-flow drilling by the Washington Division of Geology and Earth Resources has established that the area, although containing young volcanics, does not have a heatflow above the normal for the Cascades. Geothermometry points to reservoir temperatures of ca $60^{\circ} \mathrm{C}$ for the thermal springs in the PGRA.

Present energy needs which could potentially be met by geothermal resources are extremely difficult to assess. Heat-flow drilling in the Indian Heaven area by the Washington Division of Geology and Earth Resources has done little to define the potential for low temperature resources at depth. However, the drilling did establish that no largesized heat source body exists in the KGRA. The existence of a low temperature resource at depth is suggested by geothermometry from three thermal springs which are in the Indian Heaven PGRA. No surface manifestations are known in the KGRA.

If reservoir temperatures are near those predicted by geothermometry $\left(50-60^{\circ} \mathrm{C}\right)$, then the use of the resource would be limited to irrigation and possibly space and greenhouse heating utilizing heat pumps. However, the use of the resource would most likely prove to be uneconomical due to distances to potential users. Thus additional geological and geophysical assessment work is required before the potential for utilization is more carefully considered.

No population centers are found in the KGRA. The town of Trout Lake is ca. $16 \mathrm{~km}$ (10 miles) to the east of the KGRA and Carson is ca. $26 \mathrm{~km}$ (16 miles) to the south. The population of the potential service area is less than 30 per kilometer. The dominant land uses in the potential service area are timber production and recreation. In the KGRA land use is entirely recreational as the area is roadless.

Topographically the KGRA is characterized by small volcanic cones and lakes. Elevations reach $1,636 \mathrm{~m}(5,368 \mathrm{ft}$.) at East Crater.

Several lease applications have been filed in the area, but to date no leases have been issued and the failure to issue leases has prevented further exploration by private concerns. 
The leasing of land in the KGRA by BLM can take place only after the potential environmental impacts of geothermal exploration and development are assessed by the forest service. Completion of the assessment is expected by late 1979 or early 1980 and a lease sale could take place by mid-1980.

Opposition to leasing in this area is expected from environmental groups. Previous environmental studies concerning geothermal exploration and development in the Gifford Pinchot National Forest has stressed the environmental sensitivity of the area and the forest service has recommended leasing only portions of the forest. Even then, many of the areas which were recommended for leasing have no surface occupancy requirements.

Assessment of the area will take place over the next 3 to 5 years as part of the U.S. Geological Survey-Washington Division of Geology and Earth Resources cooperative program for the assessment of the Cascade Range. The initial focus of the program is expected to be Mount St. Helens, and it is not at present clear at what point in the program that the Indian Heaven KGRA will be considered.

If adequate levels of funding are established and maintained for the preparation of environmental statements and for geological/geophysical assessments, lease sales should take place in March 1979 and assessment work should be completed by 1984-1985. 
SITE DATA SUMMARY

SITE: Indian Heaven KGRA

..Physical Reservoir Data

$\therefore$ Temperature ${ }^{\circ} \mathrm{C}$

Surface: $4.0^{\circ}-4.5^{\circ} \mathrm{C}$ (Schuster et al., 1978).

Subsurface: $15^{\circ}-40^{\circ} \mathrm{C}$ (estimated from $\mathrm{Na}-\mathrm{K}-\mathrm{Ca}$ ) (Schuster et al., 1978).

..Total Dissolved Solids (PPM): Ca. 50 ppm (Schuster et al., 1978).

..Estimated Non-Electric Energy Potential (MBtuh 30 years: No estimate is possible at present.

..Type of Overlying Rock: Quaternary basalts and interbedded cinders and ash (Schuster et al., 1978).

..Estimated Depth to Top of Reservoir (meters): No estimate is possible.

..Site Land Status

$\begin{array}{ccc} & \text { FED. STATE PRIVATE } & \text { OTHER } \\ \text { Total Acres } & 2,547 \\ \text { Total Acres Leased None } & \\ \text { (Renner and Lee, 1974; Cullins, 1977) }\end{array}$

..Geothermal Development Status: No development to date. The Washington State Department of Natural Resources has done heat flow drilling in the area. Normal heat flow values were obtained. No development at the site can begin until the U.S. Forest Service EIS is completed and the area is open to leasing by BLM. The EIS, which is in progress, cannot be expected to be finished until late 1979 (Schuster et al., 1978; Hutchins, personal communication, 1978).

..Local and State Attitude Toward Geothermal Development: Very low interest by the Washington Department of Natural Resources due to normal heat flow as measured in the area (Schuster, et al., 1978). Washington Departments of Ecology, Fish, and Game have expressed a high level of concern due to potential environmental impacts from geothermal development.

..Land Use and Population: The site is in the southern Cascade Range of Washington. The site is situated between Mount St. Helens and Mount Adams. Principal land uses are recreation and timber production (Wheeler, 1978). Population density in the area is very low. No permanent population centers are found within KGRA (Wheeler, 1978).

..Comments and Critical Issues: The site is located in the Gifford Pinchot National Forest. This is a very environmentally sensitive area due to its wildlife, recreational value, and the presence of very unstable soils (Wheeler, 1978). The study area is also partly a roadless area. (Schuster, personal communication, 1978). 
At the present time the forest service is preparing an EIS in regard to geothermal leasing. It is expected that the EIS will be complete by late 1979 at which time BLM could hold lease sales. 
.. Latitude: $46^{\circ} 0^{\prime} \mathrm{N}$.

.. Longitude: $124^{\circ} 45^{\prime} \mathrm{W}$.

. Rectilinear: Sections 21, 13, 22, 23, and 27, T. 6 N., R. 8 E. (Renner and Lee, 1974; U.S. Forest Service Gifford Pinchot National Forest Map, 1976)

..County: Skamania.

.Adjacent Counties: Clark, Cowlitz, Lewis, Yakima, and Klickitat (Washington State Highway Commission, 1975).

.. Topography: Cascade Mountains between Mount St. Helens and Mount Adams. Elevations range from $1,220 \mathrm{~m}(4,003 \mathrm{ft}$.) to $1,675 \mathrm{~m}(5,495$ ft.). Numerous glacial lakes are present in the area (Wind River quadrangle, 15-minute series, 1957).

..Present Land Use: The KGRA is an area primarily used for recreational purposes. Sheepgrazing takes place during part of the summer. Timber harvesting is common in other parts of the Gifford Pinchot National Forest (Wheeler, 1978).

..Future Land Use Plans: The KGRA is expected to remain primarily a recreational area.

..Aesthetics: The area, situated in the high Cascades between Mount St. Helens and Mount Adams, has high aesthetic value. This aesthetic value is extremely important as the area is roadless and viewed from the Cascade Crest Trail (Wheeler, 1978).

..Historical/Archaeological Significance: There are no known archaeological sites in the area, but no thorough archaeological study has been undertaken in the Gifford Pinchot National Forest (Wheeler, 1978).

Although thirty-one Cultural Resource sites have been identified in the Gifford Pinchot National Forest, none falls within the KGRA. As of this time none of the Cultural Resource Sites has been added to the list of historical places (Wheeler, 1978; Odegaard, 1976). 
.Geologic Description: The Indian Heaven KGRA lies between two of the large stratovolcanoes of the Cascade Range--Mount St. Helens and Mount Adams. The Indian Heaven basalt field, of which the KGRA is part, covers an area of ca. 2,200 $\mathrm{km}^{2}$. The Tertiary rocks are primarily a mixture of pyroxene andesites, basalts, rhyodacite, dacite, and rhyolite. The sequence consists of lava flows, breccias, lahars, and tephra deposits.

The Tertiary rocks were extensively altered by regional metamorphism, and extensively folded and faulted. Most of the faults are normal and trend north to northwest. Fold axes in the study area trend northeast.

The Quaternary basalts were extruded upon the folded and faulted Tertiary rocks from the Indian Heaven fissure zone which extends from Red Mountain some $30 \mathrm{~km}$ north to Steamboat Mountain. The basalts are all believed to be younger than 690,000 years on the basis of magnetic data, and some are dated as between 450 to 4,000 years on the basis of tephra deposits from Mount St. Helens which are interbedded with the basalts (Schuster et al., 1978).

..Geophysical Summary: Geophysical surveys which cover the KGRA include gravity, aeromagnetic, microearthquake, and heat flow.

As seen from gravity and aeromagnetic data in Schuster et al (1978), a gravity low of ca. $100 \mathrm{mgals}$ and a aeromagnetic high of ca. 1,500 gammas coincide with the Indian Heaven fissure zone. See Schuster et al (1978) for details.

Microearthquake surveys (Crosson 1972; Crosson and Millard, 1974; Unger and Mills, 1973) were centered too far from the Indian Heaven KGRA for the results to be adequate for the area, and a detailed microearthquake survey of the study area would be most desirable.

Heat-flow data was collected in 1975 by the Washington Division of Geology and Earth Resources. Seven holes were drilled and four of these reached the planned depth of 150 meters.

Gradients ranged from 44.5 to $58^{\circ} \mathrm{C} / \mathrm{km}$ and heat flows ranged from 1.3 to $1.8 \mu \mathrm{cal} / \mathrm{cm}^{2} \mathrm{secl}$. (Schuster et al., 1978).

These values are reported by Schuster et al (1978) as being typical regional heat-flow values for the Cascade Mountains and indicate that there is no large-sized heat source body within the general area of the heat-flow study.

..Geologic Hazards: Wheeler (1978) reports the existence of severe slope stability problems in this portion of the Cascade Range.

The potential hazard to the study from a volcanic eruption at Mount St. Helens or Mount Adams has not been studied in detail. However, it is felt that the greatest danger would come from ash flows resulting from a pyroclastic eruption. 


\section{RESERVOIR CHARACTERISTICS}

. .Reservoir Temperature

..Surface: $4.0^{\circ}-4.5^{\circ} \mathrm{C}$ (Schuster et al., 1978).

..Subsurface: No information is available.

..Geochemical

Si02: $50^{\circ}-65^{\circ} \mathrm{C}$ (Schuster et al., 1978).

$\mathrm{Na}-\mathrm{K}-\mathrm{Ca}: 15^{\circ}-40^{\circ} \mathrm{C}$ (Schuster et al., 1978).

..Flow Rates: ca. 0.25 1/s (Schuster et al., 1978).

..pH: $6.9-7.1$ (Schuster et al., 1978).

..Total Dissoved Solids: ca. 50 ppm (Schuster et al., 1978).

..Fluid Chemistry:

C1 $\frac{\text { Spring } 72}{1.0 \mathrm{ppm}}$

$\mathrm{Na} \quad 3.4 \mathrm{ppm}$

$\mathrm{K} \quad 0.6 \mathrm{ppm}$

Ca $\quad 1.0 \mathrm{ppm}$

$\mathrm{SiO} 219 \mathrm{ppm}$ $\frac{\text { Lonesome Sale }}{6.0 \mathrm{ppm}}$

$6.0 \mathrm{ppm}$

$0.6 \mathrm{ppm}$

$2.0 \mathrm{ppm}$

$24 \quad \mathrm{ppm}$ $\frac{\text { Spring } 710}{1.0 \mathrm{ppm}}$

$2.6 \mathrm{ppm}$

$0.3 \mathrm{ppm}$

$1.5 \mathrm{ppm}$

$15 \mathrm{ppm}$

... Estimated Nonelectric Energy Potential (MBtuh 30 years): No estimate is possible at present.

..Subsurface Area of Reservoir: No estimate is possible at present. 
.Land Ownership

TOTAL AREA

(Acres)

2,547

None

FEDERAL

(Acres)

2,547

None

...Highest Priced Leases (Dollar)

Acre)

..\$/Acre Lessee

N/A N/A

..Tentative Lease

Sale Dates:

No date for lease sales has been set.

... Number of Sales

Offered But No Bids:N/A

N/A

.. Number of Bids Rejected (Resulting in No Lease): N/A

.. Summary of Leasing Status and Needs: Leasing cannot begin in the Indian Heaven KGRA until the forest service completes an EIS for the area in regard to geothermal leasing. No definite date has been set for the completion of the EIS which is at present in the preliminary stages, but it is estimated that the environmental statement could be completed by late 1979 (Wheeler, 1978). 
..Present Development Status: No development has begun in the area. A number of heat flow wells have been drilled in the area by the Washington Department of Natural Resources (Schuster et al., 1978).

..Projected or Planned Development: There is no known planned or projected development in the area. 
... Institutional Requirements: An environmental statement (EIS) will have to be completed and okayed before BLM can hold lease sales.

..Agency and Public Attitudes: It is believed that U.S. Forest Service opposition to leasing will be strong due to very sensitive soils in the area, wildlife requirements, and aesthetics.

Environmental groups, as well as the Washington Department of Fish and Game, are expected to oppose leasing and development because of wildlife requirements in the area and because it is believed that any development will result in a lessening of the wilderness experience (Wheeler, 1978).

.. Status of Requirements (i.e., EIA/EIS Requirements): An EIS is being prepared by the forest service, but no draft of same is expected until 1979. Review of said draft could take 1 year. 


\section{ENVIRONMENTAL FACTORS}

..Climate

..Prevailing Winds: Prevailing winds are from the southeast to southwest (Phillips, 1964).

. Precipitation (Annual): Mean annual precipitation is 1,445 mm (47.42 in.) at Mount Adams Ranger Station (Phillips, 1964).

..Days of Sunshine (Annual): No information is available.

..Average Temperature

Minimum: The mean minimum temperature at Mount Adams Ranger Station is $1.06^{\circ} \mathrm{C} \cdot\left(33.9^{\circ} \mathrm{F}\right)$ (Phillips, 1964).

Maximum: The mean maximum temperature at Mount Adams Ranger Station is $15.06^{\circ} \mathrm{C}\left(59.7^{\circ} \mathrm{F}\right)$ (Phillips, 1964).

..Degree Days (Annual): The average for the potential service area is 5,692 on a base of $18.3^{\circ} \mathrm{C}\left(65^{\circ} \mathrm{F}\right)$ (Phillips, 1964).

.. Relative Humidity (Seasonal Peaks)

Summer: $4^{\circ} \quad 80$ percent $16^{\circ} 46$ percent

Winter: $\quad 4^{\circ \circ} 86$ percent $16^{\circ 0} 76$ percent

(Phillips, 1964)

..Air Quality: The main pollutants are dust and smoke. Air quality is high to very high except during periods of slash burning or in time of forest fires.

.Geologic Factors: Some areas have slope stability problems (Wheeler, 1978).

.. Water Quality: The water quality is very high. Streams in the area are rated as Class AA (extraordinary). All streams are in the Gifford Pinchot National Forest, and all are under federal ownership. The streams in the area surrounding the KGRA would have a combined flow of at least 141,000 to 198,000 1/s (Washington Administrative Code [WAC] Chapter 173-201 WAC; Landes, 1917; James, personal communication, 1978).

.. Noise: Information concerning noise levels has been requested from the forest service. Ambient noise levels are low.

..Biological

. Dominant Flora: The study area is dominated by species of the Canadian and Hudsonian Life Zones.

The dominant evergreen species include: Douglas fir Pseudotsuga taxifolia, western hemlock Tsuga heterophylza, western red cedar Thuja plicata, amabaslis fir Abies amabilis, ponderosa pine Pinus 
ponderoas, lodgepole pine Pinus contorta, and grand fir Abies grandis. Cottonwood Populus hastata, and broadleaf maple Acer macrophyzzum are common along stream bottoms. The ground vegetation includes: huckleberry Vaccinium parvifolium, Vaccinium ovatum, vine maple Acer circinatum, salal Gaultheria shazlon, Oregon grape Berberis nervosa, snowbush symphoricarpos albus, and salmonberry Rubus spectablis. Common forbes include sword fern Polystichum munitum and bracken fern Pteridium aguilinum (Wheeler, 1978; U.S. Army Corps of Engineers, 1973).

.Dominant Fauna: Dominant species include: elk, black-tailed deer, black bear, beaver, raccoon, mink, muskrat, bobcat, cougar, snowshoe hare, blue grouse, and ruffled grouse (Wheeler, 1978; U.S. Army Corps of Engineers, 1973).

..Endangered, Rare, Remnant, Unique or Otherwise Significant Species:

.Flora: Virgin stands--Steamboat Mountain Natural Area. Tree specimens--ponderosa pine Pinus ponderosa (K1ine, 1977; U.S. Army Corps of Engineers, 1973).

..Fauna: fisher Martes pennanti, red fox Vulpes fulva cascadensis, wolf Canis lupus fuscus, wolverine Gulo luscus luteus, Canada lynx Lynx canadensis, and long-eared myot is Myotis evotis pacificus (KI ine, 1977; U.S. Army Corps of Engineers, 1973). The area is also critical as elk range (Wheeler, 1978). 
..Utility or Energy Transmission Corridors and Facilities:

One $69 \mathrm{kV}$ line ca. $53 \mathrm{~km}$ ( 33 miles) west--owned by Pacific Power and Light Co. The line is expected to be increased to $110 \mathrm{KV}$.

One $240 \mathrm{kV}$ i ine ca. $19.3 \mathrm{~km}$ (12 miles) east--owned by Pacific Power and Light Co.

(BPA Area Office Map, Sheets 8 and 9, 1974)

. Transportation Corridors or Facilities:

State routes 504 and 141 are within $40 \mathrm{~km}$ (25 miles) and $12 \mathrm{~km}(7.5$ miles) respectively of the KGRA.

Forest service all weather road $\mathrm{N} 605$ extends to within $1.5 \mathrm{~km}(0.9$ miles) of the KGRA (U.S. Forest Service Gifford Pinchot National Forest Map, 1976). 
..General Description of Population: The population of the potential service area is low and widely scattered. No population center is located in the KGRA and distances to population centers and industrial sites is considerable. Klickitat and Skamania counties would likely form the service area and together have a 1977 population of 20,000.

Employment is primarily in the timber products industry including both timber harvesting and the manufacturing of timber products (Washington Office of Financial Management, 1977).

.. Economics

..Present Land Use: The primary land use in the Indian Heaven KGRA is recreation. Outside the area timber production is dominant and forms the economic base of the region. The timber products industry employs the largest number of individuals in the potential service area (Wheeler, 1978).

..Future Land Use: No significant changes in land use patterns is expected. 
45

MOUNT ST. HELENS KGRA 
FIGURE 6- GEOTHERMAL LAND CLASSIFICATION MAP

MOUNT ST. HELENS KGRA

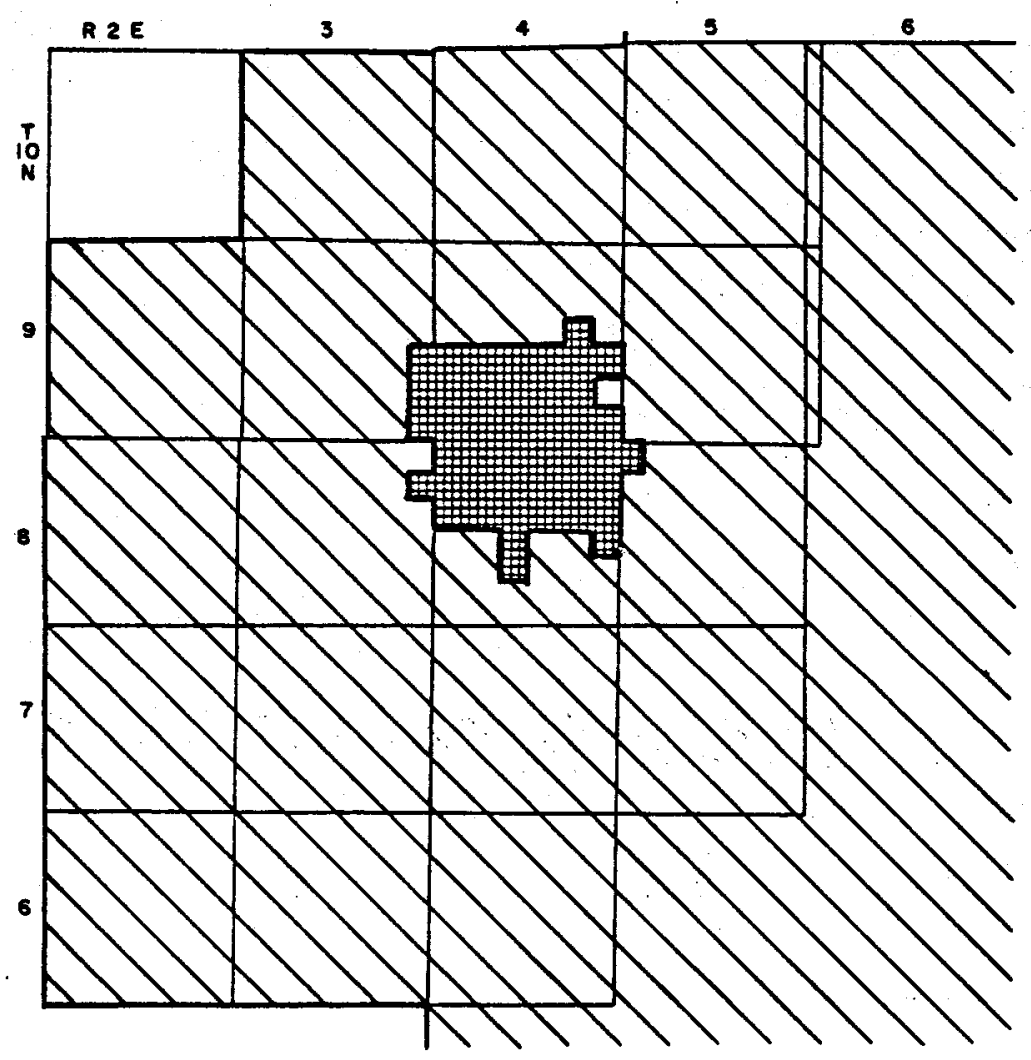

\section{LEGEND}

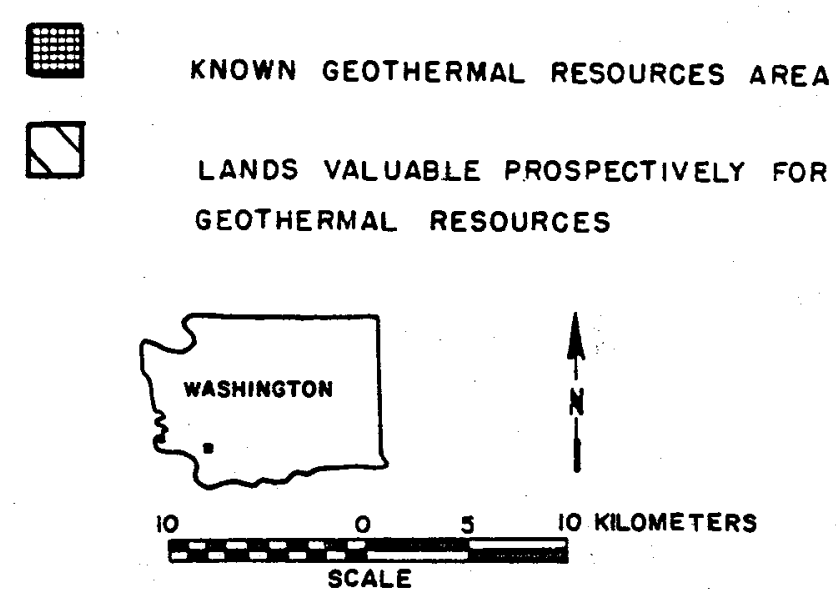

Bose map: U.S. Geological Survey Geothermal Land Clossification Map, Woshington, 1974 
MOUNT ST. HELENS KGRA

Introduction

The Mount St. Helens KGRA (Known Geothermal Resource Area) includes 29,754 acres in the southwestern part of the state, in Skamania County. The study area includes most of Mount St. Helens, which is the youngest and historically most active of the major stratovolcanoes in Washington. The KGRA includes 27,834 acres in the Gifford Pinchot National Forest and 1,920 acres of privately owned land.

The rectilinear location of the peak of Mount St. Helens is sec. 9, T. 8 N., R. 5 E.

The area was classified as a KGRA by the U.S. Geological Survey. The area is considered to be one of the top prospects in the state if not the prime prospect.

Mount St. Helens in the probable focus of the U.S. Geological Survey Washington Division of Geology and Earth Resources joint Cascade Range Geothermal Assessment program for f.y. 1979. The study area has received a great deal of attention by private concerns and lease applications have been filed with BLM on most of the federal acreage outside the KGRA. (Acres within the KGRA are leased by competitive bid.) Mount St. Helens has also been the subject of numerous geological and geophysical studies, including gravity, IR, and microearthquake.

Although Mount St. Helens has been historically the most active of the stratovolcanoes in Washington, no thermal springs are present in the KGRA. Surface manifestations are absent except for the Boot area where fumeroles have been observed covering an area of ca. $15 \mathrm{~m}(50 \mathrm{ft}$.) by 45 $\mathrm{m}(150 \mathrm{ft}$.$) by direct observation and IR$

Land use in the KGRA includes recreation and timber production. Outside the KGRA, timber production, recreation, and agriculture dominate land use patterns and are a reflection of the topography of the region. Recreation and timber production predominates at lower elevations to the west and south.

There are no permanent population centers in the KGRA and the closest town is Cougar, ca. $16 \mathrm{~km}$ ( $10 \mathrm{miles}$ ) to the southwest. Longview and Kelso are ca. $65 \mathrm{~km}$ (40 miles) to the west and Vancouver is ca. $70 \mathrm{~km}$ (43 miles) to the southwest. The potential service area could conceivably include all of Cowlitz and Clark Counties, with a combined 1977 population of 237,200 . The major population and industrial centers of the potential service area include: Vancouver (population 46,500), Longview (population 29,830), Kelso (population 10,600) and Camas (population 6,010).

Energy consumption in the potential service area is high, and present energy needs are met primarily by 0il, natural gas, and electricity. Five of the top 20 energy consumers in Washington are located in Clark and Cowlitz Counties. These major energy consumers include: Crown Zellerbach, Camas; Alcoa, Vancouver; Reynolds Metals Co., Longview; 
Boise Cascade, Vancouver; and Longview Fibre Co, Longview. The total energy demand of these five companies is $80,125\left(10^{9} \mathrm{BTU} / \mathrm{yr}\right.$.) and comprises 43 percent of the energy consumed by the 20 top energy consumers in Washington.

Present energy needs of the area that could be met by geothermal resources are impossible to predict on the basis of the limited geochemical, geological, and geophysical data presently available for the Mount St. Helens KGRA. The area is, however, considered to have the potential of supplying low temperature hydrothermal fluids. If these fluids are present in sufficient quantities and are of usable quality, then energy needs in the areas of spaceheating, greenhouses, aquaculture, timber product drying, and the preheating of industrial waters could be partially satisfied from this source.

The economical and efficient use of geothermal waters for spaceheating, greenhouses, and aquaculture has been demonstrated in several areas. Among the prinicipal users of geothermal resources are Klamath Falls, Oregon; Boise, Idaho; and Reykjavik, Iceland. Utilization of geothermal resource in the paper and timber products industry has been successfully demonstrated in Wa irakei, New Zealand.

The Mount St. Helens area has received more attention by potential developers, the state, and the federal government than any of the other KGRA's or PGRA's in the state.

The area was designated as a KGRA by the U.S. Geological Survey in 1974 and immediately attracted potential developers to the area. Lease applications were filed with BLM on all of the available forest service land surrounding the KGRA. (Acreage in the KGRA must be leased on a competitive bid basis.)

Since the initial surge of interest, leasing, explorations, and development have been delayed by the failure of the forest service to complete the required environmental assessment work. No lease sales can be held by BLM until the completion and acceptance of an environmental statement by the surface management agency that assesses the potential impacts to the area from geothermal exploration and development. The forest service, as the surface management agency, is at present completing an environmental statement. Release of the draft, with its recommendation for the issuing of leases, for public review should take place in early 1977.

Opposition to leasing in the KGRA is expected from environmental groups who are presently engaged in an attempt to obtain wilderness status for portions of the Mount St. Helens area.

Review and final acceptance of the environmental statement could be completed by 1980. At that time, lease sales can be held and leases issued. That would allow for the start of geological and geophysical exploration by private companies by late 1980 or 1981 .

Assessment work by the U.S. Geological Survey, in cooperation with the Washington Division of Geology and Earth Resources, will beg in in f.y. 1979 as part of the planned Cascade Range Geothermal Assessment Program. The program, which is designed to cover 3 to 5 years, is expected to focus initially on Mount St. Helens. 
If present program schedules are adhered to, environmental and geological/ geophysical assessment work should be competed by 1983 to 1985 . Thus the decision to commit to development could be made by the mid-1980's. 
SITE DATA SUMMARY

SITE: Mount St. Helens

- Physical Reservoir Data

. . Temperature ${ }^{\circ} \mathrm{C}$

Surface: $87.7^{\circ} \mathrm{C}\left(190^{\circ} \mathrm{F}\right)$ (Renner and Lee, 1974)

Subsurface: No information is available

. Total Dissoved Solids (PPM): No chemical data is available.

..Estimated Non-Electric Energy Potential (MBtuh 30 years): 45 MBtuh (first stage)

.. Type of Overlying Rock: Tertiary and recent volcanics consisting of andesite and basalt flows interbedded with pyroclastic materials. (Huntting et al, 1961)

..Estimated Depth to Top of Reservoir (meters): No estimate is possible.

. Site Land Status

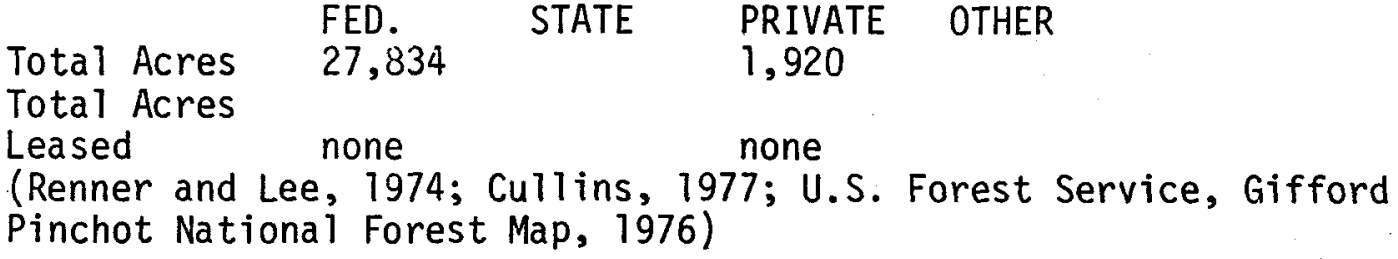

..Geothermal Development Status: No development to date. Private corporations are conducting active evaluation programs which include geochemical analysis of thermal springs and remote sensing.

..Local and State Attitude Toward Geothermal Development: There is a high degree of interest in the area by both the Washington Department of Natural Resources and the Washington Energy Office. The Washington Departments of Ecology, Fish, and Game have expressed a high level of concern for potential environmental impacts of geothermal development (Wheeler, 1978).

..Land Use and Population: The KGRA is in the high Cascades of southern Washington. Land use is restricted to timber production and recreational uses. Population density in the surrounding areas is low to very low, and there are no permanent population centers within the KGRA (Wheeler, 1978).

..Comments and Critical Issues: The completion of an EIS on the Mount St. Helens area by the United States Forest Service is of primary concern. Leasing in the area by BLM can not begin until said EIS is completed and accepted. 
Environmental concerns are high due to recreational opportunities in the area and because of the aesthetic impact any development would have.

Also of primary concern is the possibility of renewed volcanic activity on Mount St. Helens. A study, now underway, by the USGS, should upon completion shed new light upon dangers which might arise from renewed volcanism and associated mudflows.

Since a portion of the KGRA is under private ownership, full development will be impossible until the State of Washington passes laws concerning ownership of the resource and adopts legislation concerning the leasing of state lands for geothermal exploration and development. 
... Latitude: $46^{\circ} 15^{\prime} \mathrm{N}$

...ongitude: $122^{\circ} 10^{\prime} \mathrm{W}$

..Rectilinear: Sec. 9, T. 8 N., R. 5 E.

(Renner and Lee, 1974; Mount St. Helens quadrangle, 15-minute series, 1961)

..County: Skamania

..Adjacent Counties: Clark, Cowlitz, Lewis, Yakima, and Klickitat (Washington State Highway Commission, 1975).

..Topography: The study area is in the high Cascades, with elevations from 1,219 meters $(3,999 \mathrm{ft}$.$) to 2,949 meters (9,675 \mathrm{ft}$.$) . Much of the$ area is covered by steep ridges and deep canyons. Numerous glaciers are found on the mountain (Mount St. Helens quadrangle, 15-minute series, 1961).

..Present Land Use: At lower elevations forests and woodlands are present with timber production and recreation being the primary land uses. At elevations above 1,500 meters $(4,921 \mathrm{ft}$.), forests no longer exist and the primary use is recreation. Mountain climbing, hiking, and cross country skiing are popular at these higher elevations.

.Future Land Use Plans: The area is expected to retain its high recreational use due to the presence of Mount St. Helens and Spirit Lake. Timber production is expected to remain the primary economic activity (Wheeler, 1978).

..Aesthetics: This is an area of extremely high aesthetic value. The aesthetic and wilderness experience is of paramount value to visitors to the Mount St. Helens area. The presence of Mount St. Helens and Spirit Lake make for a remarkably beautiful landscape (Gifford Pinchot National Forest Map, 1976).

..Historical/Archaeological Significance: There are no known archaeological sites in the area, but no thorough archeological study has been undertaken (Wheeler, 1978).

Thirty-one Cultural Resource Sites have been identified in the Gifford Pinchot National Forest, but it has not been possible at this point to determine if any of these are located within the KGRA. As of this time none of the 31 sites has been added to the historical register, but some are being considered (Wheeler, 1978; Odegaard, 1976). 
..Geologic Description: Mount St. Helens, with a total height of $2,931 \mathrm{~m}$. $(9,671 \mathrm{ft}$.$) sits upon a platform of sandstone and mudstones that strike$ northeast and dip to the southeast. These sediments of Eocene or 0ligocene age were deformed as was the overlying Keechelus andesites before the entire sequence was intruded by granodiorite in the later Tertiary (Verhoogen, 1937; Braile, 1970; and Hyde, 1973).

The oldest dated products of volcanism at Mount St. Helens are a tephra layer 37,600 years old, and a layer containing wood with a radiocarbon age of 36,000 years (Hyde, 1973).

The cone itself consists of a wide variety of rock types in complex relationships in both time and space. The flows, which constitute only a small portion of Mount St. Helens (probably less than 15 percent of the cone), are mostly olivine basalts to pyroxene andesites. The basalts usually occur in both massive and blocky flows, and are very similar to other Cascade andesites (Braile, 1970).

Pyroclastic layers are found between the flows and vary from volcanic breccias, consisting of angular blocks as large as $1 \mathrm{~m}$ across in a sandy matrix, to white pumiceous tuffs of very low density (Braile, 1970). Repeated explosive volcanism has caused pyroclastic flows and lahars to sweep far down valleys in the vicinity of the volcano and to form thick fills of volcanic debris (Hyde, 1973).

Hopson (1971) has divided the eruptive history of Mount St. Helens into three stages:

1. Early cone building phase: growth of two dacitic domes; eruption of andesitic lava flows and nuees ardentes, culminating approximately 500 years ago in flows of olivine basalt.

2. Summit dome phase: vulcanian eruption with airfall pumice from summit ca. 450 years ago; growth of large dacitic summit dome accompanied by avalanches ca. 450-400 years ago; and subsequent flank eruptions of andesite as lava flows with precursory nuees ardentes.

3. Historic phase (1802-1857): vulcanian eruption with airfall pumice from vent on northwest flank; growth of dacitic dome from this vent; and flank eruptions of andesite from northwest and south sides of cone.

Hopson (1971) suggests that two and possibly three eruptive cycles are evident. The cycles progress from strong pyroclastic eruptions to viscous protrusions and glowing avalanches to blocky lava flows, and from hornblende-pyroxene dacite to olivine-pyroxene andesite. Andesite is believed to be the parent magma, with dacite and basalt being derivatives. The differentiation is believed to take place at shallow depth, perhaps even within the conduit. 
A total of 24 eruptions have been identified since 2,500 B.C., of these there are 13 known and dated eruptions since 1,978 B.P. (Crandel1, et al. 1975).

Folsom (1970) has dated probable volcanic events from 1800 to 1975 as occurring in 1802+, 1831, 1835, 1842, 1844, 1845, 1847, and 1854.

..Geophysical Summary: During 1970 a seismic monitoring net was established on Mount St. Helens and continuous recording took place over a 28-day period. Results showed that the frequency of local earthquakes was from 3 to 13 per day, similiar to the activity previously observed at Mount Rainier.

Epicenters form roughly linear patterns trending northeast from the summit area. Although recent geologic investigations have not revealed faults or other major geological discontinuities along this trend, the pattern of epicenters seems to be approximately aligned with the remnants of five ancestral St. Helens plug domes that trend southwest from the summit region (Unger and Mills, 1973).

In 1969 and 1970 a gravity survey of Mount St. Helens was made by Braile (1970). A series of stations was established along a northeast-southwest profile over the summit of the mountain. A Warden gravimeter 358 was employed throughout the survey.

Data obtained show a marked negative gravity anomaly is superimposed on the gravity line, which generally follows the crest of the Cascade Range. The position of Hount St. Helens, $48.3 \mathrm{~km}$ (30 miles) to the west of the Cascade crest, is at the western margin of the Cascade Tertiary volcanic rocks. The north-south trending negative Bouguer anomaly, which corresponds to the Cascade Mountains, is offset at several places. These offsets are interpreted as east-west strike-slip or transform faults that intersect and offset the Cascade Mountains. Mount St. Helens, Mount Adams, Mount Rainier, and Glacier Peak occur at or near these offsets. These lines of offset are also the locations of zones of earthquake epicenters. It appears that these offsets may determine the position of the Cascade stratovolcanoes.

Braile (1970) concludes that the existence of a sharp Bouguer residual gravity anomaly can only in part be explained by the existence of an acidic batholith, magma chamber, or older low-density sedimentary rocks beneath the mountain. The proposed mechanism which Braile feels best explains the observed gravity low is that of a volcanic process that results in the placement of low-density volcanic material beneath the mountain. This could be accomplished by the filling of the central pipe of the volcano with vesicular and brecciated material or by the collapse of ancestral Mount St. Helens into a caldera.

.. Infrared Summary: An aerial IR survey was made of Mount St. Helens in September of 1966, using a conventional line scanner aboard a D-18 Beechcraft operated by the U.S. Geological Survey. Two areas of steam vents had been reported by Lawrence (1939) near the summit: one on the southwest side of the peak, a short distance below the summit; the other about halfway up the Boot, and at its western edge. A climbing party searched for both areas in 1941 (Phillips, 1941) but found no thermal activity southwest of the peak, although they found evidence of hydrothermal alteration. They did, however, find fumaroles at the Boot that corresponded 
exactly to the earlier description. Phillips (1941) stated that "steam issues gently from crevices in the bedrock, and other areas of rock are distinctly warm even where there is no apparent discharge.... The largest fumarole has an opening not over 3 inches in diameter." The outcrop in which the steaming crevices were found is "perhaps 50 feet wide and 150 feet long, the greater dimension running down the slope of the mountain." The vents, 5 to $8 \mathrm{~cm}$ in diameter, ranged from $81^{\circ} \mathrm{C}$ to $88^{\circ} \mathrm{C}$ (Moxham, 1970).

The IR Survey results conform well with those reported by Phillips. No thermal anomaly was detected southwest of the summit, but the fumaroles at the Boot were clearly shown.

..Geologic Hazards: Geologic hazards, which could result in losses of property and life in the Mount St. Helens study area, are principally volcanic in nature, although landslides and avalanches must also be considered.

Potential volcanic hazards at Mount St. Helens are associated with nuees ardentes, mudflows, lava flows, and falls of pyroclastic debris.

Nuees ardentes seem to present the greatest hazard within a $16 \mathrm{~km}$ radius of the volcano. Nuees ardentes can travel at speeds of ca. $160 \mathrm{~km}$ per hour and have temperatures of several hundreds of degrees Celsius. Nuees ardentes present danger from both the incandescent rock debris carried in the basic flow and the accompanying cloud of hot gasses and dust. This cloud can cause asphyxiation, as well as burning the lungs and skin. In addition, forest fires can be started by the hot rock debris, and floods and mudflows may result from the melting of ice and snow by a nuees ardentes. If a nuees ardentes were to move down a valley, the most severely affected areas would be the valley floor and the valley sides to a height of several hundred feet.

Over the past 300 to 600 years volcanic eruptions have caused four large but dry avalanches of pumice and rock debris to travel down the southwest flank of Mount St. Helens and to move into the Kalama River valley. The avalanches traveled at least $10 \mathrm{~km}$ from their source and temporarily filled the valley to a minimum depth of $60 \mathrm{~m}$ (ca. $200 \mathrm{ft}$.$) .$

Mudflows from volcanoes can be caused directly or indirectly by volcanic eruptions. Some mudflows may start as large landslides, which could be triggered by earthquakes or volcanic explosions; others may be created by the spillover of a crater lake or by an eruption of hot volcanic lava or debris into snow or ice fields, which could cause large floods and the removal of loose debris on the flanks of the volcano. Mudflows may also originate as glacial outburst floods or during periods of exceptionally heavy rainfall such as those which often accompany pyroclastic eruptions.

Mudflows have been observed to flow at speeds as high as $90 \mathrm{~km}$ per hour, and they have been known to carry boulders several meters in diameter. Structures such as bridges, buildings, and dams are sometimes swept away by the mud as it moves down valley. Mudflows may temporarily pond at narrow places in the valley. Where flowage is restricted, they may overtop stream banks and spread across relatively flat areas. 
Repeated mudflows, which originated on Mount St. Helens about 2,000 years ago, moved down the Kalama River valley for distances of at least $50 \mathrm{~km}$, and some may have reached the Columbia River. The sequence of unconsolidated mudflows may be seen in the banks of the Kalama River. Some of these flows have thicknesses of up to $60 \mathrm{~m}$. Many mudflows which have originated over the past 450 years have flowed down the south side of the volcano.

Lava flows make up only a small percentage of the material that has erupted from Mount St. Helens. Of these flows, only the most fluid have reached a distance as great as 5 to $6 \mathrm{~km}$ from the summit. Several flows, which apparently erupted during a single eruptive period at 1,900 years B.P., reached a maximum length of 13 to $14 \mathrm{~km}$.

Mount St. Helens has erupted pyroclastic material many times, but the majority of these eruptions have been relatively minor and the resulting deposits are generally thin. However, thick pyroclastic deposits are known to have been formed by eruptions about 12,000,3,200, and 450 years ago. Distribution of the 12,000-year-old deposits has not been fully determined, but it seems to be extensive and is present mainly to the east and southeast of the cone. The eruption, which occurred ca. 450 years B.P., produced a layer about 3 meters thick near Spirit Lake.

Small-scale pyroclastic eruptions would not threaten life except very close to the volcano; even in the case of a large eruption, the thickest and coarsest portion of pyroclastic debris generally falls within a few $\mathrm{km}$ of the source. The distribution of the debris is determined mainiy by the strength and direction of the winds and the height of the eruptive column.

Toxic gases may accompany a pyroclastic eruption, visibility may be reduced, and burns and fires could result from falls of hot rock debris. These effects would become less serious with increasing distance from the vent. Streams, lakes, and reservoirs in the vicinity of the volcano would experience a temporary increase in acidity and turbidity and water supplies could be contaminated.

It must also be kept in mind that nuees ardentes or mudflows may result as a result of an eruption of pyroclastic material (Hyde and Crandell, 1975). 


\section{RESERVOIR CHARACTERISTICS}

. Reservoir Temperature

..Surface: $87.7^{\circ} \mathrm{C}\left(189.9^{\circ} \mathrm{F}\right)$ (Renner and Lee, 1974).

..Subsurface: No information is available.

..Geochemical

Si02: No information is available.

$\mathrm{Na}-\mathrm{K}-\mathrm{Ca}$ : No information is available..

..Flow Rates: No data is available.

..pH: No data is available.

..Total Dissolved Solids: No data is available.

.Fluid Chemistry: No springs in the area have been sampled for geochemical analysis.

..Estimated Nonelectric Energy Potential (MBtuh 30 years): It is estimated that a minimum of $45 \mathrm{MBtuh}$ can be supplied. A thorough assessment of the nonelectric energy potential is, however, impossible because of the lack of geological and geophysical data upon which to base such an estimate.

..Subsurface Area of Reservoir: No estimate is possible at this time. 
LAND OWNERSHIP AND LEASING

.. Land Ownership

..Land Leased

..Highest Priced Leases

(Dollars/Acre)

$\begin{array}{ll}\text {. \$/Acre } & \text { Lessee } \\ \text { N/A } & \text { N/A }\end{array}$
TOTAL AREA

(Acres)

29,754

None

$$
\begin{aligned}
& \text { FEDERAL } \\
& \text { (Acres) } \\
& 27,834
\end{aligned}
$$

STATE

(Acres)

None
PRIVATE OTHER

(Acres) (Acres)

None

. Tentative Lease Sale Dates:

No lease sale date has been set.

. Number of Sales Offered But No Bids:

N/A

N/A

N/A

(Renner and Lee, 1974; Cullins, 1977; U.S. Forest Service, Gifford Pinchot National Forest Map, 1976).

.. Number of Bids Rejected (Resulting in No Lease): N/A

..Summary of Leasing Status and Needs: Leasing cannot begin until the forest service completes an EIS on geothermal leasing and development. The environmental assessment is being done as part of the forest management plan for the area and is expected to be released for public review and comment during 1979. Final decisions on leasing are not expected until late 1979 or early 1980 (Hutchens, personal communication, 1978). 
59

GEOTHERMAL DEVELOPMENT STATUS

..Present Development Status: No development has begun in the area. Private corporations have been involved in remote sensing forms of exploration as well as the sampling of thermal springs (Vice, personal communication, 1978).

..Projected or Planned Development: There is no known projected or planned development in the area.

At the present time the U.S. Geological Survey in cooperation with the State of Washington Division of Geology and Earth Resources is developing plans for the geothermal assessment of the Cascade Range. Mount St. Helen has been selected as the first site of focus in Washington and work will begin by early 1979 (Schuster, personal communication, 1978). 


\section{INSTITUTIONAL CHARACTERISTICS}

.. Institutional Requirements: Federal lands cannot be leased until after the preparation of and the acceptance of an environmental statement concerning geothermal leasing by the surface management agency which in this case is the forest service.

The question of ownership and leasing of geothermal resources on state and private lands is at present under consideration.

.Agency and Public Attitudes: It is believed that forest service opposition to leasing and development will be strong due to the recreational and aesthetic values of the site.

Environmental groups as well as the Washington Department of Ecology and Departments of Fish and Game are expected to oppose development in the area due to the above stated concerns and due to wildlife values.

The Washington Department of Natural Resources and the Washington Energy Office as well as the Washington Interagency Geothermal Development Council are at present very interested in developing plans for geothermal assessment and the eventual development of geothermal resources in the state.

..Status of Requirements(i.e., EIA/EIS Requirements): An EIS on geothermal leasing and development is being prepared by the forest service as part of its forest plan for the Mount St. Helens area. The completion of this report is expected in 1979.

The Department of Natural Resources, the Washington Energy Office, and the Washington Interagency Geothermal Development Council are looking into the needs for legislation concerning geothermal leasing and development in Washington on state and private lands. 
ENV IRONMENTAL FACTORS

..Climate

..Prevailing Winds: Winds are from the northwest to west northwest. The strongest winds are generally from the southeast to south and are generally associated with intense weather systems in the fall and winter (Phillips, 1964).

.Precipitation (Annual): Mean annual precipitation is 2,373. mm (93.44 inches) (Phi11ips, 1964).

..Days of Sunshine (Annual): No information is available.

-Average Temperature: Mean annual temperature is $10.0^{\circ} \mathrm{C}\left(50.0^{\circ} \mathrm{F}\right)$ at Kosmos (Phillips, 1964).

Minimum: Mean minimum temperature at Kosmos is $3.9^{\circ} \mathrm{C}\left(39.1^{\circ} \mathrm{F}\right)$ (Phillips, 1964).

Maximum: Mean maximum temperature at Kosmos is $16.1^{\circ} \mathrm{C}\left(61.0^{\circ} \mathrm{F}\right)$ (Phillips, 1964).

..Degree days (Annual): The mean for the potential service area is 5,833 based on $18 \cdot 3^{\circ} \mathrm{C}\left(65^{\circ} \mathrm{F}\right)$ (Phillips, 1964).

- Relative Humidity (Seasonal Peaks)

Summer: $4^{\circ 0} 84$ percent $\quad 16^{\circ 0} 46$ percent

Winter $4^{\circ 0} 86$ percent $16^{\circ 0} 76$ percent

(Phillips, 1964).

..Air Quality: Detailed information has been requested from the forest service in Seattle and Vancouver. The main pollutants are dust and smoke. Air quality is high to very high except during periods of slash burning or in time of forest fire (Wheeler, 1978).

. Geologic Factors: The main geologic factors of environmental interest are slope stability problems and events which would be expected to accompany volcanic activity (Hyde and Crandell, 1975).

.Water Quality: The water quality is very high. Streams in the area are rated as Class AA (extraordinary). All streams are in the Gifford Pinchot National Forest, and all are under federal ownership. The streams in the area have a mean annual flow of approximately 113,000 1/s. Minimum flows should be $56,000 \mathrm{l} / \mathrm{s}$ (Washington Administrative Code [WAC] Chapter 173-701 WAC) (Landes, 1917; James, personal communication, 1978).

. Noise: Information has been requested from the forest service in Seattle and Vancouver. Ambient noise levels are low. 
..Dominant Flora: The area contains species common to the Humid Transition, the Canadian and Hudsonian, and the Arctic Life Zones.

The Humid Transition species include: western hemlock Tsuga heterophyzla, Douglas fir Pseudotsuga taxifolia, and red cedar Thuja plicata. Locally the western yew Taxus brevifolia, lodgepole pine Pinus contorta, and spruce Picea sitchensis are common. Deciduous trees are numerous and include: willows $S_{a l i x} s p$. , aspen Populus tremuloides, hazel Corylus californica, alder Alnus oregona, oak Quercus garryana, broadleaf maple Acer macrophyllzm, vine maple Acer circinatum, and flowering dogwood Cornus nuttallii. Sword fern Polystichum munitum and bracken fern Pteridium aguilinum are widespread. Typical shrubs include: huckleberry Vaccinium parvifolizm, Vaccinizm ovatum, Oregon grape Berberis nervosa, salal Gaultheria shazlon, and rose Rosa zymocarpa.

At higher elevations the Canadian and Hudsonian species predominate and include Douglas fir Pseudotsuga taxifolia, western hemlock Tsuga heterophylla, amabaslis fir Abies amabalis, white pine Pinus monticola, alpine fir Abies Zasiocarpa, mountain hem1ock Tsuga mertensiana, Alaska cedar Chamaecyparis nootkatensis, and white barked pine Pinus albicaulis. Saphrophytes are common as are many shrubs.

At the higher elevations in the area Arctic species predominate and include: Juniperus sibirica, Salix cascadensis, Salix nivalis, Gaultheria humifusa, Empetrum nigrum and the heathers, Phyllodoce glanduliflora, Cassiope mertensiana, and Cassiope stelleriana (U.S. Army Corps of Engineers, 1973).

..Dominant Fauna: Species included are elk, black-tailed deer, mountain goat, black bear, beaver, raccoon, mink, muskrat, river otter, bobcat, cougar, snowshoe hare, chickadee, white-footed deer mouse, blue grouse, pika, and marmots (U.S. Army Corps of Engineers, 1973). ... Endangered, Rare, Remnant, Unique or Otherwise Significant Species:

Flora: Virgin stands: "Blue Lake" and Cedar Flats Research Natural Area (Kline, 1977; U.S. Army Corps of Engineers, 1973).

Fauna: Long-eared bat corynorhinus rafinesquii townsendii, red fox Vulpes fulva cascadensis, wolf Canis lupus fuscus, wolverine GuZo Zuscus luteus, Canada lynx Lynx canadensis, and longeared myotis Myotis evotis pacificus, Cougar Felis concolor, and mountain goat Oreamis comericanus (Wheeler, 1978).

The area may also be critical as elk range (Wheeler, 1978). 
..Utility or Energy Transmission Corridors and Facilities:

One $230 \mathrm{KV}$ line approximately $9 \mathrm{~km}$ ( 5.6 miles) north--owned by Pacific Power and Light Co.

(BPA Area Office Map, Sheet 8, 1974)

..Transportation Corridors of Facilities:

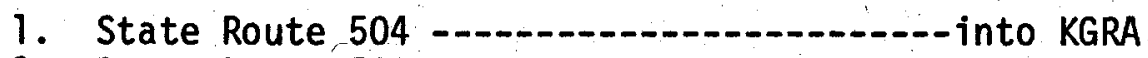

2. State Route $503-13.7$ miles) south

3. Forest Service all weather road N859-----into KGRA

4. Forest Service all weather road 100------into KGRA

5. Forest Service all weather road N83-...--into KGRA.

6. Forest Service all weather road N75-...---into KGRA

(U.S. Forest Service, Gifford Pinchot National Forest Map, 1976) 
..General Description of Population: The population of the study area is low and widely scattered. No population center is located within $16 \mathrm{~km}$ (10 miles) of the KGRA. Major population centers, which are found at a considerable distance from the site, but within the potential service area, include Castle Rock, Kelso, Longview, Vancouver, and Camas, to name just a few. The potential service area could include all of Cowlitz and $\mathrm{Cl}$ ark counties, with a combined population of 237,200 as of 1977 (Washington Office of Financial Management, 1977).

The area is highly dependent upon the forest industry and manufacturing. Both counties also have a yearly net energy deficit (Drysdale and Calef, 1977).

Economics,

..Present Land Use: Present land use in the study area is primarily timber production and recreation.

..Future Land Use: No significant changes in land use patterns of the area is expected. 
MOUNT RAINER PGRA 


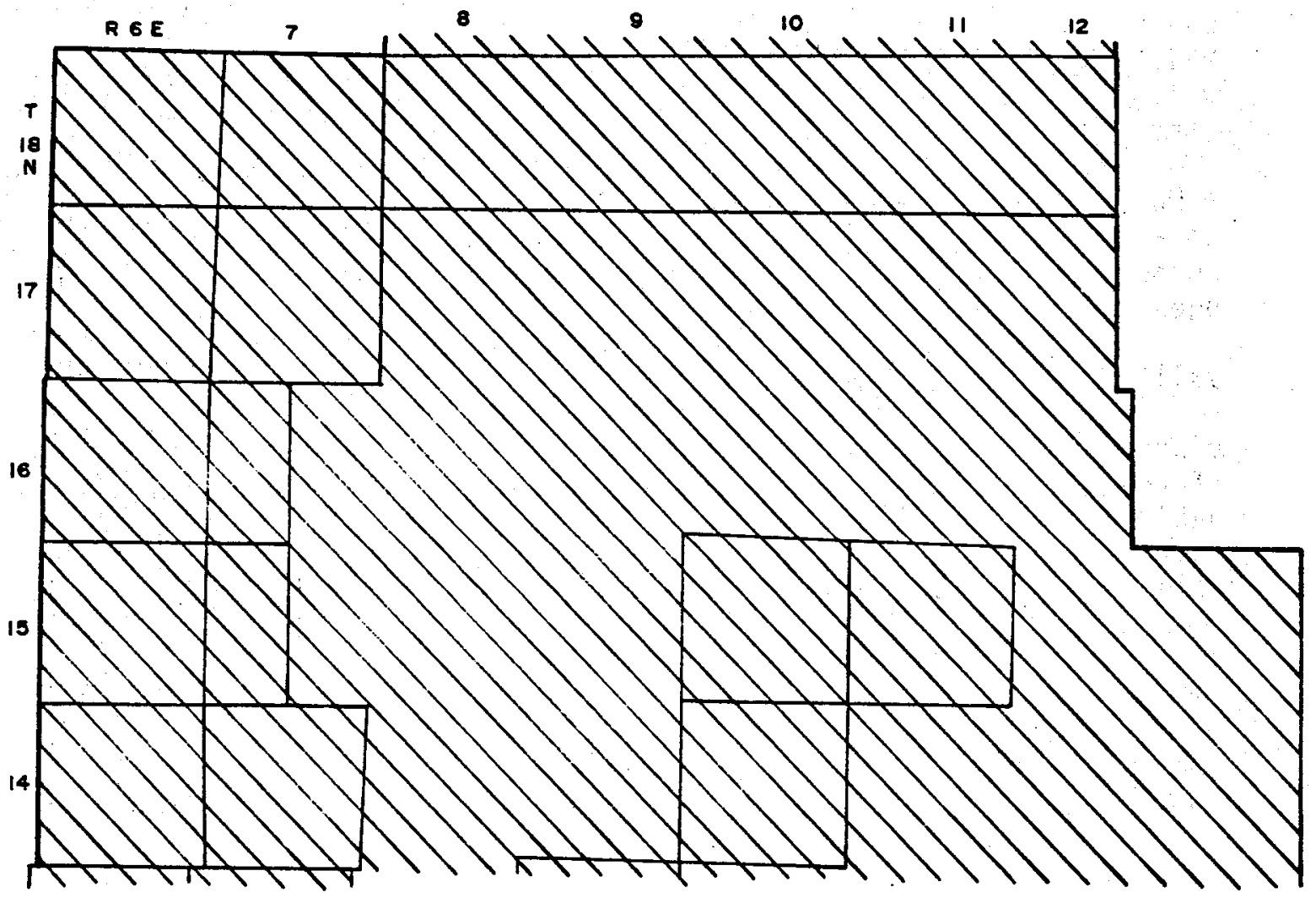

LEGEND

LaNDS VALUABLE PROSPECTIVEIY for
GeOthermal RESOURCES

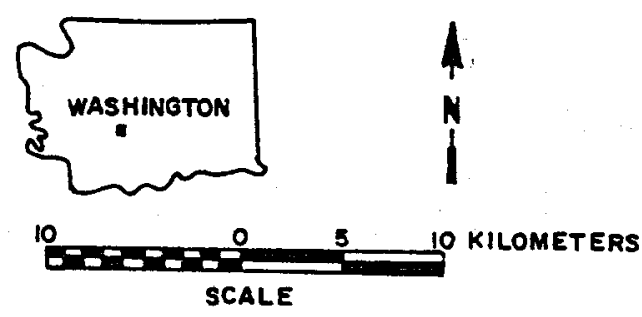




\section{MOUNT RAINIER PGRA}

\section{Introduction}

The Mount Rainier PGRA includes some 829,440 acres, situated in and around Mount Rainier National Park. The study area is ca. $115 \mathrm{~km}$ southeast of Tacoma, Washington.

The area has been classified as a "PGRA" or Potential Geothermal Resource Area by the U.S. Geological Survey. The area is considered to be one of the prime geothermal prospects in the state of Washington based upon its position within the Cascade Range, the presence of the largest volcanic cone in the continental United States, and three thermal spring areas that are thought to be associated with the volcanic process of Mount Rainier.

The three thermal springs include: Ohanapecosh Hot Springs, Summit Creek Mineral Springs (Soda Springs), and Longmire Mineral Springs. Surface temperatures of the springs are 10w, except at Ohanapecosh Hot Spring. However, estimated reservoir temperatures as calculated from geochemical analysis are in the range of $130^{\circ}$ to $170^{\circ} \mathrm{C}$.

The rectilinear location of the three thermal spring areas is as follows: Ohanapecosh Hot Springs, NW1/4NW7/4 sec. 4, T. 14 N., R. 10 E.; Summit Creek Mineral Springs (Soda Springs), NW1/4SW1/4 sec. 18, T. 14 N., R. 11 E.; and Longmire Mineral Springs, SEl/4SEl/4 sec. 29, T. 15 N., R. 8 E.

Land ownership is ca. 29.2 percent, national park service, ca. 43.3 percent, national forest; ca. 2.5 percent state; and ca. 11.6 percent private. National park land is excluded from leasing and private development by the Geothermal Steam Act of 1970, and any potential development of the resource within the park will be restricted to uses by the park service.

The Mount Rainier PGRA is dominated topographically by Mount Rainier, with an elevation of $4,392 \mathrm{~m}$. The total study area is within the Cascade Range province, and much of the area is characterized by steep ridges and deep canyons. Glaciers that reach elevations $1,200 \mathrm{~m}$ feed several rivers in the area. The main rivers include the Ohanapecosh, Puyallup, Cowlitz, American, Nisqually, White, and Bumping.

The nearest communities to the study area are Packwood, ca. $13 \mathrm{~km}$, Ashford, ca. $3 \mathrm{~km}$, and Carbonado, ca. $5 \mathrm{~km}$. Tacoma with some 156,000 inhabitants, is ca. $115 \mathrm{~km}$ to the northwest. Local potential use of any resource, which could be developed, would be limited to the space heating of small communities and to uses within the limited number of timber product manufacturers that are found in the immediate vicinity. Uses by the park service for the space heating of park facilities could become a major use of the resource. The potential for the transportation of geothermal fluid to major population and industrial centers such as Tacoma cannot be determined until such time as the quantity and quality of the resource is established. 
Very little is known about the potential for development of geothermal resources in the study area as little geological assessment work has been completed and that which has been done by private companies has not been released to the public.

Estimates of reservoir temperatures that have been made by the use of geochemical thermometers are in the range $130^{\circ}$ to $170^{\circ} \mathrm{C}$. A full geological and geophysical assessment is needed before estimates of reservoir temperatures, aerial extent of the reservoir, and recoverable energy are made. An assessment of this type will take serveral years even if funds are made available for this purpose. If at the end of such an assessment program, it is concluded that an economically recoverable resource is present, it would take until the latter half of the 1980's before the area could be producing. A full assessment of potential utilization of the resource is at present impossible due to the lack of detailed information concerning the quality and quantity of the resource. It does appear that within the range presented by geothermometers that space and greenhouse heating would be possible. Both these uses have been found to be economically competitive with existing energy types at several locations including: Reykjavik, Iceland; Boise, Idaho; and Klamath Falls, Oregon, to name a few. Other potential uses include preheating of industrial waters, drying of timber produces, and at the upper end of the temperature range, electrical generation by a binary process.

This area at one time had developed resorts based on the presence of the thermal springs at Longmire Mineral Springs and Ohanapecosh Hot Springs. Both of these areas are now within the boundaries of Mount Rainier National Park, and the park service has allowed both areas to return to nature.

Over the past years, a renewed interest has occurred, and a number of geothermal lease applications are now on file with the BLM office in Portland, Oregon. Since the filing of lease applications, AMAX Corporation has done some heat flow drilling in the area of Summit creek Mineral Springs (Soda Springs). Unfortunately, results of the work by AMAX have not been released to the public. At present, the U.S. Geological Survey is drawing up plans in cooperation with the State of Washington Division of Geology and Earth Resources for the geothermal assessment of the Cascade Range over the next 3 to 5 years. It is not known, however, at what point during the program that Mount Rainier will be the focus of assessment work.

Continued assessment by private companies is not expected to take place until the granting of leases by BLM. Leasing has been, and continues to be, held up until such time as the forest service completes an environmental statement concerning geothermal leasing and development of the area. The completion of such an environmental statement is not expected until at least the early 1980's. Any environmental statement will not consider areas within Mount Rainier National Park; as previously stated, geothermal leasing and development by the public sector is not allowed under provisions of the Geothermal Steam Act of 1970 in national parks.

Major portions of the study area are located within the boundaries of Mount Rainier National Park, and are excluded from potential development 
except for uses that the park service may deem acceptable. These uses would most surely be limited to the space heating of existing or future facilities within the park. Although this potential exists, the park service has to date expressed a lack of interest in examining the feasibility of such actions.

Very little is known about public attitudes toward geothermal development in the study area. However, public concern for the preservation of the environment is strong in the state. In addition, concerns of the park service and the forest service are known to be strongly antidevelopmental and must be considered to be over-riding in this instance. 
SITE DATA SUMMARY

SITE: Mount Rainier PGRA

. Physical Reservoir Data

. Temperature ${ }^{\circ} \mathrm{C}$

Surface: $21^{\circ}-75^{\circ} \mathrm{C}$ (Schuster et al, 1978).

Subsurface: Na-K-Ca $93^{\circ}-172^{\circ} \mathrm{C}$ (Schuster et al, 1978).

. Total Dissolved Solids (PPM): Ca. 2,100 to 5,100 (Schuster et al, 1978):

..Estimated Non-Electric Energy Potential (MBtuh 30 years): No estimate is possible at this time.

..Type of Overlying Rock: Volcanic (Huntting et al, 1961). ... Estimated Depth to Top of Reservoir (meters): No estimate is available.

.. Site Land Status

$\begin{array}{lllll} & \text { FED. } & \text { STATE } & \text { PRIVATE } & \text { OTHER } \\ \text { Total Acres } & 712,488 & 20,736 & 96,215 & \\ \text { Total Acres Leased } & \text { None } & \text { None } & \text { None } & \text { None }\end{array}$

..Geothermal Development Status: There is at present no geothermal development in the Mount Rainier area. At one time Ohanapecosh Hot Springs and Longmire Mineral Springs experienced some development, but the forest service has allowed the areas to go back to nature.

..Local and State Attitude Toward Geothermal Development: At the present time the Washington State Department of Natural Resources and the Washington State Energy Office are in the process of developing a statewide plan for geothermal assessment and development. The area surrounding Mount Rainier National Park is one of several areas of great interest. Interest in the area stems from the known hot springs and from the closeness of Mount Rainier, one of the major stratovolcanoes in the state.

Environmental issues will have great importance in the area because any development would have to be within short distances of Mount Rainier National Park.

..Land Use and Population: The majority of the land surrounding Mount Rainier is in Mount Rainier National Park and is open to recreational or educational uses only. Surrounding the park is national forest. land in either the Gifford Pinchot National Forest or the Mount Baker-Snoqualmie National Forest, and the primary use is timber production and recreation (U.S. Forest Service, Gifford Pinchot National Forest Map, 1976; U.S. Forest Service, Mount Baker-Snoqualmie National Forest Map, 1978). 
Population density in the area is low, and concentrated only in recreational areas. Distances to major population centers in considerable (Washington State Highway Commission Map, 1975).

..Comments and Critical Issues: The area located within the boundaries of Mount Rainier National Park must be eliminated from considerations for development as this area is excluded by the Geothermal Steam Act of 1970 (Appendix I). Development outside the park on private lands or within the national forests will be extremely environmentally sensitive. A great deal of geologic assessment is needed before the area can be seriously considered. 
. Latitude: $46^{\circ} 51^{\prime} \mathrm{N}$.

..Longitude: $127^{\circ} 45^{\prime} \mathrm{W}$

.Rectilinear: T. 15 N., R. 8 E.

(Mount Rainier quadrangle, 30-minute series, 1928)

..County: Pierce

.Adjacent Counties: King, Yakima, Lewis, and Thurston (Washington State Highway Commission Map, 1975).

. Topography: The area is in the high Cascades with elevations up to $4,392 \mathrm{~m}(14,410$ feet). Much of the area is covered by steep ridges and deep canyons; some canyons contain major glaciers down to $1,200 \mathrm{~m}(4,000$ feet). Several lakes of glacial origin are present (Mount Rainier quadrangle, 30-minute series, 1928).

..Present Land Use: Land within the boundaries of Mount Rainier National Park is restricted to recreation and educational uses. Land use in the two national forests which surround the park is predominately timber production and recreation. Some minor farming occurs on the private land to the west of the park.

..Future Land Use Plans: It is expected that timber production and recreation will remain dominant on the national forest lands. Within the park boundaries, land use is restricted to recreational and education uses by the national park status.

.Aesthetics: This is an area of extremely high aesthetic value. The aesthetic experience is paramount to the majority of the visitors to Mount Rainier National Park, and to visitors to the surrounding forest service lands. The park is reached by numerous roads and there is a well-developed road system within the park. Also, a great number of trails cross the area, which contains numerous glaciers, lakes, high mountain meadows, streams, waterfalls, and interesting geologic areas (Wheeler, 1978).

..Historical/Archaeological Significance: There are no known archeological sites in the Mount Rainier area and no site of historical significance as determined by the National Historical Register is in the area (Odegaard, 1976).

However, the lodges at both Longmire and Paradise have been discussed as possibles for inclusion in the National Historical Register. 
..Geologic Description: Mount Rainier, which has an elevation of 4,392 $\mathrm{m}(14,410$ feet), is composed chiefly of flows of pyroxene andesite and was built upon an earlier mountainous surface, carved from al tered volcanic and sedimentary rocks, which had been invaded by plutonic and hypabyssal igneous rocks.

The oldest rocks, which reach a thickness of $3,050 \mathrm{~m}(10,000$ feet $)$, comprise the Ohanapecosh Formation of late Eocene age. The Ohanapecosh Formation includes lensoid accumulations of lava and coarse mudflows, heaped around volcanic centers. These centers are in turn surrounded by vastly greater volumes of volcaniclastic rocks, in which $10 \mathrm{~m}$ (33 feet) beds of unstratified tuff breccia alternate with thin-bedded breccias, sandstones, and siltstones composed entirely of volcanic debris. The coarse tuff breccias were most likely deposited from subaqueous volcanic mudflows generated when clouds of eruptive materials were discharged directly into water, or when subaerial ash flows and mudflows entered bodies of water. Also included are lava flows and coarser lava fragments, mostly andesite, but with dacite, basalt, and rhyolite.

The Ohanapecosh Formation was then folded and metamorphosed to zeolite facies before being uplifted and eroded.

Overlying the Ohanapecosh Formation is the Stevens Ridge Formation, consisting of $1,000 \mathrm{~m}(3,300$ feet $)$ of 01 igocene and Miocene ash flows. These massive ash flows consist primarily of rhyodacite pumice lapilli and glass shards.

The Fifes Peak Formation of early Miocene age overlies the Stevens Ridge Formation, and consists of lava flows, subordinate mudflows, and minor quantities of tuffaceous clastic rocks, including basalt, basaltic andesite, and some rhyolite. Swarms of diabase sills and dikes in the area are believed to be the intrusive equivalent of the Fifes Peak Formation.

The Fifes Peak Formation, as we1l as the Stevens Ridge and Ohanapecosh Formations, was extensively folded, faulted, and uplifted and then eroded before the late Miocene Tatoosh pluton worked its way upward to shallow depths and eventually to the surface.

Deep erosion of the Tatoosh pluton occurred before the first Mount Rainier flows were extruded in early Pleistocene. These were voluminous lava flows of pyroxene andesite. Eventually, overlapping streams of lava, subordinate mudflows, and thin pyroclastic deposits built a huge cone that was ca. $300 \mathrm{~m}(1,000$ feet) higher than the present mountain (Fiske et al, 1963).

The present summit is formed by a Holocene cone of glassy black hypersthene andesite that lies within and partly fills a broad depression at the top of the volcano that was formed ca. 5,000 years. B.P. by phreatic explosions, avalanches, and glacial erosion of the original summit (Moxham, 1970). 
..Geophysical Summary: During a period from July 13 to August 11,1968 , a seismic net was used to measure the seismic activity on Mount Rainier. During this period, approximately 345 microearthquakes were detected. About 80 percent of the recorded microearthquakes were in a roughly concentric pattern around the western side of the volcano, at depths ranging from 0.5 to $15 \mathrm{~km}$; 8 percent of the microearthquakes were beneath the summit crater, at depths ranging form 0.2 to $20 \mathrm{~km}$. Seventy-five percent of the microearthquakes were at depths of less than $5 \mathrm{~km}$. Daily counts ranged from 5 to 16 microearthquakes (Unger and Decker, 1970).

In 1969, additional studies were made of micorearthquake activity. It was concluded at this time that most of the epicenters are quite scattered and do not fall into any definite patterns, such as the linear alignments that one might expect to find along an active fault.

It was furthermore concluded that almost all of the earthquakes that were located appear not to be directly associated with any volcanic processes, and therefore, most of the events measured were a sampling of the tectonic background seismicity of the region (Unger and Mi11s, 1972).

Infrared surveys in September 1964 and September 1966 show no substantial changes in the thermal patterns at the summit of Mount Rainier.

The highest apparent temperatures were recorded along a narrow arc coinciding with the northwestern rim of the east summit crater. Toward the northwest end of the arc, the thermal pattern widens and apparently bifurcates southwestward, resulting in four thermal lineaments in the crater wall. A similar accurate thermal pattern was recorded on the northwest quadrant of the west crater rim, and a complex reticulation of anomalies extended down the northwest slope from the west crater. The volcano's central axis and presumably the central plug are northwest of the summit craters. The location of the thermal patterns at the summit, with maximum intensity in the northwest quadrants, suggest the possibility that the volcanic plug and presumed primary source of heat at depth is centered northwest of the present summit. It was further concluded, on the basis of the 1964 IR survey, that the highest apparent temperatures and most well-defined peripheral thermal arc were associated with the northwest side of the youngest crater, which lies farthest from the axis of the central plug. The west crater had somewhat lower apparent temperatures and was less well defined thermally than the east crater (Moxham, 1970).

..Geologic Hazards: Although the volcano as we now know it was almost completely formed before the last major glacial period, geologic formations record a variety of events that occurred at Mount Rainier in postglacial time. A repetition of some of these events without warning would result in property damage and most likely loss of 1 ife on a scale that could be catastrophic.

Folsom (1970) places probable volcanic events associated with Mount Rainier between 1800 and 1875 (1843, 1854, 1858, 1870 and an undetermined date between 1820-1854). 
Hopson et al., 1962, report that on the basis of tree-ring data, as well as radiocarbon data, the youngest ash blanket from Mount Rainier was deposited about 550-600 years ago. They conclude, on the basis of the above, that Mount Rainier apparently has not erupted within the period since the area was settled by white men and that the pumice and ash sheet represents its most recent outburst at about 550-600 years B.P.

The types of geologic hazards can be divided in lava flows, pyroclastic eruptions, and debris flows. Lava flows would not be expected to cause considerable damage but could cause debris flows, which could originate from the melting of large masses of snow and ice. Eruptions of pumice even on a large scale would in most cases be troublesome but not cause catastrophic results unless they were to trigger a debris flow.

Debris flows can be caused directly or indirectly by volcanic eruptions. Some may start in large landslides triggered by earthquakes or volcanic explosions, and others may be created by the spillover of a crater lake or by an eruption of hot volcanic debris or lava onto ice and snow, which causes large floods and the removal of loose debris on the flanks of the volcano. Mudflows may also originate as in glacial outburst floods or during periods of exceptionally heavy rainfall.

Several debris flows have moved down the flank of Mount Rainier over the past 5,000 years. The 0sceola Mudflow traveled 40 miles and covered 65 square miles of the Puget Sound Lowland. It submerged the White River valley, at the site of the White River campground, beneath 500 feet of mud and rock debris. It also buried the sites of the present communities of Enumclaw and Buckley under as much as $21.3 \mathrm{~m}(70 \mathrm{ft}$.) of mud. 0ther major flows have moved down the South Puyallup River, Tahoma Creek, and the Puyallup River (Crandell and Mullineaux, 1976). It can be concluded that the greatest danger exists from debris flow which could occur on the average of once every century. 


\section{RESERVOIR CHARACTERISTICS}

. Reservoir Temperature

..Surface: $21^{\circ}-75^{\circ} \mathrm{C}$ (Schuster et az. 1978) Numerous steam vents and ice caves are located in the summit crater (Unger and Decker, 1970).

. Subsurface: No information is available.

..Geochemical

$\mathrm{SiO}_{2}: 125^{\circ}-168^{\circ} \mathrm{C}$

$\mathrm{Na}-\mathrm{R}-\mathrm{Ca}: \quad 93^{\circ}-168^{\circ} \mathrm{C}$

(Schuster et al. 1978)

..Flow Rates: 0.19 to $3.781 / \mathrm{s}$ (Schuster et al. 1978)

..pH: 6.0-7.9 (Schuster et al. 1978)

..Total Dissolved Solids: Approximately 2,100 ppm to 5,100 ppm (Schuster et az. 1978)

..Fluid Chemistry:

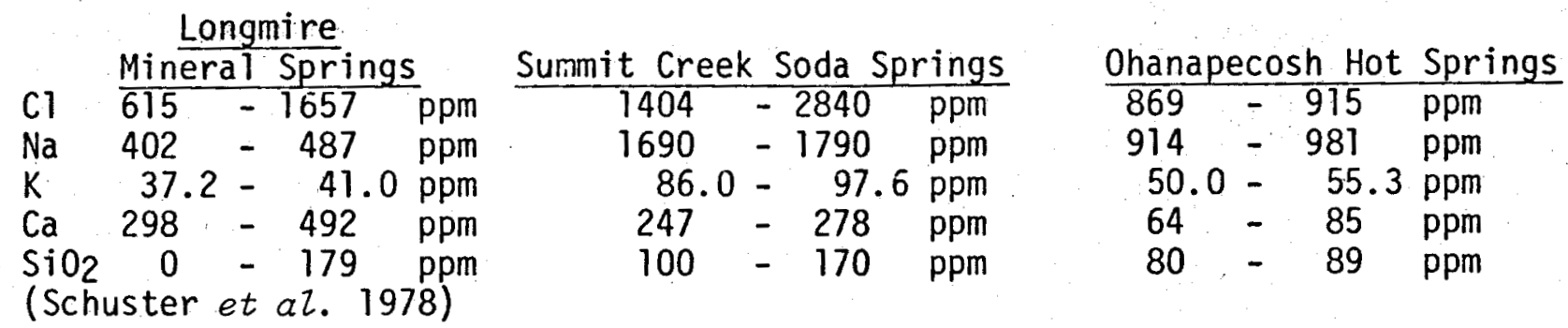

..Estimated Nonelectric Energy Potential (MBtuh 30 years): No estimate is possible at this time.

. Subsurface Area of Reservoir: No estimate is possible at this time. 


\begin{tabular}{|c|c|c|c|}
\hline $\begin{array}{l}\text { TOTAL AREA } \\
\text { (Acres) }\end{array}$ & $\begin{array}{l}\text { FEDERAL } \\
\text { (Acres) }\end{array}$ & $\begin{array}{l}\text { STATE } \\
\text { (Acres) }\end{array}$ & $\begin{array}{l}\text { PRIVATE } \\
\text { (Acres) }\end{array}$ \\
\hline
\end{tabular}

..Land Ownership $\quad 829,440, \quad 712,488 \quad 20,736 \quad 96,215$

.. Land Leased

None

None None

None

None

..Highest Priced

Leases (Dollars/

Acres)

N/A

N/A

N/A

N/A

N/A

..\$/Acre Lessee

$$
\text { N/A N/A }
$$

..Tentative Lease

Sale Dates:

N/A

N/A

$N / A$

N/A

N/A

.. Number of Sales

offered but no Bids: N/A

N/A N/A

N/A

N/A

. Number of Bids Rejected

(Resulting in No Lease): N/A

..Summary of Leasing Status and Needs: Leasing within Mount Rainier National Part is, under provisions of present laws, impossible (Appendix I). Leasing of national forest lands is under the jurisdiction of $B L M$, but cannot take place until an environmental statement is prepared and okayed by the forest service. At the present time no environmental statement is being completed by the forest service and none is planned.

No provisions for the leasing of state and private lands has been made under Washington 1 aw. 
..Present Development Status: At present there is no geothermal development in the Mount Rainier area. At one time Ohanapecosh Hot Springs and Longmire Mineral Springs experienced some development, but the park service has allowed the area to go back to nature.

..Projected or Planned Development: There is no planned or projected geothermal development in the area at this time. Geothermal development within Mount Rainier National Park would be expected to be limited to space heating of Paradise and Longmire facilities. Development in areas surrounding the park will depend upon the forest service leasing the land. No leasing can begin until such time as an environmental statement is planned. 


\section{INSTITUTIONAL CHARACTERISTICS}

.. Institutional Requirements: The Geothermal Steam Act of 1970 (Appendix I) excludes national park land from private leasing.

Forest service lands cannot be leased until after the preparation and acceptance of an environmental statement covering the lands in question.

The question of ownership of geothermal resources on state and private lands, as well as the leasing of state lands, is at present under consideration.

.Agency and Public Attitudes: It is not known what the feeling toward geothermal development is by the Mount Rainier National Park Superintendent.

Environmental statements for geothermal leasing have been receiving low priority from the forest service, and no statement is proposed for this area.

The Washington Department of Natural Resources and the Washington Energy office are at present very interested in developing plans for geologic assessment and the eventual development of geothermal resources in the state.

..Status of Requirements (i.e., EIA/EIS Requirements): No plans are now under consideration concerning the preparation of an environmental statement for geothermal leasing on the federal lands concerned. At present the state Interagency Geothermal Development Council is looking into various alternative suggestions concerning ownership of the resource and the leasing of state lands. It is hoped that it will be possible to have the requirements accepted and leasing procedures developed within the next two years. 


\section{ENVIRONMENTAL FACTORS}

. Climate

..Prevailing Winds: Winds are from the west to south southwest (Phillips, 1968).

..Precipitation (Annual): Mean annual precipitation at Longmire is $2,093.7 \mathrm{~mm}$ (82.43 inches) and at Paradise it is 2,666.2 mm (104.97 inches). Highest precipitation is from November to February (Phillips, 1968).

..Days of Sunshine (Annual): No information is available. . Average Temperature: Mean annual temperature is $7.28^{\circ} \mathrm{C}\left(45.1^{\circ} \mathrm{F}\right)$ at Longmire and $3.50^{\circ} \mathrm{C}\left(38.3^{\circ} \mathrm{F}\right)$ at Paradise (Phillips, 1968).

Minimum: Mean minimum temperature at Longmire is $1.83^{\circ} \mathrm{C}$ $\left(35.3^{\circ} \mathrm{F}\right)$ and $-0.94^{\circ} \mathrm{C}\left(30.3^{\circ} \mathrm{F}\right)$ at Paradise (Phillips, 1968).

Maximum: Mean maximum temperature at Longmire is $12.78^{\circ} \mathrm{C}$

$\left(55.0^{\circ} \mathrm{F}\right)$ and $7.89^{\circ} \mathrm{C}\left(46.2^{\circ} \mathrm{F}\right)$ at Paradise (Phillips, 1968).

.Degree Days (Annua:1): Longmire has 7,253 heating degree days on a base $18.3^{\circ} \mathrm{C}\left(65^{\circ} \mathrm{F}\right)$ and Paradise has 9,560 (Phillips, 1968).

. Relative Humidity (Seasonal Peaks):

Summer: $04^{\circ \circ} 87$ percent $16^{\circ \circ} 60$ percent

Winter: $04^{\circ 0} 93$ percent $16^{\circ 0} 91$ percent (Phillips, 1968)

. Air quality: Air quality is very high. Main pollutants are particulates in the form of dust or at times may come from forest fires and slash burning.

..Geologic Factors: The main geologic factors of environmental interest are slope stability problems, and events which would be expected to accompany volcanic activity. Of primary concern would be debris flows as a result of the melting of large amounts of ice and snow (Crandell and Mullineaux, 1967).

..Water Quality: The quality is very high. Streams in the area are rated as Class AA (extraordinary). (Washington Administrative Code [WAC] Chapter 173-201 WAC: James, personal communication, 1978)

. Noise: Ambient noise levels are low. Main sources of noise are logging in surrounding areas and vehicle noises from the various routes through the area.

..Biological

..Dominant Flora: The mountain itself is in the zone of ArcticAlpine vegetation and the surrounding area is dominated by the Hudsonian and Canadian species. 
The Arctic-Alpine species include: Juniperus sibirica, Salix cascadensis, Salix nivalis, Gaultheria humifusa, Empetrum nigrum, and the heathers Phylzodoce glanduliflora, Cassiope mertensiana, and Cassiope stelzeriana.

The Hudsonian species include: alpine fir Abies Zasiocarpa, mountain hemlock Tsuga mertensiana. Alaska cedar Chamaecyparis nootkatensis, and white-barked pine Pinus albicaulis. Common shrubs are salix barclayi, Salix commutata, Juniperus sibirica, Alnus sinuata, Ribes howellii, Lutkea pectinata, Potentilla fruticosa, Sorbus ocaidentalis, Spiraea densiflora, Pachistima myrsinites, Arctostaphylos nevadensis, Arctostaphylos uva-ursi, Cassiope mertensiana, Cassiope stelleriana, Phyllodoce empetriformis, Rhododendron albiflom, and Gaultheria ovalifolia.

Canadian species include: Douglas fir Pseudotsuga taxifolia, western hemlock Tsuga heterophylza, amabaslis fir Abies amabalis, white pine Pinus montecola, and noble fir Abies nobizis. Other plants include Vaccinnium ovalifolium, Vaccinnium membranaceum, Menziesia ferruginea, Alnus sinuata, Acer circinatum, Sorbus cascadensis, Cornus canadensis, Clintonia uniflora, Stenauthium occidentale, Galium oreganum, and Prenanthes lessingii. Saprophytes are abundant in this zone (U.S. Army Corps of Engineers, 1973).

..Dominant Fauna: Dominant species include: black bear, elk, black-tailed deer, beaver, raccoon, mink, muskrat, river otter, bobcat, cougar, snowshoe hare, chickaree, white-footed deer mouse, cinereous shrew Sorex cinereus cincereus, fisher Martes pennanti, red fox Vulpes fulva cascadensis, wolf Canis lupus fuscus, Canada lynx Lynx canadensis, long-eared myotis Myotis evotis pacificus, mountain goat, blue grouse, white tailed ptarmigan, and spruce (Franklin) grouse (U.S. Army Corps of Engineers, 1973).

... Endangered, Rare, Remnant, Unique Or Otherwise Significant Species:

..Flora: Tree specimens--Evergreen: Alaska cedar Chamaecyparis nootkatensis and grand fir Abies grandis (U.S. Army Corps of Engineers, 1973).

-Fauna: American peregrine falcon Falco peregrinus anatum (endangered). mountain lion Felis concolor, fisher Martes pennanti, wolverine GuZo Zuscus Zusteus, Canada Iynx Lynx canadensis, mountain goat Oreamis americanus, wolf Canis Zupus fuscus and northern white-tailed ptarmigan Lagopus Zeucurus leucurus. The area also includes important elk range and anadromous fish routes Salmonid. The Butter Creek Research National Area is found in the southern part of the Mount Rainier National Park (U.S. Army Corps of Engineers, 1973). 
..Utility Or Energy Transmission Corridors And Facilities:

Two $115 \mathrm{KV}$ lines approximately $20 \mathrm{~km}$ (12.5. miles) west - owned by Tacoma City Light

One $55 \mathrm{KV} 1$ ine approximately $17 \mathrm{~km}$ (10.5 miles) west - owned by Puget Sound Power and light.

One low voltage line to Longmire and Paradise.

One $69 \mathrm{KV}$ line approximately $24 \mathrm{~km}$ ( 14.9 miles) south - owned by Lewis County PUD

(BPA Area Office Map, sheet 5, 1974 and BPA Area Office Map, sheet 8, 1974)

..Transportation Corridors Or Facilities: Main transportation routes include state routes $165,706,123$ and 410 , a11 reach the Mount Rainier National Park boundaries. In addition to the above state routes, numerous forest service routes serve the surrounding forest service lands (Washington State Highway Commission Map, 1975; Gifford Pinchot National Forest Map, 1976; and U.S. Forest Service Mount Baker-Snoqualmie National Forest Map, 1978). 


\section{POPULATION}

. General Description of Population: Population levels in the area are low, and major population centers such as Auburn, Kent, Renton, Puyallup, and Tacoma are at considerable distances from potential resource areas.

Population levels have been increasing slowly in the counties surrounding the study area over the past decade.

Employment is concentrated in the manufacturing, retail trade, and services industries. Major industries include timber products, smelting and petro-chemicals (Rocket Research Corp. 1977; Washington Office of Financial Management, 1977).

.. Economics:

. Present Land Use: The principal land use in the Mount Rainier National Park is recreation. Outside the park on national forest lands, timber production and recreation are of primary importance. To the west, agriculture activities play a small role. Timber production as well as tourist-related industries, employs the largest number of individuals in the study area.

..Future Land Use: Significant changes in land use patterns are not expected to occur. 
$(-)$

$\mathcal{U}$ 
KENNEDY HOT SPRINGS KGRA 
FIGURE 8- GEOTHERMAL LAND CLASSIFICATION MAP

KENNEDY HOT SPRINGS KGRA

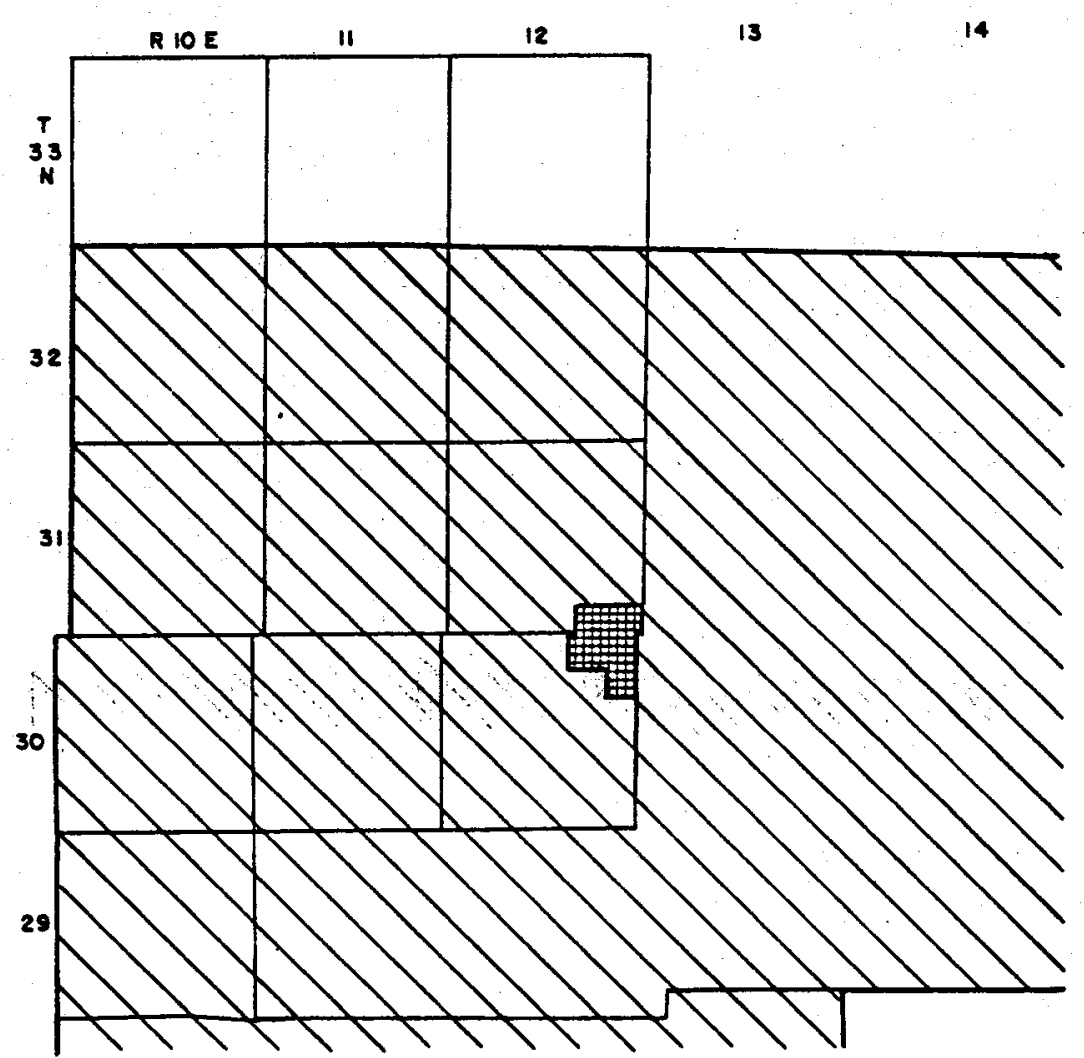

\section{LEGEND}

\section{1}

KNOWN GEOTHERMAL RESOURCES AREA

$\square$
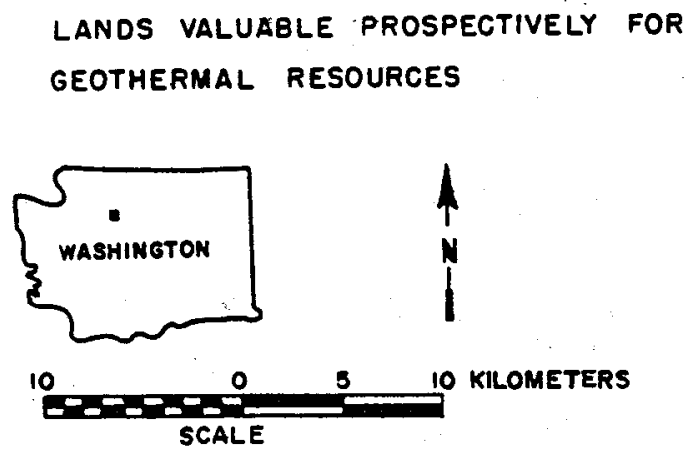

Base map: U.S. Geological Survey Geothermal Land Classification Map, Wosnington, 1974 
KENNEDY HOT SPRINGS KGRA

Introduction

The Kennedy Hot Springs KGRA (Known Geothermal Resource Area) is comprised of some 3,311 acres in the Glacier Peak Wilderness Area. The KGRA is part of the much larger Glacier Peak PGRA (Potential Geothermal Resource Area) which contains 460,800 acres. Of this total, 437,760 acres are under the management of the Snoqulamie National Forest Service, and in this total are 230,400 acres of the Glacier Peak Wilderness Area. Ca. 23,040 acres are under state and private ownership.

The study area is in the southern portion of the North Cascades ca. 30 $\mathrm{km}$ (19 miles) southeast of Darrington, Washington. The area is in Snohomish County.

The study area, although designated as a KGRA by the U.S. Geological Survey, is not considered to be one of the top prospects in the state. The entire KGRA is within the boundaries of the Glacier Peak Wilderness Area and closed to leasing and development by provisions of the Geothermal Steam Act of 1970 (Appendix I).

Because of the wilderness status of the KGRA, any discussion of the potential use of any resource which might exist in the KGRA is felt to be inappropriate at this time, and only baseline data from the area has been collected.

The study area will, however, be assessed during the next 3 to 5 years as part of the Cascades Geothermal Assessment Program which is being funded jointly by the U.S. Geological Survey and the U.S. Department of Energy. The assessment program is presently being developed by the U.S. Geological Survey in cooperation with the Washington Division of Geology and Earth Resources. It is not presently known when the focus of the program will be directed towards the northern Cascades and in particular to the Glacier Peak area.

Consideration will be given by the author to areas in the Glacier Peak PGRA which lie outside the Glacier Peak Wilderness Area at some latter point in the program. 
SITE DATA SUMMARY

SITE: Kennedy Hot Springs KGRA

..Physical Reservoir Data

. Temperature ${ }^{\circ} \mathrm{C}$

Surface: $21^{\circ}-38^{\circ} \mathrm{C}$ (Schuster et az., 1978)

Subsurface: $186^{\circ}-207^{\circ} \mathrm{C}$ (estimated from $\mathrm{Na}-\mathrm{K}-\mathrm{Ca}$ )(Schuster et al., 1978)

..Total Dissolved Solids (PPM): Ca. 2,000 ppm (Schuster et al., 1978)

..Estimated Non-Electric Energy Potential (MBtuh 30 years): No estimate is possible at this time.

. Type of Overlying Rock: Pleistocene and Recent volcanics overlying Tertiary and Cretaceous granitic intrusions and Jurassic metamorphics. (Huntting et ar., 1961)

..Estimated Depth to Top of Reservoir (meters): No estimate is possible at this time.

.. Site Land Status

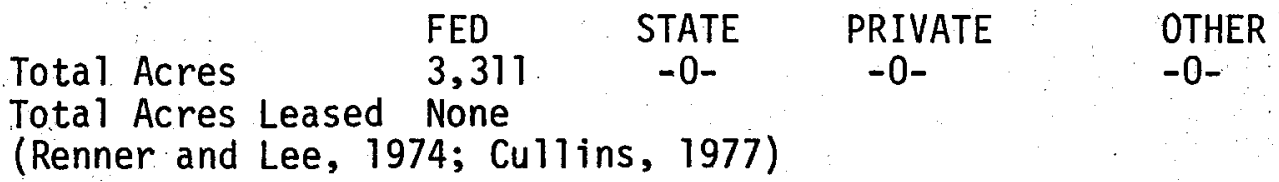

..Geothermal Development Status: Development at the site is severely limited due to its Tocation in the Glacier Peak Wilderness Area (Appendix I). (U.S. Forest Service, Mount Baker-Snoqulamie National Forest Map, 1978)

- Local and State Attitude Toward Geothermal Development: There is a high degree of interest in exploration in the area by the Washington State Department of Natural Resources. Development is expected to be limited by the location within the wilderness area and by environmental concerns.

..Land Use and Population: The area is open forests in the high Cascade Mountains. Ma in land use is recreation. Timber harvesting takes place outside the wilderness area. There are no permanent population sites within the KGRA because of the wilderness status of the area.

..Comments and Critical Issues: Kennedy Hot Springs, as well as the entire KGRA, is within the boundaries of the Glacier Peak Wilderness Area.

Legal restrictions on development activities within a wilderness area (Appendix I), environmental concerns, and the distance to large population centers are all critical to eventual development in the area. 
SITE LOCATION AND PHYSICAL DESCRIPTION

..Latitude: $48^{\circ} 07^{\prime} \mathrm{N}$

. Longitude: $121^{\circ} 12^{\prime} \mathrm{W}$

..Rectilinear: NEl/4 section 1, T. 30 N., R. 12 E.

(Renner and Lee, 1974; Glacier Peak quadrangle, 15-minute series, 1950)

..County: Snohomish

. Adjacent Counties: Skagit, Chelan, King (Washington State Highway Commission Map, 1975)

..Land Ownership: U.S. Forest Service (U.S. Forest Service, Mount Baker-Snoqualmie National Forest Map, 1978)

. Topography: High Cascade Mountains with elevations from 880 meters $(2,887 \mathrm{ft}$. $)$ to 1,935 meters $(6,348 \mathrm{ft}$.$) . Several glacial lakes are$ found within the KGRA (Glacier Peak quadrangle, 15-minute series, 1950).

..Present Land Use: Forest and woodlands in Glacier Peak Wilderness Area. Present land use is restricted to recreation (Taylor, personal communication, 1978)

..Future Land Use Plans: Continued recreational uses are expected to dominate. (Taylor, personal communication, 1978)

..Aesthetics: The area has a very high aesthetic value. The aesthetic value of the area is of great importance because of the number of trails which cross the wilderness area, including the Pacific Crest Trail. (U.S. Forest Service, Mount Baker-Snoqualmie National Forest Map, 1978)

..Historical/Archaeological Significance: There are no known historical or archaeological sites in the area, but no thorough archaeological

study has been made. (Odegaard, 1976; U.S. Forest Service, Mount BakerSnoqualmie National Forest Map, 1978) 
.Geologic Description: There have been three principal episodes of Cenozoic igneous activity in the Glacier Peak area. The three episodes include the intrusion of the tonalite-granodiorite cloudy Pass batholith in early Miocene time, which has been dated radiometrically at 22 m.y. (million years); the extrusion of a thick sequence of predominantly andesitic to dacitic breccia, tuff, and lava of Gamma Ridge between early Miocene and Pleistocene time on or near the exposed batholith; and in late Pleistocene and Recent time, the growth of the dacitic Glacier Peak volcano which was accompanied by the eruption of small amounts of basalt from separate vents near Glacier Peak.

The volcano began to grow in a mountainous terrain approximately 700,000 years ago and last erupted about 12,000 B.P. The volcanic cone consists almost entirely of flows of clinopyroxene-hypersthene dacite with very little pyroclastic material present. The aggregate thickness of the Glacier Peak lava flows nowhere exceeds $750 \mathrm{~m}$ (ca. 2,500 ft.). Thus, with a total height of $3,185 \mathrm{~m}(10,451 \mathrm{ft}$.$) , it can readily be seen that$ the cone is built upon a high bedrock ridge of older material.

In the latest phase of volcanic activity, which occurred ca. 12,000 years ago, eruptions of pumice and associated mudfiows as well as a nuee ardente took place.

Besides Kennedy Hot Springs, two hot springs, Sulphur and Gamma, are present, and are the only present evidence that hot rocks and perhaps magma still exist at depth.

The three hot springs issue from the following bedrock types: Kennedy, biotite gneiss cut by dikes and sills of leucocratic tonalite; Gamma, dacite to rhyodacite tuffs highly altered near the springs; and Sulphur, quartz-mica schist with layers of hornblende schist.

The predominant structures of the Glacier Peak area are: northwesttrending foliation, compositional layering, and fold axes of metamorphic rocks; northwest-trending high-angle faults associated with the Chiwaukum graben; a northeast-trending local structure defined by the alignment of steep-walled satellitic dikes and stocks west of the White Church River; and the westward projection of the Sitkum stock (Tabor and Crowder, 1969).

..Geophysical Summary: No detailed geophysical survey of the Glacier Peak area has been undertaken to date.

..Geologic Hazards: Renewed volcanic activity on Glacier Peak would be expected to result in property damage and possible loss of life. Though the latest dated volcanic events are dated at ca. 12,000 years B.P., the volcano cannot be considered to be extinct. Although lava flows, which are generally considered to be a minor hazard, have been the dominant form of activity, eruptions of pyroclastic materials, nuee ardantes, and associated mudflows are found in the geologic record and comprise the latest known activity and are a much greater threat to property and life. (Tabor and Crowder, 1969) 
In addition to the hazards presented by potential volcanic activity, landslides and other slope stability problems are common in the study area. 


\section{RESERVOIR CHARACTERISTICS}

..Reservoir Temperature

. Surface: $21^{\circ}-38^{\circ} \mathrm{C}$ (Schuster et al., 1978; Renner and Lee, 1974)

. Subsurface: No information is available.

. .Geochemical

SiO2: $91^{\circ}-211^{\circ} \mathrm{C}$ (Schuster et al., 1978)

$\mathrm{Na}-\mathrm{K}-\mathrm{Ca}: 186^{\circ}-207^{\circ} \mathrm{C}$ (Schuster et al., 1978)

..Flow Rates: 1.90 1/s (Schuster et al., 1978)

..pH: 6.5-8.4 (Schuster et al., 1978)

..Total Dissolved Solids: Ca. 2,000 ppm (Schuster et ar., 1978)

..Fluid Chemistry:

Kennedy Hot Springs Gamma Hot Springs Sulphur Creek Hot Springs

$\mathrm{Cl}$

$\mathrm{Na}$

$\mathrm{K}$

$\mathrm{Ca}$

$\mathrm{SiO}_{2}$

(Schuster et az., 1978)

..Estimated Non-electric Energy Potential. (MBtuh 30 years): No estimate is possible at this time.

..Subsurface Area of Reservoir: No estimate is possible at this time. 
..Land Ownership

\begin{tabular}{|c|c|c|c|}
\hline $\begin{array}{l}\text { TOTAL AREA } \\
\text { (Acres) } \\
3,311\end{array}$ & $\begin{array}{l}\text { FEDERAL } \\
\text { (Acres) } \\
3,31.1\end{array}$ & $\begin{array}{l}\text { STATE } \\
\text { (Acres) }\end{array}$ & $\begin{array}{l}\text { PRIVATE } \\
\text { (Acres }\end{array}$ \\
\hline
\end{tabular}

..Land Leased

None

None

.. Highest Priced

Leases (Dollars/

Acre)

$\underset{N / A}{\$}$ N/Acre Lessee

.. Tentative Lease Sale Dates:

No lease sale date has been set and none is expected as long as the area is within the Glacier Peak Wilderness Area (Taylor, personal communication. 1978).

... Number of Sales

Offered But No Bids:N/A

N/A

.. Number of Bids Rejected (Resulting in No Lease): N/A

..Surmary of Leasing Status and Needs: No leasing has taken place in the Kennedy Hot Springs KGRA and no lease applications will be accepted by BLM as long as the area remains within the Glacier Peak Wilderness Area.

Nondestructive types of prospecting are permitted within a wilderness area (Taylor, personal communication, 1978). 
..Present Development Status: There has been no geothermal development to date. Kennedy Hot Springs is a recreational area in the Glacier Peak Wilderness Area and the springs are used for bathing by visitors to the area.

The leasing of lands within a wilderness area for geothermal development is excluded by provisions of the Geothermal Steam Act of 1970 (Appendix I).

.Projected or Planned Development: There is no known projected or planned development in the area. Interest in the area is expected to remain low until such time as land status questions are resolved and/or sites of interest are located outside the boundaries of the wilderness area. 


\section{INSTITUTIONAL CHARACTERISTICS}

..Institutional Requirements: No lease applications will be accepted or leases granted for areas within the Glacier Peak Wilderness Area (Geothermal Steam Act of 1970)(Appendix I).

In areas adjacent to the KGRA which lie outside the wilderness area an environmental statement would have to be prepared and accepted before leasing could begin.

..Agency and Public Attitudes: Strong opposition to leasing and development would be expected due to the wilderness status of the KGRA.

Environmental and aesthetic values are high as is the recreational value of the area.

..Status of Requirements (i.e., EIA/EIS Requirements): At present there are no expected changes in the wilderness status of the KGRA and no environmental study is being planned by the forest service or any other agency. 
.. Climate

.Prevailing Winds: The prevailing winds are from the southeast to southwest (Phillips, 1966).

.Precipitation (Annual): The mean annual precipitation is 2,032 mm (80 inches) at Darrington (Phillips, 1966).

..Days of Sunshine (Annual): Information is not available.

..Average Temperature: The average annual temperature at Darrington is $15.40^{\circ} \mathrm{C}\left(59.8^{\circ} \mathrm{F}\right)$ (Phillips, 1966).

Minimum: The average minimum temperature at Darrington is $3.72^{\circ} \mathrm{C}\left(38.7^{\circ} \mathrm{F}\right)$ (Phillips, 1966).

Maximum: The average maximum temperature at Darrington is $9.60^{\circ} \mathrm{C}\left(49.3^{\circ} \mathrm{F}\right)$. (Phillips, 1966).

..Degree Days (Annual): The average for the potential service area is 6,163 on a base of $18.3^{\circ} \mathrm{C}\left(65^{\circ} \mathrm{F}\right)$ (Phillips, 1966).

- Relative Humidity (Seasonal Peaks):

Summer: $4^{\circ 0} 89$ percent $16^{\circ 0} 57$ percent

Winter: $4^{\circ 0} 77$ percent $16^{\circ 0} 73$ percent

(Phillips, 1966)

..Air Quality: The main pollutants are dust and smoke. Air quality is high except during periods of slash burning or at time of forest fires.

..Geologic Factors: Geologic hazards are mainly in the form of slope stability problems and renewed volcanic activity (Tabor and Crowder, 1969).

.. Water Quality: Water quality is very high. Streams in the area are rated as Class AA (extraordinary). All streams are in the Mount BakerSnoqualmie National Forest, and all are under federal ownership. The average streamflow of the combined streams in the area is approximately $849,0001 / \mathrm{s}$ (Washington Administrative Code [WAC] Chapter 173-201 WAC; Landes, 1917; James, personal communication, 1978).

..Noise: Ambient noise levels are low.

..Biological

..Dominant Flora: The KGRA contains species common to the Canadian and Hudsonian Life Zones.

The Canadian species include: Douglas fir Pseudotsuga taxifolia, western hemlock Tsuga heterophy ZZa, amabaslis fir Abies comabalis, white pine Pinus monticola, and noble fir Abies nobilis. Common shrubs include: Vaccinnium ovalifolium, Vaccinnium membranaceum, Menziesia fermiginea, Alnus sinuata, Acer circinatum, Sorbus 
cascadensis, Cormus canadensis, Clintonia uniflora, Stenauthium occidentale, Galium oreganum, and Prenanthes lessingii. Saprophytes are abundant in the Canadian Zone.

The Hudsonian species include: alpine fir Abies Zasiocarpa, Alaska cedar Chamaecyparis nootkatensis, and white-barked pine Pinus albicaulis. The most common shrubs in the Hudsonian zone are: Salix barclayi, Salix commutata, Juniperus sibirica, Alnus sinuata, Ribes howellii, Lutkea pectinata, Potentilla fruticosa, Sorbus occidentalis, Spiraea densiflora, Pachistima myrsinites, Arctostaphylos nevadensis, Arctostaphylos uva-ursi, Cassiope mertensiana, Cassiope stelleriana, Phyllodoce empretriformis Rhodedendron albiflorum, and Gaultheria ovalifolia (U.S. Army Corps of Engineers, 1973).

..Dominant Fauna: Dominant species include: black bear, black tailed deer, cougar, snowshoe hare, beaver, raccoon, mink, ermine and river otter (U.S. Army Corps of Engineers, 1973).

... Endangered, Rare, Remnant, Unique or Otherwise Significant Species:

..Flora: Climax communities: Douglas fir Pseudotsuga taxifolia and grand fir Abies grandis stands (U.S. Army Corps of Engineers, 1973; Kl ine, 1977).

..Fauna: Species include: cinereous shrew Sorex cinereus cinereus, fisher Martes pennanti, red fox Vulpes fulva cascadensis, wolf Canis lupus fuscus, wolverine Gulo luscus luteus and Canada lynx Lynx canadensis. Bald eagles have been sighted in the area, but it has not been established that any nesting areas are present in the KGRA (U.S. Army Corps of Engineers, 1973; Kl ine, 1977). 
..Utility or Energy Transmission Corridors and Facilities:

One $115 \mathrm{KV}$ line ca. $64 \mathrm{~km}$ (40 miles) north--owned by Puget Sound Power and Light Co.

One $345 \mathrm{KV}$ line ca. $64 \mathrm{~km}$ (40 miles) north-owned by BPA.

Two $230 \mathrm{kV}$ lines ca. $64 \mathrm{~km}$ (40 miles) north--owned by BPA.

(BPA Area Office Map, Sheet 6, 1975)

. Transportation Corridors or Facilities: Main transportation routes include state route 530 to Darrington and forest service a11 weather routes 211 and 314 to the Glacier Peak Wilderness Area. (U.S. Forest Service, Mount Baker-Snoqualmie National Forest Map, 1978) 
..General Description of Population: The population of the area which would be the potential service area is low and widely scattered. No population center is within the KGRA and the closest population center is Darrington ca. $45 \mathrm{~km}$ away. Darrington has a 1977 population of 1,031 which was a 5.8 percent decrease since 1970.

Employment is primarily in the timber products industry and includes both timber harvesting and the manufacture of timber products (Washington Office of Finanacial Management, 1977).

..Economics

..Present Land Use: Land use in the KGRA is restricted to recreational and scientific activities through its wilderness status. Outside the Glacier Peak Wilderness Area, timber production is the primary land use and the timber products industry forms the economic base of the area.

..Future Land Use: No significant change in land use patterns or the economic base of the area is expected. 
MOUNT BAKER P.GRA 
FIGURE 9 - GEOTHERMAL LAND CLASSIFICATION MAP

MOUNT BAKER PGRA

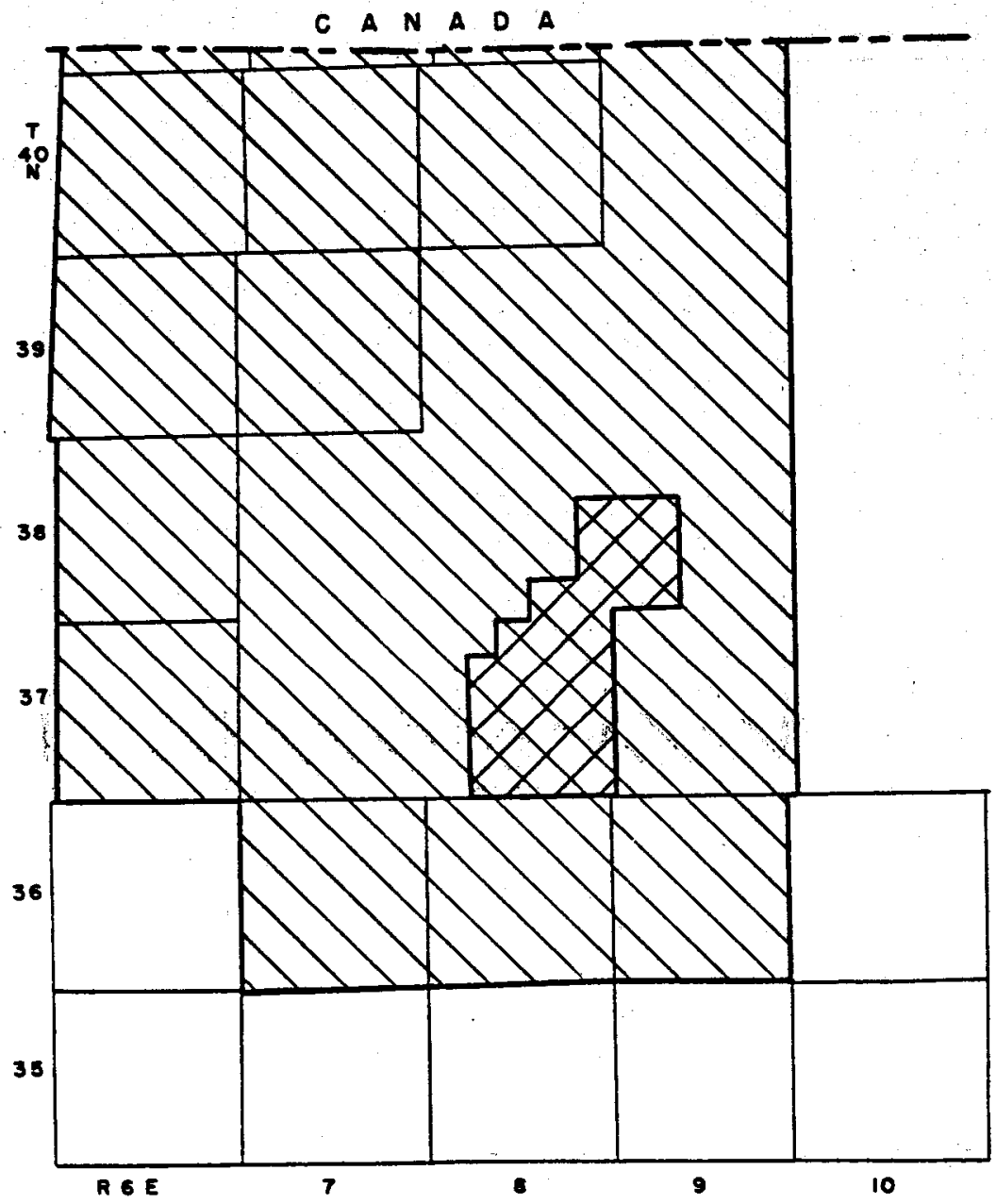

LEGEND

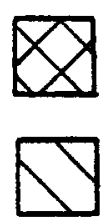

AREA WITH LEASE APPLICATIONS

LANDS VALUABLE PROSPECTIVELY FOR

GEOTHERMAL RESOURCES
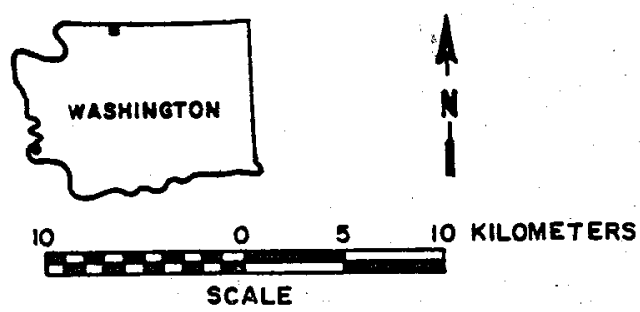

Base map: U.S. Geological Survey Geothermal Land Clossification Mop, Washington, 1974 


\section{MOUNT BAKER PGRA}

\section{Introduction}

The Mount Baker PGRA lies in the northern Cascades in the northern most part of the state and encompasses some 449,280 acres. The majority of the acreage lies in the Mount Baker National Forest. Of the total acreage, ca. 11,500 acres falls within the North Cascades National Park and ca. 57,600 acres is in the Mount Baker Recreation area. The study area is located in Whatcom County and is ca. $65 \mathrm{~km}$ (40 miles) east of Bellingham, Washington.

The area has been designated as a PGRA (Potential Geothermal Resource Area) by the U.S. Geological Survey and is considered to be one of the top four geothermal prospects in the State of Washington.

The rectilinear location of Baker Hot Springs is SW7/4 sec. 20, T. 38 N., R. $9 \mathrm{E}$. This is the only hot spring in the study area, and it is the area around the hot springs that has received the most attention as far as the filing of lease applications with the BLM regional office in Portland, Oregon, is concerned.

The entire study area is sparsely populated the the towns of Glacier and Mount Baker are the only population centers within the study area. Major population centers and industrial sites are $60+\mathrm{km}$ from the PGRA. The distance which any resource will have to be transported will be a major factor in the economics of developing geothermal resources in this area.

Land use in the study area is primarily devoted to recreation and timber production. Outside to the west, agriculture and agricultural related activities dominate land use patterns. Topographically, the study area is one of considerable relief and elevations reach $3,285 \mathrm{~m}(10,778 \mathrm{ft}$.$) ,$

Energy consumption in the areas surrounding the PGRA is primarily for space heating and manufacturing. Lesser amounts of energy are used in timber harvesting, agriculture and agricultural processing. Industrial consumption is primarily for the processing of timber products, petroleum refining and in the aluminum industry. Six of the top twenty energy consumers in the state are located within the potential service area. The total energy demand of these six companies is 48,002 ( $10^{9}$ BTU/yr.). Present energy needs are met by a combination of oil, natural gas, and electricity.

The recoverable energy potential of the Mount Baker PGRA is impossible to estimate from the limited geological and geophysical data that is presently available. The study area has received and continues to receive considerable attention due to the highly increased thermal activity which has occurred near the summit of Mount Baker since 1975. This increased activity consists of the melting of considerable amounts of snow and ice and the venting of large amounts of steam from fumeroles. It has been estimated that the total heat flux that would account for 
the present observed snow and ice loss on Mount Baker is ca. 30 megawatts at 180 watts per square meter. Estimates of the reservoir temperature at Baker Hot Springs from geothermometry range from $132^{\circ}$ to $175^{\circ} \mathrm{C}$.

The estimated reservoir temperature could provide a resource that could be utilized for electrical generation through a binary system or for the preheating of industrial water at the higher temperatures (above ca. $150^{\circ} \mathrm{C}$ ), and for space heating, processing of agricultural products, greenhouses, and lumber drying at the lower temperatures.

Geothermal water has proved to be economically competitive with other energy sources at Boise, Idaho; Klamath Falls, Oregon; and Wairakei, New Zealand, for all of the above suggested uses except electrical generation using a binary system. The utilization of binary systems for electrical generation and the economics of such systems are presently the subject of a pilot project at Raft River, Idaho. The eventual utilization of hydrothermal resources in and around the Mount Baker PGRA wil1 be dependent upon the quality and quantity of the resouce found and the cost of transportation to potential users. The city of Bellingham is presently looking at the potential of obtaining geothermal energy for space heating.

Lease applications for 24,000+ acres of forest service land have been filed with the BLM. These lease applications have not been acted upon and leasing cannot begin until after the surface management agency--the Mount Baker Forest Service--prepares and has accepted an environmental statement concerning geothermal exploration and development. Leasing of land in the North. Cascades National Park is not permitted under provisions of the Geothermal Steam Act of 1970 (Appendix I). Land in the Mount Baker Recreational Area, although reserved primarily for recreational activities by the Secretary of Agriculture, may be utilized for other purposes after clearance by the Department of Agriculture. It is at present unclear what procedures would have to be followed in order to obtain leases and exploration and development permits on land in the Mount Baker Recreation Area. It is possible that each request will have to be considered separately by the Department of Agriculture.

The preparation of an environmental statement in regard to geothermal exploration and development on a portion of land upon which lease applications are on file was to have begun in August 1978; however, due to a lack of personnnel the preparation of such a statement has been postponed. It is at present unclear when such a study will be undertaken. When funds and personnel are made available to the forest service, the preparation and acceptance of an environmental statement is expected to take from 1 to 3 years. This time could be cut to a minimum if the Timber Management Plan now in preparation can be used extensively for baseline data.

The acceptance of an environmental statement is expected, at present, by late 1979 or early 1980. An additional 2 to 3 years will be required for geological and geophysical assessment and it will not be until the mid 1980's that developemnt plans for the area can be finalized. Power on line could be realized by the late 1980's. 
SITE DATA SUMMARY

SITE: Mount Baker PGRA

..Physical Reservoir Data

. Temperature ${ }^{\circ} \mathrm{C}$

Surface: $38^{\circ}-42^{\circ} \mathrm{C}$ (Schuster et al., 1978)

Subsurface: $146^{\circ}-175^{\circ} \mathrm{C}$ (estimated from Na-K-Ca)(Schuster et àl., 1978)

..Total Dissolved Solids (PPM): ca. 500 ppm (Schuster et al., 1978)

..Estimated Non-Electric Energy Potential (MBtuh* 30 years): 85 MBtuh (Williams, et al. 1977)

..Type of Overlying Rock: Granite overlain by Tertiary basalt. (Huntting, et al., 1961)

..Estimated Depth to Top of Reservoir (meters): No estimate is possible at present.

..Site Land Status

$\begin{array}{llll} & \text { FED } & \text { STATE } & \begin{array}{l}\text { PRIVATE } \\ 1,920\end{array} \\ \text { Total Acres } & 435,740 & & \\ \text { Total Acres Leased } & \text { None } & & \text { None }\end{array}$

(Renner and Lee, 1974; U.S. Forest Service Mount Baker-Snoqualmie National Forest Map, 1978)

..Geothermal Development Status: The USGS began monitoring thermal activity at Baker Hot Springs in 1975. The Washington State Department of Natural Resources was engaged in the geochemical analyses of waters from Baker Hot Springs in 1973. At present scientists from Western Washington University and the University of Washington are monitoring activity on Mount Baker due to renewed thermal activity which began in 1975. Analyses of gases vented from the volcano as well as seismic studies are among the ongoing projects. (Schuster, personal communication, 1978)

..Local and State Attitude Toward Geothermal Development: There is a high degree of interest in the area by the Washington Division of Geology and Earth Resources, the Washington Energy Office, the U.S. Geological Survey, and the city of Bellingham.

The forest service is very concerned about possible environmental impacts from exploration and development. (Taylor, in preparation)

..Land Use and Population: The principal land uses are recreation and timber production. A major portion of the PGRA is in the Mount Baker Recreation Area and a smal1 portion is in the North Cascades National Park. Recreation is the principal activity in those two areas. The study area has a low population density and there are no major population centers in the PGRA. (Taylor, in preparation; Washington Office of Financial Management, 1977) 
..Comments and Critical Issues: At present the forest service is planning to produce an environmental statement in relation to the geothermal leasing in the Baker Hot Springs area. The study is designed to cover on 1 y 6,100 acres although almost four times that amount was covered by lease applications at one time. If the study area is not increased, unfortunate delays in the leasing of additional areas will take place. Environmental concerns will be critical to the eventual development of any geothermal resources in the area. Also of critical importance to eventual non-electric development is the distance to population centers. (Taylor, personal communication, 1978) 
.. Latitude: $48^{\circ} 46^{\prime} \mathrm{N}$.

. Longitude: $112^{\circ} 40^{\prime} \mathrm{W}$.

..Rectilinear: SWT/4 sec. 20, T. $38 \mathrm{~N} ., \mathrm{R} .9 \mathrm{E}$.

(Renner and Lee, 1974;-U.S. Forest Service Mount Baker-Snoqulamie National Forest Map, 1978)

..County: Whatcom

..Adjacent Counties: Skagit, Okanogan, and to the north is Canada (Washington Highway Commission Map, 1975).

..Topography: The study area is in the high Cascades and elevations range from $150 \mathrm{~km}(492 \mathrm{ft}$.$) to 3,285 \mathrm{~m}(10,778 \mathrm{ft}$. $)$. Much of the area is covered by steep ridges and deep canyons. Numerous glaciers are found on Mount Baker. (Lake Shannon quadrangle, 15-minute series, 1952; Mount Shusksan quadrangle, 15-minute series, 1953)

..Present Land Use: The primary land uses are recreation and timber production. Land in the Mount Baker Recreation Area is set aside for recreational uses by the Secretary of Agriculture, although other activities such as timber harvesting may take place at the discretion of the Secretary. Land use in the North Cascades National Park is restricted to recreational and educational uses. (Taylor, personal communication, 1978; Tayor, in preparation)

. Future Land Use Plans: The area is expected to retain its high recreational use due to the Mount Baker Recreation Area, Baker Lake, and the North Cascade National Park. Some timber harvesting is expected to continue. (U.S. Forest Service Mount Baker-Snoqualmie National Forest Maps, 1978; Taylor, personal communication, 1978)

...Aesthetics: The Mount Baker PGRA is an area of extremely high aesthetic value. To a majority of the visitors to the area the aesthetic experience is paramount and the principal reason behind nearly a quarter of the visits to the area (Taylor, in preparation).

..Historica/Archaeological Significance: There are no known, historical or archaelogical sites in the PGRA, but to the south is an area of shell mounds which are suspected to be Indian in origin. No thorough study of the archaeology of the area has been undertaken (U.S. Forest Service Mount Baker-Snoqulamie National Forest Map, 1978; Odegaard, 1976). 
..Geologic Description: Mount Baker with an elevation of $327 \mathrm{~m}(10,750$ ft.) sits upon a basement of Paleozoic to lower Tertiary sedimentary and metamorphic rock. The Paleozoic section consists of two principal groups - greenstone and associated sedimentary rocks, and carbonaceous phyllites. Sedimentary rocks of what is believed to be Mesozoic age range from fine, thinly laminated shales to coarse conglomerates. Intermediate-size clastics predominate. The lower Tertiary is represented by a thick series of shales and arkosic sandstones containing thin coal seams. A granodiorite batholith of undetermined age intrudes some of these rocks.

Although the rocks underlying Mount Baker are much older than those below Mount Rainier and Mount St. Helens, the erosional history of the two areas is believed to have been similar during the latter part of the Tertiary, and it can be concluded that the early lavas were poured out onto a topography as rugged as at present (Coombs, 1939).

The volcanic rocks associated with Mount Baker may be divided into three groups, from youngest to oldest: Mount Baker, the Black Buttes, and scattered flow remnants and subsidiary vents.

Mount Baker is an andesitic cone which has been relatively little dissected by erosion. The base of the volcano which averages $1,500+\mathrm{m}$ (ca. 5,000 ft.) in elevation is capped by a ca. $1.6 \mathrm{~km}(5,249 \mathrm{ft}$.) high cone.

Most of the material that issued from the central vent was in the form of flows. These flows are composed exclusively of andesite, and of this amount 90 percent is pyroxene andesite. Little or no differentiation of the lava is seen and in this respect Mount Baker is very similar to Mount Rainier.

The flows range in thickness from 5 to 15 meters (ca. 15 to $50 \mathrm{ft}$.). Some of the flows were quite fluid in comparison to those of the other large volcanoes in Washington. The largest flow, and one of the latest, follows the course of Sulphur Creek for $19 \mathrm{~km}$ (12 miles) to its confluence with the Baker River.

Pyroclastic rocks constitute probably less than 5 percent of the total volume of Mount Baker in sharp contrast to the volcanoes to the south, which include abundant pyroclastic material. Tuff and pumice occur. sporadically, but dark crystal ash is the most abundant pyroclastic material.

The summit consists of two peaks that were once part of a continuous rim. These two peaks are now separated by a deep crater. The Black Buttes, with a summit of ca. 2,450 meters (ca. 8,000 ft.), are located approximately $3.2 \mathrm{~km}$ ( 2 miles) to the east of the main summit, and probably have a much earlier beginning than Mount Baker. The degree of erosion of the Black Buttes as compared to Mount Baker suggests an 
older age and an age older than most of the other Cascade volcanoes except Mount Thielsen in Oregon.

Small remnants of flows to the north of Mount Baker present evidence of both early and late volcanic activity. Flows identifiable as either preglacial or interglacial in age are found near flows which are definitely postglacial (Coombs, 1939).

Volcanic activity has continued and probable volcanic events during the period 1800 to 1875 are dated by Folsom (1970) at 1843, 1854, 1858, 1859 , and 1870.

Activity consisting of the venting of large amounts of steam has been occurring since 1974.

..Geophysical Summary: The collection of geophysical data concerning Mount Baker was initiated for the purpose of monitoring the volcanic activity in regard to the predicting of future eruptions. The study involved seismicity, gravity, and tilt.

A seismometer was installed near Mount Baker by the U.S. Geological Survey in the summer of 1972 and is currently operated by the Geophysics Program of the University of Washington. The seismic coverage of the mountain was increased in 1975. Data obtained from the seismic net has shown an almost complete lack of earthquakes local to the volcano. The only definitely identifiable earthquake to occur since coverage began in 1972 was recorded in 1976. The earthquake was ca. $1 \mathrm{~km}$ east-southeast of Sherman Crater at a depth of $3-6 \mathrm{~km}$.

Gravity measurements have been made since May 1, 1975, by use of a 3 point net. In late summer of 1975 seven additional gravity stations were established. Data has shown small decreases, but analysis of the data collected through 1976 has not allowed for the drawing of definite conclusions. Unfortunately more recent data has not been made available.

Tilt has been measured using both spirit-level tilt stations and borehole tiltmeters. Data collected have been inconclusive and in certain instances contradictory.

The limited information obtained from the above geophysical methods has proved to be nonconclusive, in most cases. It can be concluded that none of the techniques points to significant alterations in the mountain which would be expected before an eruption (Frank et al. 1977).

Infrared studies were also begun during 1975 and have continued through 1978. Thermographic images were obtained at 10-day intervals beginning in March 1975. Both day and night coverage has been obtained. Heat flow estimates, made from the infrared information, are as high as $30 \mathrm{MW}$ of heat released at an average flux density of $180 \mathrm{w} / \mathrm{m}^{2}$. Pre -1975 estimates have been 2 MW of heat at an average heat-flux density of about $10 \mathrm{w} / \mathrm{m}^{2}$. Four possible structural implications obtained from the thermal features observed have been suggested by Frank et al (1977):

"1. At the west and northwest rims much of the activity is confined to breccia that is interlayered with lava flow. As rising heat nears the ground surface, a preferred path of connective flow is evidently through the more permeable breccia. 
2. Fumarole clusters form a discontinuous semicircle of activity along the inside rim of Sherman crater, except where hydrothermal activity seems to be absent along the south rim. Such a pattern suggests that most of the the hydrothermal emmission is controlled by concentric fractures that might be associated with the initial formation on the crater. Surface displacements related to such structural features, however, have not been identified.

3. The location of some of the new activity suggests an east-west structural control across the center of Sherman Crater. For example, two long east-trending lobes of activity extend downslope from the west rim, and an east-west line of fumaroles occurs along the north shore of the lake and the north bank of the outlet stream.

4. The east breach apparentiy overlies the most direct permeable path from the volcanic heat source because this area has the hottest and largest fumaroles. Furthermore, heat activity has historically been concentrated in this area since at least 1900. The presence of the breach itself indicates that at some time in the past either local hydrothermal or volcanic activity or erosion facilitated by hydrothermal alteration removed a section of the crater rim."

The geophysical and infrared studies, though quite detailed for the upper portion of the mountain and in regard to the potential for an eruption, give little information about possible relationships between the present thermal manifestations and Baker Hot Spring or the potential for goethermal resources in the study area.

..Geologic Hazards: The increased thermal activity, which has been observed on Mount Baker over the past several years, has increased the potential of the occurrence of a major destructive event.

Since the mid $1800^{\prime} s$, there have been reports of several large mass movements of undetermined cause. These include a debris avalanche, which traveled $11 \mathrm{~km}$ beyond the Rainbow Glacier terminus about 1860, and a number of either debris avalanches, debris flows, or jokultilaups which swept $5 \mathrm{~km}$ below the Eastern Glacier in 1911, $9 \mathrm{~km}$ from the Deming Glacier in 1927, and repeatedly to unspecified distances down valley from the Mazama, Roosevelt, and Thunder Glaciers. Avalanches have occurred at fairly regular intervals since 1958 (Frank et al., 1975).

The most probable types of large mass movements that could occur as a result of the present thermal activity would be mudflows having speeds of as much as $50 \mathrm{~km}$ per hour that would originate from mixtures of snow, ice, and melt water and avalanches of structurally weak clay-rich rocks that make up the rim of Sherman Crater. At least eight massive mudflows have occurred over the past 10,000 years as seen in the geologic record. The largest known mudflow had an estimated volume of between 40 million and 50 million cubic meters, and extended at least $27 \mathrm{~km}$ down the valley of the Middle Fork of the Nooksack River (Frank et al. 1975).

A possible worst case event, however, might be a larger, air-cushioned avalanche of as much as 20 to 30 million cubic meters that could hit Baker Lake at speeds of more than $300 \mathrm{~km}$ per hour and generate a wave of water large enough to overtop Upper Baker Dam. At least 30 million 
cubic meters of potentially unstable material occurs as hydrothermally altered remnants of the rim of Sherman Crater and could provide the required volume for the estimated worst case event or for smaller avalanches and mudflows. An earthquake, steam explosion, or eruption could provide a suitable trigger to initiate movement (Frank et al. 1977).

There is also evidence of several lava flows and tephra eruption during the past 10,000 years. The latest of these eruptions could have taken place as late as the mid 1800's (Hyde and Crande11, 1975, 1977). Folsom (1970) dates probable volcanic events in 1843, 1854, 1858, 1859, and 1870 .

Seismic activity has been low and the area has not experienced major earthquake activity during the period 1840 to 1974 (Rasmussen, 1967; Crosson and Millard, 1974). Rasmussen (1967), however, does place the area within the zone of potential moderate damage from earthquake activity. 


\section{RESERVOIR CHARACTERISTICS}

.. Reservoir Temperature

. Surface: $38^{\circ}-42^{\circ} \mathrm{C}$ (Schuster et az. 1978)

. Subsurface: No subsurface information is available.

. Geochemical

$\mathrm{SiO}_{2}: 134^{\circ}-157^{\circ} \mathrm{C}$ (Schuster et al., 1978)

Na-K-Ca: $146^{\circ}-175^{\circ} \mathrm{C}$ (Schuster et az., 1978)

.Flow Rates: $0.43 \mathrm{l} / \mathrm{s}$ (Schuster et al., 1978)

$\therefore \mathrm{pH}: 7.7-8.4$ (Schuster et az., 1978)

. Total Dissolved Solids: ca. 500 ppm (Schuster et az., 1978)

..Fluid Chemistry:

Mount Baker Hot Springs

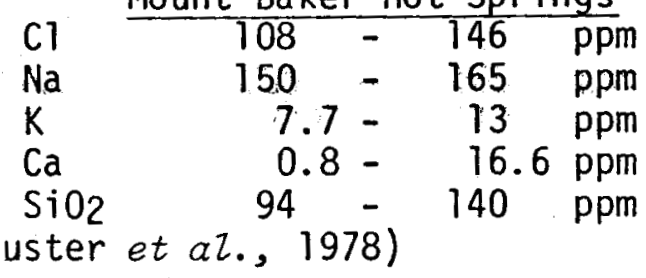

..Estimated Nonelectric Energy Potential (MBtuh 30 years): 85 MBtuh (Williams et al., 1977)

. Subsurface Area of Reservoir: No estimate is possible at this time. 
..Present Development Status: There has been no geothermal development to date. The USGS began monitoring thermal activity at Baker Hot Springs in 1975. The Washington State Department of Natural Resources was engaged in the geochemical analyses of waters from Baker Hot Springs in 1973 and again in 1978. At present scientists from Western Washington State University and the University of Washington are monitoring activity on Mount Baker due to renewed thermal activity in the form of steam venting which began in 1975. Analyses of gases vented from the volcano as well as seismic studies are among the ongoing research projects (Schuster, personal communication, 1978).

..Projected or Planned Development: There is no known projected or planned development in the area. Interest in the area is expected to remain low until an environmental statement is released and leasing can begin. 


\section{INSTITUTIONAL CHARACTERISTICS}

... Institutional Requirement: The Geothermal Steam Act of 1970 (Appendix I) excludes national park lands from leasing and development.

Forest service lands cannot be leased until after the preparation and acceptance of an environmental statement concerning geothermal exploration and development.

Procedures for the leasing of lands in the Mount Baker Recreational Area have not been developed.

The question of ownership of geothermal resources on private lands is at present under consideration.

..Agency and Public Attitudes: Forest service opposition to leasing and development is expected to be strong due to the recreational and aesthetic value of the area. Dangers from potential mud slides caused by volcanic activity on Mount Baker could also have an effect on the forest service's final decision to lease lands in the area.

Environmental statements for geothermal leasing and development have been receiving. low priority and the environmental statement which was to have been begun in August 1978 has been postponed and no new date has been set.

The Washington Division of Geology and Earth Resources and the Washington Energy Office are at present very interested in developing plans for the geologic assessment and eventual development of geothermal resources in the Mount Baker PGRA.

The city of Bellingham is presently looking into the feasibility of obtaining hydrothermal fluids for space heating and industrial uses.

..Status of Requirements i.e., EIA/EIS Requirements: No plans are now under consideration concerning the preparation of an environmental statement for geothermal leasing on the federal lands concerned. 
ENVIRONMENTAL FACTORS

- Climate

.Prevajling Winds: Winds are from the southeast to southwest. (Phillips, 1966)

. Precipitation (Annual): Mean annual precipitation at Mount Baker Lodge is $3,348.2 \mathrm{~mm}$ (109.85 inches). Highest precipitation is from October to March with a mean of $386.2 \mathrm{~mm}$ (12.67 inches) per month (Phillips, 1966).

..Days of Sunshine (Annual): No information is availabie.

..Average Temperature: Mean annual temperature is $4.5^{\circ} \mathrm{C}\left(40.1^{\circ} \mathrm{F}\right)$ at Mount Baker Lodge (Phillips, 1966).

Minimum: Mean minimum temperature is $0.5^{\circ} \mathrm{C}\left(32.9^{\circ} \mathrm{F}\right)$ at Mount Baker Lodge (Phillips, 1966).

Maximum: Mean maximum temperature is $8.5^{\circ} \mathrm{C}\left(47.3^{\circ} \mathrm{F}\right)$ at Mount Baker Lodge (Phillips, 1966).

.. Degree Days (Annual): The average for the potential service area is 6,334 on a $18.3^{\circ} \mathrm{C}\left(65^{\circ} \mathrm{F}\right)$ base (Phillips, 1966).

..Relative Humidity (Seasonal Peaks)

Summer: $\quad 4^{\circ 0} 89$ percent $16^{\circ 0} 57$ percent

Winter: $4^{00} 77$ percent $16^{\circ 0} 73$ percent

(Phillips, 1966)

..Air Quality: The main pollutants are dust and smoke. Air quality is high except during periods of slash burning or in time of forest fires. (Taylor, in preparation)

.Geologic Factors: The main geologic factors of environmental interest are slope stability problems and events which would be expected to accompany renewed volcanic activity. The greatest hazard to 1 ife and property would come from mudflows or an air-cushioned avalanche. (Frank et al., 1977)

..Water Quality: The water quality is very high. Streams in the area are rated as Class AA (extraordinary). All streams are in the Mount Baker-Snoqualmie National Forest and the North Cascades National Park and $a 11$ are under federal ownership. The average stream flow of the combined streams in the area is approximately 481,000 to $566,000 \mathrm{l} / \mathrm{s}$. Minimum flows should be $113,000 \mathrm{l} / \mathrm{s}$. (Washington Administrative Code [WAC] Chapter 173-201 WAC; Landes, 1917; and James, personal communication, 1978)

.. Noise: Ambient noise levels are low.

. Biologicar

..Dominant Flora: At the higher elevations Arctic-Alpine vegetation predominates. The surrounding area is dominated by species of the Canadian and Hudsonian Life Zones. 
The Arctic-Alpine species include: Juniperus sibirica, Salix cascadensis, Salix nivalis, Gaultheria humifusa, Empetrum nigrum, and the heathers Phyllodoce glanduliflora, Cassiope mertensiana, and Cassiope stelleriana.

The Hudsonian Species include: alpine fir Abies Lasiocarpa, mountain hemlock Tsuga mertensiana, Alaska cedar Chamaecyparis nootkatensis, and white-barked pine Pinus albicaulis. Common shrubs in the Hudsonian Life Zone are Salix barclayi, Salix commutata, Juniperus sibirica, Alnus sinuata, Ribes howellii, Lutkea pectinata, Potentilla fruticosa, Sorbus occidentalis, Spiraea densiflora, Pachistima myrsinites, Arctostaphylos nevadensis, Arctostaphylos uva-ursi, Cassiope mertensiana, Cassiope stelleriana, Phyllodoce empetriformis, Rhododendron albiflorm, and Gaultheria ovalifolia.

The Canadian species include: Douglas fir Pseudotsuga taxifolia, western hemlock Tsuga heterophy Zla, amabaslis fir Abies amabaitis, white pine Pinus montecola, and noble fir Abies nobilis. Also found in the Canadian Life Zone are Vaccinnizm ovalifolium, Vaccinnium membranaceum, Menziesia fermiginea, Alnus sinuata, Acer circinatum, Sorbus cascadensis, Cornus canadensis, Clintonia uniflora, Stenauthium occidentale, Galizm oreganum, and Prenanthes lessingii. Saprophytes are abundant in this zone (U.S. Army Corps of Engineers, 1973).

..Dominant Fauna: The dominant fauna species include: black bear, black tailed deer, snowshoe hare, beaver, raccoon, mink, ermine, river otter, cougar, and mountain goat.

.. Endangered, Rare, Remnant, Unique or Otherwise Significant Species:

Flora: Tree specimens-deciduous: Douglas maple Acer glabrum var. douglasii.

Virgin Stand-North Fork Nooksack Research Natural Area and State Mountain. Habitat of important native plants - Nooksack Falls (Kline, 1977; U.S. Army Corps of Engineers, 1973)

Fauna: American peregrine falcon Falco peregrinus anatum and grizzly bear Ursus horribillis (endangered). Cinereous shrew Sorex cinereus streatori, fisher Martes pennanti, red fox Vulpes fulva cascadensis, wolf Canis lupus fuscus, wolverine Gulo Zuscus luteus, Canada lynx Lynx canadensis, long-eared bat Corynorhinus rafinesquii townsendii, Keen myotis Myotis keenii keenii, and woodchuck Marmota monax petrensis. Baker Lake spawning beach is also important to the area. (Kline, 1977; U.S. Army Corps of Engineers, 1973) 
..Utility or Energy Transmission Corridors and Facilities:

One $115 \mathrm{KV}$ line ca. $10 \mathrm{~km}$ ( $6.2 \mathrm{miles})$ south - owned by Puget Sound Power and Light Co.

Four $23 \mathrm{KV}$ lines ca. $29 \mathrm{~km}$ (18 miles) northwest - owned by Seattle City Light.

(BPA Area Office Map, Sheet 8, 1974)

. Transportation Corridors or Facilities: The main transportation routes include state routes 542 and 20 , and forest service all weather routes 386, 394 and 385 (U.S. Forest Service Mount Baker-Snoqualmie National Forest Map, 1978). 
.General Description of Population: Population levels in the PGRA are low and major population and industrial centers such as Bellingham, Ferndale, Anacortes, Sedro Wooley, and Mount Vernon are at considerable distance from potential resource areas. The 1977 population of Bellingham was 43,110; Ferndale, 3,180; Anacortes, 8,200; Sedro Wooley, 5,260; and Mount Vernon, 11,021.

Employment in the potential service area is concentrated in manufacturing, retail trade, and service industries. The area is a major consumer of energy and six of the top energy-consuming industries in the state are in the potential service area; these include timber products, smelting, and petro-chemicals (Rocket Research Company, 1977; Washington Office of Financial Management, 1977).

...Economics

..Present Land Use: The principal land uses in the Mount Baker PGRA are recreation and timber production. To the west of the PGRA agriculture replaces timber production as the economic base.

.Future Land Use: Significant changes in land use patterns are not expected to occur. 
YAKIMA 


\section{FIGURE 10 - GEOTHERMAL LAND CLASSIFICATION MAP YAKIMA}

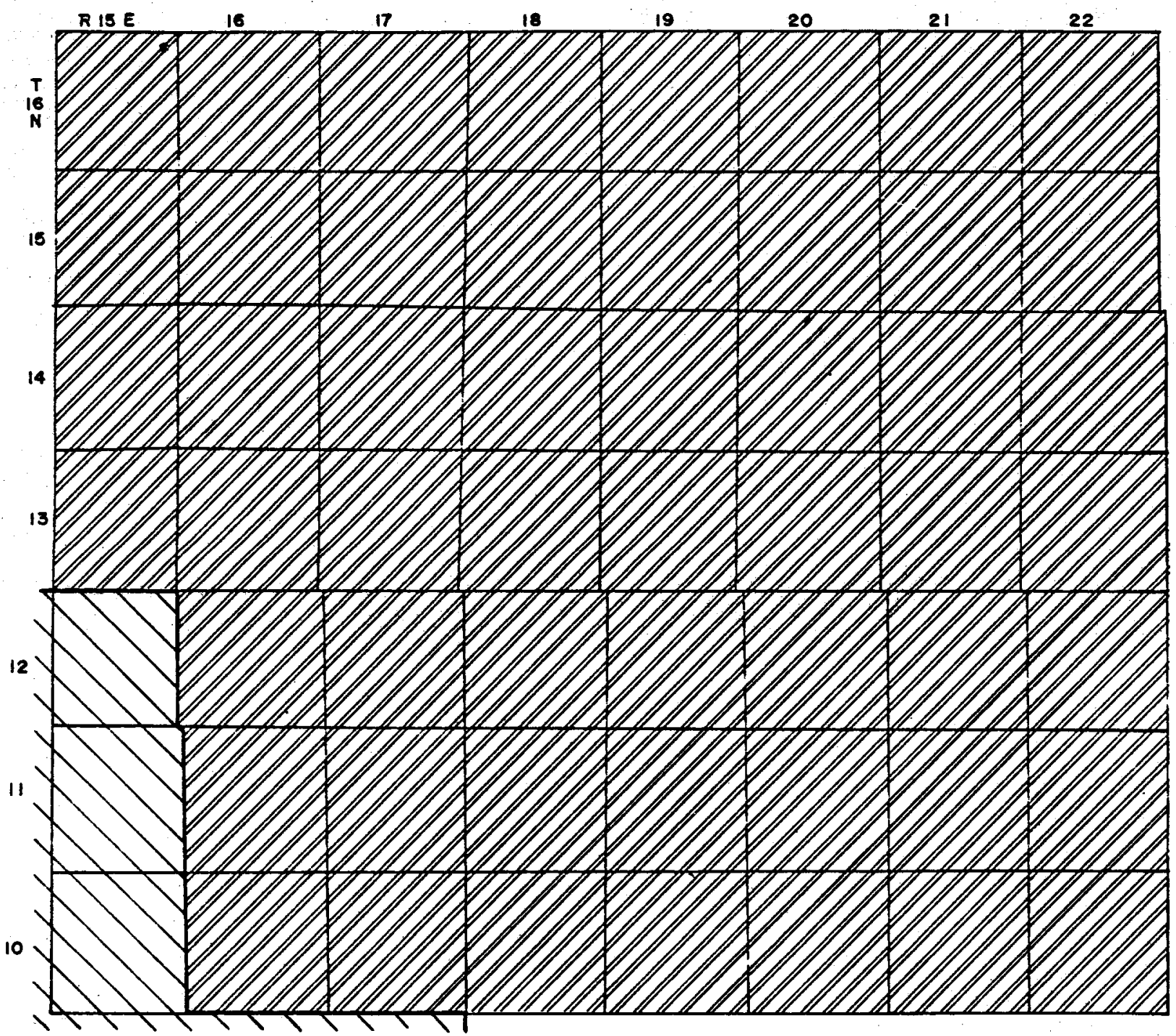

\section{LEGEND}

D LaINDS Valuable PRospectively for GEOTHERMAL RESOURCES

AREA OF KNOWN WARM WATER USE

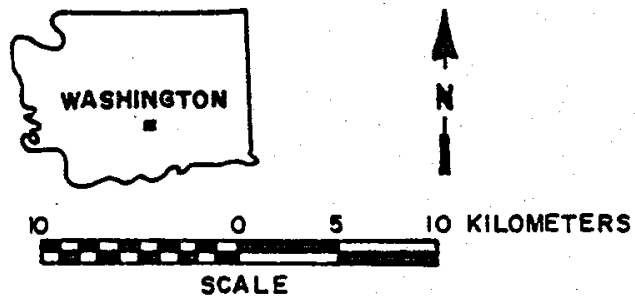

Bose map: U.S. Geological Survey Geothermal Land Classification Map, Woshington, 1974 


\section{YAKIMA}

\section{Introduction}

The area, which is being considered here, is in south-central Washington and centered about the city of Yakima. It includes a large portion of the Yakima Indian Reservation, the U.S. Military Reservation Yakima Firing Range, and extends into the Snoqualmie National Forest. The area also contains considerable amounts of state and private land.

The study area is not classified as either a KGRA (Known Geothermal Resource Area) or a PGRA (Potential Geothermal Resource Area) by the U.S. Geological Survey. However, the area is one of the top four prospects from the standpoint of state and local interest. This interest stems primarily from the presence of several warm water irrigation wells, thermal springs, and a thermal well (creamery well), which is presently supplying warm water to a car wash in Yakima.

Surface temperatures of the thermal springs is low, ca. $15^{\circ}$ to $17^{\circ} \mathrm{C}$, and below the range of potential utilization except for the case of agricultural irrigation. Estimated reservoir temperatures by geothermometry are in the range of $103^{\circ}$ to $114^{\circ} \mathrm{C}$ which, although low, could provide hydrothermal waters for agricultural drying, milk pasturization, space heating, greenhouses, fish farming, and agricultural irrigation.

The rectilinear location of Mool Mool Spring, Malotte Spring, and Mulford Spring is as follows: llool Mool Spring, SEl/4 sec. 20, T. 10 N., R. 16 E.; Malotte Spring, SET/4 sec. 32, T. 16 N., R. 17 E.; and Mulford Spring SWl/4 sec. 3, T. 14 N., R. 18 E. Thermal wells located in Yakima and Terrace Heights are also producing.

The study area contains several population centers clustered around Yakima, which is by far the largest city with a 1977. population of 51,100 . Throughout the remainder of the study area the population is widely scattered and the population density is low. Agricultural and agricultural-related activities predominate the land use of the area which is topographically one of little relief. Elevations range from ca. $340 \mathrm{~m}$ to $600 \mathrm{~m}$.

The present energy supply is provided primarily by natural gas and electricity.

The estimated reservoir temperatures would provide a resource adequate for space heating, greenhouse use, and agricultural product processing, including drying, aquaculture, and crop irrigation. Crop irrigation is presently taking place using hydrothermal waters in the Yakima area.

The economical use of geothermal resources of $\mathrm{ca} .100^{\circ} \mathrm{C}$ for the above activities has been proven at Klamath Falls, Oregon; Boise, Idaho; Reykjavik, Iceland, and in France and Hungary. However, in the Yakima area very little is known about the actual extent of the resource or the 
quality and quantity of the hydrothermal fluids that could be available. This lack of knowledge prevents a thorough assessment of the potential utilization of geothermal resources. There is also inadequate knowledge of the present use of the resouce as wells which presently supply warm water for irrigation were not drilled in search of hydrothermal water, but merely as water wells. It is not known for what reason the creamery well was drilled or its history of production. The we1l is presently being used by a car wash in Yakima to supply its warm-water needs, and thus must be considered to be the only application of the geothermal resource of the area.

The portions of the study area that fall within the Yakima Indian Reservation and the U.S. Military Reservation are closed to private exploration, leasing, and development through provisions of the Geothermal Steam Act of 1970. Exploration leasing and development in these areas is under the control of the Yakima Nation and the U.S. Army, respectively. State lands are managed by the Department of Natural Resources and federal lands are managed by the surface agency, which in the case of the Snoqualmie National Forest is the forest service.

Portions of the study area are under the jurisdiction of the Yakima Indian Nation and the U.S. Army, and leasing, exploration, and development in the respective areas will be dependent upon interest of these two entities in the use of potential resources. Areas within the Snoqualmie National Forest cannot be leased by BLM until such time as an environmental statement is prepared and accepted by the forest service. The situation on state and private lands is unclear as the State of Washington has failed to adopt legislation with respect to the ownership of the resource. In addition, no provision has been made by the state for the leasing of state land for geothermal exploration and development.

Leasing and exploration could begin in the Snoqualmie National Forest by the early 1980's if sufficient money is provided for the preparation of an environmental statement. Leasing of state land could likewise begin by 1980 if the 1.979 legislature addresses the problem and establishes statutes covering ownership, leasing, and development of the state's potential geothermal resources.

The issuing of leases would encourage exploration by private companies and assessment work could be completed within 2 to 3 years after leases are issued, thus allowing for the potential of power on line by the latter half of the $1980^{\prime} \mathrm{s}$.

Geothermal development on private lands can also be expected and would in most cases progress at a much faster pace than development on state and federal lands. 


\section{SITE DATA SUIMMARY}

SITE: Yakima

..Physical Reservoir Data

. Temperature ${ }^{\circ} \mathrm{C}$

Surface: $15-17^{\circ} \mathrm{C}$ (Schuster et al. 1978)

Subsurface: $\mathrm{Na}-\mathrm{K}-\mathrm{Ca} 51-64^{\circ} \mathrm{C}$

$\mathrm{SiO}_{2} 103-114^{\circ} \mathrm{C}$ (Schuster et al. 1978)

. Total Dissolved Solids (PPM): 88 - $126 \mathrm{ppm}$

..Estimated Non-Electric Energy Potential (MBtuh 30 years): No estimate is possible.

..Type of Overlying Rock: Volcanics (basalts) and some sediments (Robinson, 1966).

...Estimated Depth to Top of Reservoir (meters): No estimate is possible.

.. Site Land Status

$\begin{array}{lllll} & \text { FED. } & \text { STATE } & \text { PRIVATE } & \text { OTHER } \\ \text { Total Acres } & 276,480 & 161,280 & 599,040 & 253,440 \\ \text { Total Acres Leased } & \text { None } & \text { None } & \text { None } & \text { None }\end{array}$

. Geothermal Development Status: Some warm water is being used for irrigation purposes, and one well in Yakima is supplying warm water for a car wash.

..Local and State Attitude Toward Geothermal Development: There is a high degree of interest in the area by the Washington State Department of Natural Resources, and a geological assessment program is expected to be initiated in the area. There is also considerable interest in development of the resource by local farmers for irrigation and/or greenhouse use.

..Land Use and PopuTation: The area is open plains on the Yakima Basalt plateau of south-central Washington. Principal land use outside the city of Yakima is agriculture, with grains and fruit being dominant.

The city of Yakima has a population of 55,100 , while the county of Yakima has a population of 155,700 with a population density of 36.48 per square mile (Washington Office of Financial Management, 1977).

..Comments and Critical Issues: The area has not received significant attention in terms of its geothermal potential and there exists a real need for geological, geochemical, and geophysical assessment in the area.

There is also a need for legislative action in the state to resolve several issues dealing with ownership and leasing of any potential resources. 
SITE LOCATION AND PHYSICAL DESCRIPTION

..Latitude: $46^{\circ} 35^{\prime} \mathrm{iN}$

..Longitude: $120^{\circ} 30^{\prime} \mathrm{W}$

..Rectilinear: T. $13 \mathrm{~N} .$, R. $18 \mathrm{E}$.

(Yakima West quadrangle, 7.5 minute series, 1958)

..County: Yakima

..Adjacent Counties: Klickitat, Skamania, Lewis, Pierce, Kittitas, Grant and Benton (Hashington State Highway Commission Map, 1975).

..Topography: The elevation of the area ranges from approximately 335.3 $\mathrm{m}(1,100 \mathrm{ft}$.$) to above 600 \mathrm{~m}(2,000 \mathrm{ft}$.$) . The Yakima area is one of$ little relief with east-west trending ridges to the north and south. (Yakima East quadrangle, 7.5 minute series, 1953; Yakima West quadrangle 7.5 minute series, 1958)

..Present Land Use: The dominance of agricultural activities is expected to continue in the area.

..Aesthetics: Although the aesthetic value of the Yakima area can be rated somewhat lower than areas of the high Cascades, it still must be considered to possess considerable scenic value; this is especially true of some the geologic exposures. Because of the relative low relief of the area, any development would have the potential of being seen from a considerable distance.

.Historical/Archaelogical Significance: The Wenas Creek Archaeological Site is located at the junction of the Yakima River and Wenas Creek.

The following are protected because of their recognition by the National Historical Register or are being considered for inclusion in the register: Capitol Theatre, Carbonneau Mansion, Donald House, Fort Simcoe, St. Joseph's Mission, Kamiakins Gardens, Matton Cabin, and the W. P. Sawyer House and Orchard (Odegaard, 1976). 


\section{GEOLOGICAL/GEOPHYSICAL DESCRIPTION}

..Geologic Description: The Yakima basalts began upwelling probably in iate Miocene time and covered basement rocks about which very little is known, except from exposures at the periphery of the flows. Thickness of the Yakima Basalt reaches $600+$ meter $(2,000 \mathrm{ft}$.$) in the area and$ consists of a series of flows with no significant interval of time between the flows. During the closing phases of Yakima Basalt extrusion the surface was showered with glass shards from Pliocene volcanoes to the west. At about the same time cross-bedded and channeled volcanic detritus of hornblende andesite composition was deposited in the area by east-flowing streams. At about this time, diastrophism began and is believed to have continued to the present (Robinson, 1966).

..Geophysical Summary: The area is one of very low seismic activity with no major earthquakes recorded from 1840 to the present (Rasmussen, 1967).

No other detailed geophysical data is available for the area although heat-flow measurements are being made in the area presently.

..Geologic Hazards: Geologic hazards are limited to some slope stability problems, floods, and Rasmussen (1967) places the area into the zone of expected minor damage from earthquakes. 
. . Reservoir Temperature

..Surface: $15^{\circ}-17^{\circ} \mathrm{C}$ (Schuster et az. 1978)

..Subsurface: No information is available.

..Geochemical

$\mathrm{SiO}_{2}: 103^{\circ}-114^{\circ} \mathrm{C}$

$\mathrm{Na}-\mathrm{K}-\mathrm{Ca}: 51^{\circ}-64^{\circ} \mathrm{C}$

(Schuster et al. 1978)

..Flow Rates: No information is available.

..pH: $7.6-7.7$ (Schuster et al. 1978)

. Total Dissolved Solids: Minimum 88 - 126 ppm (Schuster et az. 1978)

..Fluid Chemistry:

Cl

$\mathrm{Na}$

$\mathrm{K}$

$\mathrm{Ca}$

$\mathrm{SiO}_{2}$

(Schuster et al., 1978)

$17 \mathrm{ppm}$

$4.3 \mathrm{ppm}$

$12 \mathrm{ppm}$

$53 \mathrm{ppm}$
Malotte Spring $\quad$ Mulford Spring

$\begin{array}{cc}9.1 & \mathrm{ppm} \\ 13 & \mathrm{ppm} \\ 5.8 & \mathrm{ppm} \\ 32 & \mathrm{ppm} \\ 66 & \mathrm{ppm}\end{array}$

..Estimated Nonelectric Energy Potential (MBtuh 30 years): No estimate is possible.

..Subsurface Area of Reservoir: No estimate is possible at this time. 
LAND OWNERSHIP AND LEASING

..Land Ownership

TOTAL AREA

(Acres)

$1,290,240$

FEDERAL

(Acres)

STATE

276,480

(Acres)

PRIVATE

OTHER

..Land Leased

None

None

161,280

(Acres)

(Acres)

chand Leased

None

None

599,040

253,440

..Highest Priced Leases (Dollars/Acre)

N/A

N/A

N/A

N/A

N/A

.. \$/Acre

Lessee

N/A

N/A

..Tentative Lease Sale Dates:

None

None

None

None

None

. Number of Sales Offered

But No Bids:

N/A

N/A

N/A

N/A

N/A

. Number of Bids Rejected

(Resulting in No Lease): N/A

..Summary of Leasing Status and Needs: The land ownership is divided among federal, state, private, and the Yakima Nation. No provision exists under Washington law for the leasing of state or private lands for geothermal development. The leasing of Indian lands must be through the tribal government. To date no leases have been let on federal lands and this will remain the situation until environmental statements are completed. 


\section{GEOTHERMAL DEVELOPMENT STATUS}

..Present Development Status: To date the only uses of geothermal waters have been in irrigation of agriculture lands and for warm-water needs at a car wash in Yakima.

.Projected or Planned Development: There is no planned development in the area beyond the above uses. In the event that a geological assessment program were to identify a resource in the area, several users could be identified. The dominance of agriculture in the area would provide markets for geothermal energy in greenhouses, grain drying, sugar processing, soil warming, and food processing. 


\section{INSTITUTIONAL CHARACTERISTICS}

.Institutional Requirements: The Geothermal Steam Act of 1970 (Appendix I) precludes the leasing of lands on military reservations. Requirements have not been established concerning exploration and/or development on Indian lands.

Environmental statements will have to be prepared before leasing can take place on any federal property.

The question of ownership of any geothermal resources on state and private lands is under consideration, as is the question of leasing of state lands.

..Agency and Public Attitudes: Environmental statements prepared by federal agencies have received low priority. The Washington Department of Natural Resources and the Washington Energy Office are at present very interested in developing plans for geologic assessment of geothermal resources.

..Status of Requirements (i.e., EIA/EIS Requirements): The United Indians Planners Association Council is at present looking into requirements on Indian lands.

No plans are now under consideration concerning the preparation of environmental statements on either state or federal lands.

At present the Washington Department of Natural Resources and the Washington Energy office are looking at institutional factors affecting geothermal exploration and development. It is hoped that it will be possible to have the questions of ownership and leasing settled within the next 2 years. 


\section{ENVIRONMENTAL FACTORS}

.Climate

..Prevailing Winds. Prevailing winds in winter are from the west. During the remainder of the year the prevailing winds are from the WNW. (Phillips, 1960).

..Precipitation (Annual): The mean annual precipitation is 199.6 $\mathrm{mm}$ (7.86 in.) (Phillips, 1960). Highest rainfall comes in December and January and is approximately $25.4 \mathrm{~mm}$ (1.0 in.) per month. Lowest rainfall comes in July and August when only 2.5 to $5.1 \mathrm{~mm}$ (0.1 to 0.2 ins.) fall (Phillips, 1960).

..Days of Sunshine (Annual): No information is available.

.Average Temperature: The average annual temperature is $9.89^{\circ} \mathrm{C}$ (49.8 $\left.{ }^{\circ} \mathrm{F}\right)$ (Phillips, 1960).

.Minimum: The average minimum temperature is $2.17^{\circ} \mathrm{C}\left(35.9^{\circ} \mathrm{F}\right)$ (Phillips, 1960).

Maximum: The average maximum temperature is $17.56^{\circ} \mathrm{C}\left(63.6^{\circ} \mathrm{F}\right)$ (Phillips, 1960).

..Degree Days (Annual): Yakima has 1,163 degree heating days on a base of $18.3^{\circ} \mathrm{C}\left(65^{\circ} \mathrm{F}\right)$ (Philitips, 1960).

..Relative Humidity (Seasonal Peaks):

summer: $04^{\circ \circ} 84$ percent $16^{\circ \circ} 71$ percent

winter: $04^{\circ 0} 69$ percent $\quad 1^{\circ 0} 25$ percent

(Phillips, 1960)

. Air quality: Air quality in this area is generally considered to be good to very good. Particulate matter which makes up the greatest amount of pollutants is well below standards.

.Geologic Factors: Some areas experience some slope stability problems. Flooding may take place in restricted areas at time of heavy runoff.

..Water Quality: Water quality is not as high as in the high Cascades or the 0lympics. D0 levels are high, water quality is above set environmental standards (Washington Administrative Code [WAC] Chapter 173201 WAC).

..Nojse: Ambient noise levels are low except in the cities where traffic noises predominate.

..Biological

..Dominant Flora: The area is divided between the Arid Grassland Transition and the Upper Sonoran life zones. 
The Arid Grassland Transition Sprecies include: bunchgrass Agropyron spicatum, which is the most important, but also inciudes primrose Denothera pallida, lupines Lupinus and Mertensia. In ravines and near water courses such shrubs as hawthorn Crataegus douglasii, serviceberry Amelanchier cusickii, Amelanchier utahensis, ăspen Populus tremuZoides, syringa Philadelphus lewissi, snowberry Symphoricarpos albus, choke-berry Prunus melanocarpa, and elderberry Sambucus caeruzae.

The Upper Sonoran species include; cottonwood Populus hastata and willow Salix which are the most common trees al though a few pines and junipers are found in places. Most typical of the zone are grasses and shrubs such as the bunchgrass Agropyron inerme, Agropyron spictation, fox tail Alopecurus aegualis, cheat grass Bromus tectorum, mustard Arabis sp., Brassica sp., sagebrush Artemisia rigida, Artemisia tridentata, rabbit brush Chrysothamus nauseosus, Chrysothamnus viscidiflorus and cactus opuntia polyacantha (U.S. Army Corps of Engineers, 1973):

..Dominant Fauna: Dominant species include: California myotis Myotis califormeus californicus, long-eared bat Corynorhinus rafinesquii intermedius, coyote, and blacktailed jackrabbit. Fowl include: valley quail, snipe, dove, Hungarian partridge, ruffed grouse, sage grouse, bobwhite quail, ring-necked pheasant (Chinese), and chukar partridge (U.S. Army Corps of Engineers, 1973).

..Endangered, Rare, Remnant, Unique or Otherwise Significant Species:

..Flora: Moxee Bog Natural Landmark (U.S. Army Corps of Engineers, 1973).

..Fauna: American peregrine falcon Falco peregrinus anatum (endangered), sage grouse (critical), and long-eared bat corynorhinus rafinesquii intermedius.

The area also includes critical elk winter range and areas of general importance to elk.

Also of importance are: Naches Fish Hatchery, Yakima Fish Hatchery, and the Nelson Bridge Raceways.

There are also areas of significant waterfowl habitat (U.S. Army Corps of Engineers, 1973; Kline, 1977). 
..Utility or Energy Transmission Corridors and Facilities: Electric Transmission Lines: Yakima has several major electric transmission lines passing through. These include five operated by Pacific Power and Light, and two operated by BPA. Four of the PP\&L lines are to the south of Yakima and have capacities of 115, 230, 115 and $69 \mathrm{KV}$. The above four are within $6.4 \mathrm{~km}$ of Yakima. The fifth PP\&L line is a $230 \mathrm{KV}$ line $1.6 \mathrm{~km}$ north of town. The BPA lines are $115 \mathrm{kV}$. One is located $48 \mathrm{~km}$ east of town and one is $3.2 \mathrm{~km}$ to the southeast of Yakima (BPA Area Office Map, sheet 9,1975 ).

. Transportation Corridors or Facilities: The Yakima area is served by interstate route 82, U.S. routes 12 and 97 , and state routes 410,821 and 24. A11 the above lead into or pass through Yakima. State route 222 leads to Fort Simcoe. There are numerous other county roads in the area (Washington State Highway Commission Map, 1975).

Rail Jines into Yakima include lines operated by Union Pacific, Burlington Northern, and the Yakima Valley Transportation Company.

Air Service is provided by the Yakima Municipal Airport (Yakima East quadrangle, 7.5-minute series, 1953; Yakima West quadrangle, 7.5-minute series, $1958 \%$. 


\section{POPULATION}

..General Description of Population: The 1977 population of Yakima was 5i,100. Other cities in the area with substantial population include: Ellensburg, 13,000; Grandview, 4,400; Toppenish, 6,100; Sunnyside, 7,600; and Wapato, 3,060.

Yakima County has a population as of 1977 of 155,700 with a population density of 36.48. The population has increased by 10,488 since 1970 for an increase of approximately 6 percent (Washington Office of Financial Management, 1977).

$\therefore$ Economics

..Present Land Use: Primary land use is in agriculture or agriculture related activities. Crops include grains, fruit, and sugar beets. Stock raising is also of major importance.

..Future Land Use: The area is expected to remain primarily an agricultural area. 
( 
137

OLYMPIC AND SOL DUE HOT SPRINGS 
FIGURE 11 - GEOTHERMAL LAND CLASSIFICATION MAP

OLYMPIC AND SOL DUC HOT SPRINGS

•

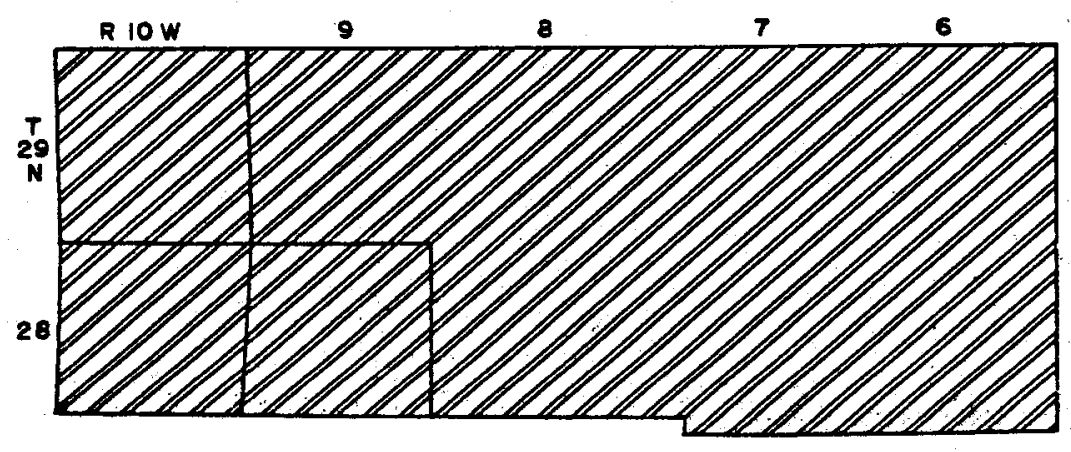

LEGEND

AREA OF KNOWN WARM WATER USE

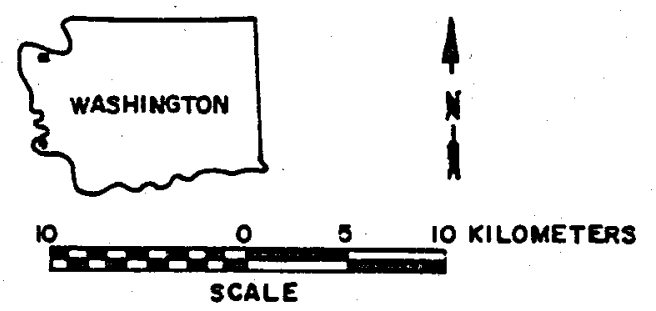

Base map: U.S. Geological. Survey Geothermal Lond

Classificotion Mop, Woshington, 1974 


\section{OLYMPIC AND SOL DUC HOT SPRINGS}

\section{Introduction}

The area encompassing 01 ympic and Sol Duc Hot Springs includes 207,360 acres within the boundaries of the 01 ympic National Park and 23,040 acres of forest service land. The study area is in the north-central portion of the 0lympic Peninsula, on the northern margin of the 0lympic Mountains, in Clallam County southwest of Port Angeles.

The area, al though not within a PGRA (Potential Geothermal Resource Area), as designated by the U.S. Geological Survey, is at present receiving a great deal of attention at the state and local levels.

The rectilinear location of the two hot spring areas is as follows: Olympic Hot Springs, SWl/4 sec. 29, T. 29, N., R. $07 \mathrm{~W}$; and Sol Duc Hot Springs, SW1/4 sec. 32, T. $29 \mathrm{~N}$., R. $09 \mathrm{~W}$. The present, as well as the future, land use will be recreational and educational because of its presence within the 0lympic National Park. Topographically the area is dominated by the 0lympic Mountains and elevations reach 1,371.6 m.

That portion of the area which is in the Olympic National Park is closed to private leasing and development through provisions of the Geothermal Steam Act of 1970.

Since no interest has been expressed in areas outside the national park boundaries, these areas are not considered by this report.

At one time both 0lympic and Sol Duc Hot Springs were developed resorts with pools and overnight accomodations. In the 1960 's, the Park Service decided to return 0lympic Hot Springs to its natural setting and the hotel and pools were removed. The area is now open to camping and the springs are available for bathing. Sol Duc Hot Springs has retained its developed status, and at present consists of one mineral and one fresh water pool, 62 overnight accomodations, an inn with cafe and restaurant, and camping and RV facilities. Energy consumption is primarily for space heating; the cabins, the inn, and the motel use a combination of gas, wood, and electric heaters. The fresh water pool is at present unheated except by natural solar radiation. The mineral pool is unheated, but it is kept at $\mathrm{ca} .38^{\circ} \mathrm{C}$ by the inflow of hydrothermal water.

Plans to upgrade and modernize the facilities at Sol Duc by the park service are now under consideration. It has not been determined whether the surface temperature and existing flow are sufficient for geothermally heating a fresh water pool, providing space heating for new overnight accommodations, and maintaining the temperature of a thermal-mineral pool of comparable size to the one now in use. If it is determined that present flow and temperature are not sufficient, then a thorough geological and geophysical assessment of the area will have to be undertaken in order to determine where a well should be drilled in order to increase flow and hopefully reach waters of higher temperature. Reservoir temperatures have been estimated at $90^{\circ}$ to $150^{\circ} \mathrm{C}$ by geothermometry. If water in this temperature range is encountered, there is no question that the facilities can be geothermally heated successfully. 
Space heating and the heating of swimming pools geothermally has been demonstrated to be efficient and economically comparable with other energy types in Klamath Falls, Oregon, and in several localities in Iceland, using water of comparable temperatures.

The feasibility of using the present hydrothermal water supply for upgrading the facilities should be completed by early 1979. If it is determined that the resource is not sufficient for planned uses and that a geological/geophysical assessment is found to be needed and desirable, then such an assessment could begin by mid-1979 and be completed by 1980 if sufficient funding is available.

In addition to the engineering and geological/geophysical investigations which have been discussed, the environmental impact of any such upgrading project will have to be assessed. The area, though environmentally sensitive, should not require an extensive environmental impact statement due to the modest changes that are being considered and the minimum impact that such changes would be expected to have on the environmental quality of the study area.

Any environmental statement that is required should be done simultaneously with the other feasibility studies, and all investigations should be completed by mid-1980, at which time future plans for the area should be finatized.

The facilities at Sol Duc Hot Springs could be totally geothermally heated by 1981 with a total energy saving greater than the guideline figure of 40 percent, which is required of all new federal facilities. The geothermal heating of the resort would also allow for the yeararound operation of the facilities.

In addition to the interest which the Park Service has expressed, local groups have organized for the purpose of ensuring that Sol Duc Hot Springs is retained as a developed resort. 
SITE DATA SUMMARY

SITE: Olympic and Sol Duc Hot Springs

..Physical Reservoir Data

..Temperature ${ }^{\circ} \mathrm{C}$

Surface: Olympic $26^{\circ}-48^{\circ} \mathrm{C}$

So 1 Duc $8.5^{\circ}-56^{\circ} \mathrm{C}$ (Schuster, personal communication, 1978)

Subsurface: 01 ympic-Na-K-Ca $143^{\circ} \mathrm{C}$

$\mathrm{S} 10_{2}-75^{\circ}-148^{\circ} \mathrm{C}$

Sol Duc-Na-K-Ca $131^{\circ}-140$

Si $2_{2}-105^{\circ}-148^{\circ} \mathrm{C}$ (Schuster, personal

communication, 1978)

..Total Dissolved Solids (PPM): 01ympic ca. $580 \mathrm{ppm}$.

Sol Duc ca. 270 ppm.

..Estimated non-Electric Energy Potential (MBtuh 30 years): No estimate is possible.

..Type of Overlying Rock: Mesozoic and Tertiary volcanics

(Tabor and Cady, 1978b).

...Estimated Depth to Top of Reservoir (meters): No estimate is possible.

..Site Land Status

Total Acres Ca. 230,400

FED. STATE PRIVATE OTHER

Total Acres Leased None

..Geothermal Development Status: At the present time, Sol Duc Hot Springs is being utilized by the 01ympic National Park for recreational uses. The thermal water is available for bathing, and cabins and a campground are available to overnight guests.

At one time 0lympic Hot Springs also experienced some development, but the 01 ympic National Park directors have removed all buildings and the hot springs are now available only to campers. The loss of significant portions of the flow and resulting health risks are the primary reason stated for the closing by the Olympic National Park personnel.

..Local and State Attitude Toward Geothermal Development: The State of Washington Department of Natural Resources and the Washington Energy Office are now in the process of developing a statewide plan for geothermal assessment and development.

The area to the north of Olympic Hot Springs and Sol Duc Hot Springs and outside the boundaries of the Olympic National Park is one of several areas being considered for assessment work. 
Environmental issues will have to be given careful consideration because of the close proximity that any development would have to the 0lympic National Park.

The park service is also interested in continued and expanded use of Sol Duc Hot Springs. The feasibility of using the waters for space heating is now under consideration (Coleman, 1978).

..Land Use and Population: Both 0Iympic and Sol Duc Hot Springs lie within the boundaries of 0lympic National Park, and this area is one of the higher recreational use areas of the park. To the north of the park is a combination of private, forest service and state lands which are primarily used for timber production and recreation (U.S. Forest Service 01ympic National Forest and Park Map, 1977).

Population densities are low. Port Angeles with 16,890 persons is the only major city within the area (Washington Office of Financial Management, 1977).

..Comments and Critical Issues: The area is located almost entirely within the boundaries of the 0lympic National Park, and a1l areas within National Park boundaries are excluded from commercial development by the Geothermal Steam Act of 1970 (Appendix I). Development outside the park on private, state, or national forest lands will be extremely environmentaliy sensitive.

A thorough geologic assessment of the area as to its geothermal potential is needed. 
SITE LOCATION AND PHYSICAL DESCRIPTION

..Latitude: Sol Duc Hot Springs - $47^{\circ} 58^{\prime}$

01 ympic Hot Springs $-47^{\circ} 59^{\prime}$

. Longitude: Sol Duc Hot Springs - $123^{\circ} 52^{!}$

Orympic Hot Springs - $123^{\circ} 41$ !

(Bogachiel Peak quadrangle, 15-minute series, 1950); (Mount Carrie, quadrangle, 15-minute series, 1950)

..Rectilinear: Sol Duc Hot Springs - NWI/4 sec 32 T. 29 N., 9 W. (Campbel1 et ar., 1970). $0 l$ ympic Hot Springs - SWT/4 sec. 29, T. 29 N. R. $7 \mathrm{~W}$

..County: Clallam

..Adjacent Counties: Jefferson (Washington State Highway Commission Map, 1975)

..Topography: So1 Duc Hot Springs 1 ies at approximately $518.2 \mathrm{~m}(1,700$ ft.) and 01ympic Hot Springs lies at approximately 628.2 $\mathrm{m}(2,061 \mathrm{ft}$.).

Sol Duc Hot Springs is located on the flood plain of the Sol Duc River with steep valley walls surrounding the area. Elevations reach $1,372 \mathrm{~m}$ $(4,500 \mathrm{ft}$.) within $2.4 \mathrm{~km}$ (1 1/2 miles). (Bogachiel Peak quadrangle, 15-minute series, 1950).

Olympic Hot Springs is located along Boulder Creek and is surrounded by steep valley walls. (Mount Carrie quadrangle, 15-minute series, 1950). The topography becomes less mountainous to the north.

..Present Land Use: All areas within the Olympic National Park are reserved for recreational and educational uses. Outside the park to the north, the primary land use is timber production and recreation.

..Future Land Use Plans: The recreational land use within the 0lympic National Park is expected to continue indefinitely. To the north of the park on state, federal and private lands, timber production and harvesting are expected to remain dominant with recreational uses being of significant importance.

.Aesthetics: The area is one of very high aesthetic value. Its location within or near the Olympic National Park gives added importance to the need for retention of the aesthetic quality of the area.

..Historical/Archaeological Significance: There are no known archeological sites, or sites of historical significance as recognized by the National Register of Historic places (Odegaard, 1976). 
..Geologic Description: The Olympic Peninsula is comprised of two major bedrock terranes: the core rocks and the peripheral rocks. The core rocks are open to the west but enclosed to the north, east, and south by the peripheral rocks. The peripheral rocks are folded and faulted, but are generally stratigraphically continuous. Ages range from early Eocene to late Miocene with patches of Pleistocene. Pleistocene and Holocene rocks are found in the study area along the coast and in the stream valleys. The core rocks are highly deformed and are penetratively sheared and metamorphosed in the pumpellyite and low greenschist facies. The age of the core rocks in the study area is much the same as in the peripheral sequence.

The principal core units include: Western 0lympic lithic assemblage Basaltic rocks-greenstone and greenschist Elwha lithic assemblage

The principal peripheral units include: Blue Mountain unit Cresent Formation

The majority of the rock units are of sedimentary origin al though volcanic rocks of primarily basaltic composition are found throughout the sequence as either flows or intrusions.

The area has undergone extensive faulting. Both high-angle and thrust faulting is common and major thrust faults are known or inferred at the boundary between the core and peripheral rocks (Tabor and Cady, 1978a).

.Geophysical Summary: The 0lympic Peninsula lies along the tectonically active margin of western North America and experiences a number of earthquakes yearly. It is believed that the 0lympic Peninsula region has been at or near the northeast corner of the Juan de Fuca plate for at least the last 5 million years. The presence of a major plate boundary, extending from the north end of the Juan de Fuca to the north end of the 0lympic Peninsula may have defined the present location of the Otympic range (Crosson, 1972).

Detailed geophysical work is lacking in the study area and is considered essential to an understanding of the complex structural relationships in the area.

..Geologic Hazards: Rasmussen (1967) places the area into his zone of potential moderate damage as a result of seismic activity. In addition to the seismic hazards, landslides and floods could occur in the area. 
RESERVOIR CHARACTERISTICS

. Reservoir Temperature

..Surface: Olympic Hot Springs $-26^{\circ}-48^{\circ} \mathrm{C}$

Sol Duc Hot Springs $-8.5^{\circ}-56^{\circ} \mathrm{C}$ (Campbell et az., 1970)

..Subsurface: 0lympic Hot Springs - Not Available

Sol Duc Hot Springs - Not Available

..Geochemical

$\mathrm{SiO}_{2}$ : Olympic Hot Springs $-75^{\circ}-148^{\circ} \mathrm{C}$

Sol Duc Hot Springs - $105^{\circ}-148^{\circ} \mathrm{C}$ (Schuster, personal communciation, 1978)

$\mathrm{Na}-\mathrm{K}$-Ca: 01 ympic Hot Springs $-143^{\circ} \mathrm{C}$

So 1 Duc Hot Springs $-131^{\circ}-140^{\circ} \mathrm{C}$

..Flow Rates: 01 ympic Hot Springs - $8.46 \mathrm{l} / \mathrm{s}$

Sol Duc Hot Springs - $3.13 \mathrm{l} / \mathrm{s}$ (Campbell et al., 1970)

..pH: Olympic Hot Springs - ca. 8.4

Sol Duc Hot Springs _ ca. 8 (Schuster, personal communcation, 1978)

. Total Dissolved Solids: Olympic Hot Springs ca. $580 \mathrm{ppm}$ Sol Duc Hot Springs ca. 270 ppm

(Schuster, personal communication, 1978)

..Fluid Chemistry:

$\begin{array}{lc} & \text { Olympic Hot Springs } \\ \mathrm{Cl} & 0.4-0.7 \mathrm{ppm} \\ \mathrm{Na} & 39-79 \mathrm{ppm} \\ \mathrm{K} & 0.7-1.5 \mathrm{ppm} \\ \mathrm{Ca} & 1.4-3.6 \mathrm{ppm} \\ \mathrm{SiO}^{2} & 30-120 \mathrm{ppm}\end{array}$

Sol Duc Hot Springs

$1.7-17 \mathrm{ppm}$

$80-84 \quad \mathrm{ppm}$

$1.2-2.6 \mathrm{ppm}$

$1.7-2.6 \mathrm{ppm}$

$\mathrm{Si}^{2} \quad 30-120 \quad \mathrm{ppm}$

$58 \quad-120 \quad \mathrm{ppm}$

(Schuster, personal communciations, 1978)

..Estimated Nonelectric Energy Potential (MBtuh 30 years): No estimate is possible until further geologic assessment of the area is completed.

.Subsurface Area of Reservoir: No information is available at this time. 
..Land Ownership

ca. 230,400

TOTAL AREA FEDERAL STATE PRIVATE OTHER

(Acres) (Acres) (Acres) (Acres) (Acres)

..Land Leased

None None

..Highest priced leases

(Dollar/Acre)

N/A

N/A

.. \$/Acrè Lessee

N/A N/A

..Tentative Lease Sale Dates:

None None

... Number of Sales

Offered But No Bids: N/A N/A

.. Number of Bids Rejected

(Resulting in No Lease): N/A

...Summary of Leasing Status and Needs: Leasing within 0lympic National Park under provisons of present law is impossible (Geothermal Steam Act, 1970) (Appendix I).

Leasing of National Forest lands is under the jurisdiction of BLM, but cannot take place until an environmental statement is prepared and okayed by the forest service. At the present time, no environmental statement is being completed by the forest service and none is planned.

No provision for the leasing of state lands has been made under Washington law. 
..Present Development Status: Sol Duc Hot Springs is presently being used for recreational purposes. A large swimming pool filled with the warm $53.3^{\circ} \mathrm{C}\left(128^{\circ} \mathrm{F}\right)$ mineral water is being operated by a concessionaire for the park service. Overnight accommodations are available in the form of cabins, motel units, and camping and RV sites. Meals and supplies are available at the Inn.

0lympic Hot Springs, which once experienced some development, has been allowed to return to nature by the park service. Hiking in the area is popular as is bathing in the hot springs.

..Projected or Planned Development: At the present time, the park service is looking into the feasibility of upgrading the facilities at Sol Duc Hot Springs. Any planned development will depend upon the availability of geothermal water for continued use in the swimming pool and for space heating of new overnight accommodations which the park service would like to build to replace the existing accommodations (Coleman, personal communication, 1978).

There is no known planned or projected development outside the park boundaries. Any future development will be dependent upon the outcome of a thorough geological assessment of the area. 


\section{INSTITUTIONAL CHARACTERISTICS}

.institutional Requirements: the Geothermal Steam Act of 1970 (Appendix I) precludes the leasing of national park lands.

Forest service lands cannot be leased until after the preparation and acceptance of an environmental statement covering the lands in question.

The question of the ownership of geothermal resources on state and private lands is under consideration as is the question of leasing of state lands.

..Agency and Public Attitudes: The 01ympic National Park Superintendent has expressed an interest in the increased use of the geothermal resources within the park and a desire to upgrade the facilities available for the public enjoyment of the resources.

Environmental statements have been receiving low priority by the forest service, and no statement is proposed for this area.

The Washington Department of Natural Resources and the Washington Energy Office are at present very interested in developing plans for geologic assessment and eventual devel opment of the state' $s$ geothermal resources.

Private groups are presently working for the retention of Sol Duc Hot Springs as a developed recreational area.

..Status of Requirement (i.e., EIA/EIS No plans are now under consideration concerning the preparation of an environmental statement on the federal lands concerned.

At present the Washington Department of Natural Resources and the Washington Energy office are looking at institutional factors affecting geothermal exploration and development. It is hoped that it will be possible to have requirements accepted, and leasing procedures developed, within the next two year. 


\section{ENVIRONMENTAL FACTORS}

..Cl imate

..Prevailing Winds: Prevailing winds are from west (Phillips, 1966).

..Precipitation (Annual): Mean annual precipitation at Port Angeles is $757 \mathrm{~mm}$ (29.81 in.), and Elwha R.S. 1,421 mm (55.94 in.). Highest precipitation is from November to February (Phillips, 1966).

..Days of Sunshine (Annual): No information is available.

. Average Temperature: Mean annual temperature is $8.2^{\circ} \mathrm{C}\left(46.7^{\circ} \mathrm{F}\right)$ at Port Angeles and $9.3^{\circ} \mathrm{C}\left(48.7^{\circ} \mathrm{F}\right)$ at Elwha R.S. (Phillips, 1966).

Minimum: Mean minimum temperature at Port Angeles is $4.4^{\circ} \mathrm{C}$ $\left(39.9^{\circ} \mathrm{F}\right)$ and $4.1^{\circ} \mathrm{C}\left(39.3^{\circ} \mathrm{F}\right)$ at Elwha R.S. (Phillips, 1966).

Maximum: Mean maximum temperature at Port Angeles is $12.0^{\circ} \mathrm{C}$ $\left(53.6^{\circ} \mathrm{F}\right)$ and $14.4^{\circ} \mathrm{C}\left(58.0^{\circ} \mathrm{F}\right)$ at Elwha R.S. (Phillips. 1966).

. Degree Days (Annual): Port Angeles has 5,922 heating degree days on a base of $18.3^{\circ} \mathrm{C}\left(65^{\circ} \mathrm{F}\right)$ (Phillips, 1966).

.. Relative Humidity (Seasonal Peaks) (At Port Angeles)

Summer: $\quad 043089$ percent $\quad 163076$ percent

Winter: 043082 percent $\quad 163077$ percent

(Phillips, 1966)

.. Air Quality: Air quality is very high in the Olympic National Park and the surrounding 0lympic National Forest. Ma in pollutants in the forest would be in the form of dust from timber harvesting operations and smoke from controlled or uncontrolled fires. In the Port Angeles area pollutant levels increase and are primarily from pulp mills, plywood mills, and saw mills. Pollutants are in the form of dust and smoke.

..Water Quality: The quality is very high. Streams in the national park and forest are rated as Class $A A$ (extraordinary). (Washington Administrative Code [WAC] Chapter 173-201 WAC; James, personal communication, 1978)

.. Noise: Ambient noise levels are low. Some noise pollution can be expected on state, private, or forest lands as a result of timber harvesting.

\section{...Biological}

..Dominant Flora: The area lies divided between the Humid Transition and the Canadian and Hudsonian Life Zones.

The species which dominate in the Humid Transition Life Zone include: western hemlock Tsuga heterophyzla, Douglas fir Pseudotsuga 
taxifolia. and red cedar Thuja plicata. Locally the western yew Taxus brevifolia, lodgepole pine Pinus contorta, and spruce Picea sitchensis may be common. Deciduous trees include: willows Salix sp., aspen Populus tremuloides, hazel Corylus califormica, alder Alnus oregona, oak Quercus garryan, broadleaf maple Acer macrophy Zlzm, vine maple Acer circinatum, and flowering dogwood Comus nuttallii. Ferns, especially the sword fern Polystichum muitum and bracken fern Pteridium aguilinum, are common. The most common shrubs include: huckleberry Vaccinium parvifolium, Vaccinium ovatum, Oregon grape Berberis nemosa, salal Gaultheria shallon, rose Rosa zymnocarpa, thimbleberry Rubus parviflorus, salmonberry Rubus spectabilis, blackcap raspberry Rubus leucodermis, and wild blackberry Rubus macropetalus.

The Hudsonian species include: alpine fir Abies Zasiocarpa, mountain hemlock Tsuga mertensiana, Alaska cedar Chamaecyparis nootkatensis, and white-barked pine Pinus albicaulis. Numerous shrubs are also common to this zone.

The Canadian species include: Douglas fir Pseudotsuga taxifolia, western hemlock Tsuga heterophy Zla, amabaslis fir Abies amabalis, white pine Pinus monticola, and noble fir Abies nobilis. "Other species common to the zone are: Vaccinnium ovalifolium, Vaccinnium membranaceum, Menziesia fermuinea, Alnus sinuata, Acer ciricinatum, Sorbus cascadensis, Cormus canadensis, Clintonia uniflora, Stenauthium occidentale, Galium oreganum, and Prenanthes lessingii. (U.S. Army Corps of Engineers, 1973)

..Dominant Fauna: Dominant mammals include: elk, blacktailed deer, black bear, wolf Canis lupus fuscus, cougar, mountain goat, cinereous shrew Sorex cinereus streatori, and long-eared myot is Myotis evotis pacificus. Fowl include: western goshawk, valley quail, snipe, dove, blue grouse, ruffed grouse, ring-necked pheasant (Chinese), and band-tailed pigeon.

..Endangered, Rare, Remnant, Unique or Otherwise Significant Species:

..Flora: Tree specimens--Evergreen: western red cedar Thuja plicata, coast Douglas fir Pseudotsuga menziesii, var. menziesii, Pacific silver fir Abies amabilis and subalpine fir Abies Zasiocarpa, var. Zasiocarpa.

..Fauna: Long-eared bat Corynorhinus rafinesquii townsendii, fisher Martes pennanti, $01 y$ mpic marmot Marmota olympus, mountain goat Oreamis americanus, mountain lion Felis concolor, and wolf Canis Zupus fuscus. The 01 ympic wolf Canis lupus olympus may be extinct. The area also includes important elk range and anadromous fish routes Salmonid. (U.S. Army Corps of Engineers, 1973) 
..Utility or Energy Transmission Corridors and Facilities:

One 69/115 KV line approximately $19 \mathrm{~km}$ (12 miles) north--owned by BPA One $69 \mathrm{KV}$ line approximately $19 \mathrm{~km}$ (12 miles) north--owned by Clallam Co. PUD

One $69 \mathrm{KV}$ line approximately $7 \mathrm{~km}$ ( 4.4 miles) east--owned by Crown Zellerbach Corp.

One $230 \mathrm{KV}$ line approximately $22 \mathrm{~km}$ ( 13.7 miles) northeast--owned by BPA (BPA Area office map. Sheet 5, 1974)

..Transportation Corridors or Facilities: The main route is U.S. 101 which is approximately $16 \mathrm{~km}$ (10 miles) from 0lympic Hot Springs and $17.6 \mathrm{~km}$ (11 miles) from Sol Duc Hot Springs. Within the Olympic National Park, park service roads reach the hot springs. Outside the National Park, forest service and county roads service the area. (0lympic National Park, Forest Map, 1977) (Washington State Highway Commission Map, 1976) 
..General Description of Population: The population of the area is low and widely scattered. The total population of Clallam County as of 1977 was 41,100. The population density was 23.44 per square mile. The population has increased by approximately 10 percent since 1970. The population of the other counties which could be affected has experienced increases of between 10 to 15 percent since 1970 .

The only major population center which could be served is Port Angeles with an 1977 population of 16,890.

Employment is primarily in manufacturing with 33.7 percent of the population engaged in this field. Retail trade accounts for 20.9 percent of the work force, services 15.7 percent, and government (local, state and federa1) accounting for 12.1 percent (Washington Office of Financial Management, 1977).

..Economics

..Present Land Use: The primary land use in Olympic National Park is recreation. Outside the Park, timber production is dominant, and it forms the economic base for the region. Pulp, plywood, and saw mills are the largest employers in the area.

..Future Land Use: It can safely be assumed that land use patterns and the economic base of the area will not change. 
LEGAL AND INSTITUTIONAL FACTORS AFFECTING

GEOTHERMAL ASSESSMENT AND DEVELOPMENT IN WASHINGTON

Introduction

The legal and institutional factors which have affected and which will continue to affect the assessment and development of the state's geothermal resources can logically be separated into the realms of state and federal responsibilities. However, one overriding factor which has played a major role in regard to both state and federal activities is inadequate knowlege of the state's geothermal potential.

This lack of knowledge is reflected in the perceived low priority by the state legislature in the resolution of the question of ownership of geothermal resources on state and private lands, and the failure to adopt procedures for obtaining exploration permits and/or leases on state lands, to name but a few of the factors that need to be addressed. This same lack of knowledge has resulted in a low priority being given to the preparation of environmental statements by the responsible federal agency in regard to the leasing of federal lands for geothermal exploration and development.

\section{Federal}

The Geothermal Steam Act of 1970 (P.L. 91-581, Appendix I) authorizes the Secretary of the Interior to issue leases for the development and utilization of geothermal steam and associated geothermal resources on lands administered by the Departments of Interior and Agriculture. The Secretary is also authorized to prescribe such rules and regulations as are deemed appropriate in order to carry out the provisions of the Geothermal Steam Act of 1970.

Lands in any known geothermal resource area (KGRA) must be leased by the Secretary of the Interior through competitive bidding. Lands not in KGRA will be leased to the first qualified person making application.

The acceptance of lease applications began in January, 1974, and as of January 1, 1978, 238 lease applications had been filed with BLM. This accounted for a total of 491,728 acres. Competitive interest in obtaining leases resulted in the classification of 14,680 acres as being in KGRA's. Three KGRA's were established in the state by the U.S. Geological Survey on the basis of geological evidence or because of competitive interest. The three KGRA's are Indian Heaven $(2,547$ acres), Mount St. Helens $(29,755$ acres), and Kennedy Hot Springs $(3,331$ acres). This 1 and was to be offered in lease sales at the earliest possible time by the BLM. To date, no lease sales have been held although a lease sale is tentatively scheduled for Indian Heaven KGRA for 1979.

The remaining 477,048 acres upon which lease applications were filed are still awaiting action.

The failure to grant leases or to hold lease sales is a result of the nonfulfillment of the surface management agencies' responsibility to prepare environmental statements (ES's) in regard to geothermal leasing 
and development. In the case of Washington, a11 lands in question are under forest service management.

The failure of the forest service to prepare the necessary ES's is a combination of lack of budget and personnel, and a result of the low priority which geothermal has received from the forest service. The low priority is a direct result of the lack of knowledge of the potential geothermal resources underlying forest service administered lands. This lack of knowledge has had another unfortunate effect on the leasing procedure.

The first draft ES was released by the forest service in January, 1978. The author of the ES, although extremely thorough in his treatment of all known resources of the study area, was forced to base the potential impact of geothermal leasing and development on a worst possible case because of lack of knowledge of the geothermal potential. This resulted in the forest service's preferred alternative being highly restrictive in regard to geothermal leasing.

In addition, federal regulations concerning the establishment of KGRA's have discouraged pre-lease exploration by industry. Pre-lease exploration could have resulted in extensive exploratory work being carried out on federal lands. Pre-lease exploration which involves only "casual use". does not require a permit and may be conducted after notifying the Geothermal Supervisor of the Geological Survey. (Casual use involves nondestructive activities only.) In addition, an operator may secure approval from the Geothermal Supervisor for the drilling of heat-flow holes, and the use of other intensive exploratory techniques under a "Notice of Intent and Permit to Conduct Exploration Operation." However, casual use and exploration conducted under a Notice of Intent are not exclusive rights, nor do they confer any preferential rights to a geothermal lease. In the case of a lease applicant conducting exploratory work on lands for which he/she has applied for lease, the results of such work which results in a discovery could result in the area being classified as a KGRA by the U.S. Geological Survey. This would result in the application being rejected and the land would be leased competitively. It is not, therefore, in the interest of the lease applicant to commit large sums of money to exploration until after the issuing of leases.

Therefore, only through a greatly accelerated geological assessment program by state and federal agencies can the required knowledge of the resource potential of the state can be provided. And, it is only through the availability of this information that realistic environmental statements can be prepared and thus allow for the leasing of federal lands for exploration and development.

\section{State}

The State of Washington has failed at both the executive and legislative levels to confront the needs of geothermal. Again, it is the lack of knowledge concerning the state's geothermal resource potential to which this can be attributed. Neither the executive nor the legislative branches are expected to make the needed commitments to the needs of geothermal until such time as a definite indication of the availability 
of geothermal resources is established. However, this lack of direction by the state and the failure of the state to adopt legislation vital to the promotion of exploration and development has, in conjunction with the inaccessibility of federal lands, resulted in only cursory interest in the state by private industry.

At present, only House Bill No. 135 (Appendix II) has been passed. This bill is for the sole purpose of the regulation of the drilling and operation of wells for geothermal resources. The definition of geothermal, as stated in the bill, is for purposes of this bill only. The bill clearly, for purposes of regulation, separates the responsibility of regulation between the Department of Natural Resources (DNR) and the Department of Ecology (DOE). DNR is given the responsibility for regulating all activities where the actual or anticipated resources are capable of producing electricity using state-of-the-art technology. Resources from which it is not technologically practical to derive the energy to produce electricity commercially are to be under the jurisdiction of DOE, and the resource is subject to any and all applicable laws and regulations relating to wells drilled for appropriation and use of ground water.

Many issues, however, remain unsettled and their resolution will have a profound influence upon whether or not industry commits substantial resources to the exploration and development of geothermal resources in the state.

The issues requiring immediate attention include (1) the development of a clear and concise definition of geothermal resources which serves to distinguish geothermal resources from other resources and allows for the resolution of the question of ownership; (2) the adoption of rules and regulations for obtaining pre-lease exploration permits and the resolution of the question of whether or not such a permit confers preferential rights to a geothermal lease; and (3) the adoption of leasing rules and regulations.

The granting of leases involves the transfer of public resource rights to private developers and thus should provide for the maximum public benefit from exploration of the resource while at the same time allowing for the economical development of the resource by private industry. A number of factors must therefore be taken into consideration. These factors include: (1) should leases be granted on a competitive or noncompetitive basis, and if competitive bidding is used, should the bidding take the form of cash bonuses or profit shares; (2) what acreage limitations should be imposed taking into consideration the differing needs of electrical and nonelectrical utilization and should these limitations reflect only the number of acres not in production; (3) what percentage of income from production should be paid in the form of royalties and what should the minimum rental fee be; (4) what should be the primary lease term and what requirements should be in effect in order to assure diligent exploration and development by the leasee; (5) what provisions should be made for renewal of leases for continued production in order to provide maximum protection to the developer while at the same time providing for a fair portion of the public resource value reaching the public treasury. 
It can thus be concluded that the timely and orderly development of Washington's geothermal resources can be accomplished only by an aggressive geologic assessment program by state and federal agencies and an energetic legislative program at the state level. 


\section{SELECTED REFERENCES}

Bodvarsson, G.; Mosecar, R. S., 1971, Heat flow through the floor of Cascade Basin: Journal of Geophysical Research, v. 76, no. 20, p. . 4759-4773:

Braile, L. W., 1970, The isostatic conditions and crustal structure of Mount St. Helens as determined from gravity data: University of Washington M.S. thes is, $37 \mathrm{p}$.

Brown, R. D.; Snavely, P. D., Jr.; Gower, H. D., 1960, Geology of the Port Angeles-Lake Crescent area, Clallam County, Washington: U.S. Geological Survey $0 \mathrm{il}$ and Gas Investigations Map OM-203.

Campbel1, K. V.; Miers, J. H.; Nichols, B. M.; 01iphant, Jerrelyn; Pytlak, Shirley; Race, R. W.; Shaw, G. H.; Gresens, R. L., 1970, A survey of thermal springs in Washington State: Northwest Science, v. 44, no. $1,11 \mathrm{p}$.

Coleman, J. W., Jr., 1978, (Personal communication): U.S. National Park Service Olympic National Park.

Coombs, H. A., 1936, The geology of Mount Rainier National Park: University of Washington, Publications in Geology, v. 3, no. 2, p. 131212.

Coombs, H. A., 1939, Mount Baker, a Cascade volcano: Geological Society of America Bulletin v. 50 , no. 10, p. 1493-1509.

Couch, R. W., 1969, Gravity and structures of the crust and sub-crust west of Washington and British Columbia: Oregon State University Ph.D. thesis, Corvallis, $190 \mathrm{p}$.

Crandell, D. R.; Mullineaux, D. R., 1967, Volcanic hazards at Mount Rainier, !lashington: U.S. Geological Survey Bulletin 1238, 26 p.

Crande11, D. R.; Mullineaux, D. R., 1973, Pine Creek volcanic assemblage at Mount St. Helens, Washington: U.S. Geological Survey Bulletin 1383-A, 23 p.

Crandell, D. R.; Mullineaux, D. R.; Hyde, J. H., 1976, Potential hazards from Mount Baker volcano, Washington: U.S. Geological Survey, Memorandum, 4 p.

Crande11, D. R.; Mullineaux, D. R.; Miller, R. D.; Meyer, Rubin, 1962, Pyroclastic deposits of Recent age at Mount Rainier, Washington: U.S. Geological Survey Professional Paper 450-D, p. D64-D68.

Crande11, D. R.; Mullineaux, D. R.; Meyer, Rubin, 1975, Mount St. Helens volcano - Recent and future behavior: Science, v. 187, p. 438-441. 
Crande11, D. R.; Waldron, H. H., 1956, A Recent volcanic mudflow of exceptional dimensions from Mount Rainier, Washington: American Journal of Science, v. 254, p. 349-362.

Crosson, R. S., 1972, Sma11 earthquakes, structures, and tectonics of the Puget Sound region: Seismological Society of America Bulletin, v. 62 , no. 5 , p. 1133-1171.

Crosson, R. S.; Millard, R. C., 1974, Compilation of earthquake hypocenters in western Washington: Washington Division of Geology and Earth Resources Information Circular 53, $25 \mathrm{p}$.

Crosson, R. S., 1975, Compilation of earthquake hypocenters in western Washington: Washington Division of Geology and Earth Resources Information Circular 55, $14 \mathrm{p}$.

Crowder, D. F.; Tabor, R. W.; Ford, A. B., 1966, Geologic map of the Glacier Peak quadrangle, Snohomish and Chelan Counties, Washington: U.S. Geological Survey Geologic Quadrangle Map GQ-473. Scale $1: 62,500$.

Cullins, H., 1977, Known geothermal resource areas (KGRA's) as classified by the area geologists, western and central regions: U.S. Geological Survey, $15 \mathrm{p}$.

Danes, Z. F.; Bonno, M. M.; Brau, E.; Gilham, W. D.; Hoffman, T. F.; Johanson, D.; Jones, T. H.; Malfait, D.; Mastem, J.; Teague, G. 0., 1965, Geophysical investigations of the southern Puget Sound area, Washington: Journal of Geophysical Research, v. 70, p. 55735580 .

Drysdale, F. F.; Calef, C. E., 1977, The energetics of the United States of America: Biomedical and Environmental Assessment Division National Center for Analys is of Energy System, Brookhaven National Laboratory Associated Universities, Inc., 439 p.

Fiske, R. S.; Hopson, C. A.; Waters, A. C. 1963, Geology of Mount Rainier National Park, Washington: U.S. Geological Survey Professional Paper 444, $93 \mathrm{p}$.

Folsom, M. M., 1970, Volcanic eruptions - The pioneer's attitude on the Pacific coast, from 1800 to 1875: Oregon Department of Geology and Mineral Industries, The Ore Bin, v. 32, no. 4, p. 61-71.

Ford, A. B., 1959, Geology and petrology of the Glacier Peak quadrangle, Northern Cascades, Washington: University of Washington, Ph.D. thesis, $374 \mathrm{p}$.

Fournier, R. 0.; Rowe, J. J., 1966, Estimation of underground temperatures from the silica content of water from hot springs and wet-steam wells: American Journal of Science, v. 264, p. 685-697. 
Fowler, C. S., 1935, Origin of the sulphur deposits of Mount Adams: Washington State College M.S. thesis, 23 p.

Fowler, C. S., 1936, The geology of the Mount Adams country: Geological Society of the Oregon Country, The Geological Newsletter, v. 2, no. 1, p. $2-5$.

Frank, D.; Post, A.; Friedman, J. D., 1975, Recurrent geothermally induced debris avalanches on boulder glaciers, Mount Baker, Washington: U.S. Geological Survey, Journal of Research, v. 3, no. 1, p. 77-87.

Frank, D.; Heier, M. F.; Swanson, D. A., 1977, Assessment of increased thermal activity at Mount Baker, Washington, March 1975 - March 1976, with contributions by J. W. Babcock, M. O. Fretwel1, G. D. Malone, C. L. Rasenfeld, R. L. Shrene, and R. E. Wilcox: U.S. Geological Survey Professional Paper 1022-A, $49 \mathrm{p}$.

Gizienski, S. F.; McEuen, R. B.; Birkhahn, P. C., 1975, Regional evaluation of the geothermal resource potential in central Washington State: Washington Public Power Supply System, Richland, Washington, OpenFile Report, 113 p.

Haley, D., 1970, Hashington's five volcanoes - Quiet but not extinct: Pacific Search unbound insert no. 22, 2 p.

Hammond, P. E., 1973, Preliminary geologic maps of the southern Cascade Range, Washington: Washington Division of Mines and Geology OpenFile Report $73-3,5$ sheets.

Hopson, C. A., 1971, Eruptive sequence at Mount St. Helens, Washington: Geological Society of America Abstract with Programs, v. 2, no. 2, p. 138.

Hopson, C. A.; Waters, A. C.; Bender, V. R.; Meyer, Rubin, 1962, The latest eruptions from Mount Rainier volcano: Journal of Geology v. 70, no. 5, p. $635-647$.

Hopkins, K., 1976, Geology of the south and east slopes of Mount Adams volcano, Cascade Range, Washington: University of Washington:

Ph.D. thes is, $143 \mathrm{p}$.

Huntting, M. T.; Bennett, W. A. G.; Livingston, V. E., Jr.; Moen, W. S., 1967, Geologic map of Washington: Washington Division of Mines and Geology, scale 1:500,000.

Hutchins, J. N., 1978 (personal communication): U.S. Forest Service Gifford Pinchot National Forest.

Hyde, J. H., 1970, Geologic setting of Merrill Lake and evaluation of volcanic hazards in the Kalama River valley near Mount St. Helens, Washington: U.S. Geological Survey Open-File Report, 15 p. 
Hyde, J. H., 1973, Late Quaternary volcanic stratigraphy, south flank of Mount St. Helens, Washington: University of Washington Ph.D. dissertation, $114 \mathrm{p}$.

Hyde, J. H., 1975, Upper Pleistocene pyroclastic-flow deposits and lahars south of Mount St. Helens Volcano, Washington: U.S. Geological Survey Bulletin 1383-B, $20 \mathrm{p}$.

Hyde, J.H.; Crandel1, D. R., 1975, Origin and age of post-glacial deposits and assessment of potential hazards from future eruptions of Mount Baker, Washington: U.S. Geological Survey Open-File Report 75-286, 22 p.

Hyde, J. H.; Crandell, D. R., 1978, Postglacial volcanic deposits at Mount Baker, Washington, and potential hazards from future eruptions: U.S. Geological Survey Professional Paper 1022-C, 17 p.

James, R., 1978 (personal communication): Washington Department of Ecology.

Kline, G. L., 1977, Endangered, threatened, rare and declining species in Washington State: U.S. Fish and Wildlife Service, memorandum, $6 \mathrm{p}$.

Korgen, B.:J.; Boduarsson, G.; Mesecar, R. S., 1971, Heat flow through the floor of Cascadia Basin: Journal of Geophysical Research, vol. 76 , no. 20, p. $4758-4774$.

Landes, H., 1917, A geographic dictionary of Washington: Washington Geological Survey Bulletin no. 17, $346 \mathrm{p}$.

Lawrence, D. B., 1939, Continuing research on the flora of Mount St. Helens: Mazama, v. 21, no. 12, p. 49-54.

Mackin, J. H., 1961, A stratigraphic section in the Yakima Basalt and the Ellensburg Formation in south-central Washington: Washington Division of Mines and Geology, Report of Investigation no. 19, $45 \mathrm{p}$.

McWilliams, R. G., 1970, Evidence for thrust faulting in northern 01ympic Peninsula, Washington: American Association of Petroleum Geologists Bulletin, v. 54, no. 2, p. 344-356.

Moxham, R. M., 1970, Thermal features of volcanoes in the Cascade Range as observed by aerial infrared surveys: Volcanologique Bulletin, v. 34 , no. 1, p. 77-106.

Moxham, R. H.; Crandel1, D. R.; Marlatt, W. E., 1965, Thermal features at Mount Rainier, Washington, as revealed by infrared surveys: U.S. Geological Survey Professional Paper 525-D, p. D93-D100.

Mullineaux, D. R.; Crande11, D. R., 1960, Late Recent age of Mount St. Helens volcano, Washington, U.S. Geological Survey Professional Paper, 400-B, p. B307-B303. 
Mullineaux, D. R.; Crandell, D. R., 1962, Recent lahars from Mount St. Helens, Washington: Geological Society of America Bulletin, v. 73, p. $855-970$.

Mullineaux, D. R.; Hyde, J. H.; Meyer, Rubin, 1972, Widespread late glacial and postglacial tephra deposits from Mount St. Helens volcano, Washington: U.S. Geological Survey Journal of Research, v. 3, no. 3, p. $329-335$.

Northwest Energy Policy Project, 1978, Energy futures northwest - Northwest Energy Policy Project final report: Northwest Energy Policy Project, Portland, Oregon, 174 p.

Odegaard, C. H., 1976, Preserving Washington's history - A bicentennial report: Washington State Parks and Recreation Commission, $92 \mathrm{p}$.

Pavoni, N., 1966, Tectonic interpretation of the magnetic anomalies southwest of Vancouver Island: Pure Appl. Geophysics, v. 63, p. 172.

Phillips, E. L., 1960, Climates of the states - Washington: U.S. Department of Commerce, Weather Bureau, no. 60-45, $28 \mathrm{p}$.

Phillips, E. L., 1964, Washington climate for these counties - Clark, Cowlitz, Lewis, Skamania, and Thurston: Washington State University Cooperative Extension Service, $42 \mathrm{p}$.

Phillips, E. L., 1966, Washington climate for these counties - Clallam, Jefferson, Island, San Juan, Skagit, Snohomish, and Whatcom: Washington State University Cooperative Extension Service, 63 p.

Phillips, E. L., 1968, Washington climate for these counties - King, Kitsap, Mason, and Pierce: Washington State University Cooperative Extension Service, 66 p.

Phillips, E. L., 1975, Washington climate for these counties - Chelan, Douglas, and Okanogan: Washington State University Cooperative Extension Service, $71 \mathrm{p}$.

Phillips, K. N., 1941, Fumaroles of Mount St. Helens and Mount Adams: Mazama, v. 23 , no. 12 , p. 37-42.

Rasmussen, N. H., 1967, Washington State earthquakes 1840 through 1965: Seismological Society of America Bulletin, v. 57, no. 3, p. 463476.

Renner, J. L.; Lee, W. H., 1974, Geothermal land classification map, Western Region: U.S. Geological Survey Conservation Division, 1 map, 1:500,000.

Robinson, C. F., 1966, Stratigraphy and structural geology of Ahtanum Ridge, Yakima, Washington: University of Washington M.S. thesis, $35 \mathrm{p}$. 
Rocket Research Corporation, 1977, Industrial waste heat for adjacent communities and industrial applications, task 1: Rocket Research Company, Division of Rockcor, Inc., Redmond, Washington, table 3-7.

Schuster, J. E., 1974, Geothermal energy potential of Washington. In Energy Resources of Washington: Washington Division of Geology and Earth Resources Information Circular 50, p. 1-19.

Schuster, J. E., 1978 (personal communication): Washington Division of Geology and Earth Resources.

Schuster, J. E.; B1ackwe11, D. D.; Hammond, P. E.; Huntting, M. T., 1978, Heat flow studies in the Steamboat Mountain-Lemei Rock area, Skamania County, Washington: Washington Division of Geology and Earth Resources Information Circular 62, $56 \mathrm{p}$.

Sheppard, R. A., 1967, Petrology of a late Quaternary potassium-rich andesite flow from Mount Adams, Washington, Geological Survey Research, 1967: U.S. Geological Survey Professional Paper 575-C, p. C55-C59.

Tabor, R. W.; Crowder, D. E., 1969, On batholiths and volcanoes intrusions and eruption of late Cenozoic magmas in the Glacier Peak area, North Cascades, Washington: U.S. Geological Survey Professional Paper 604, $63 \mathrm{p}$.

Tabor, R. W.; Cady, W. T., 1978a, The structure of the 0lympic Mountains, Washington - Analysis of a subduction zone: U.S. Geological Survey Professional Paper 1033, $38 \mathrm{p}$.

Tabor, R. W.; Cady, W. M., 1978b, Geologic map of the 01ympic Peninsula, Washington: U.S. Geological Survey (Denver), 2 maps, 1:125,000.

Taylor, R., 1978 (personal communication): U.S. Forest Service Mount Baker-Snoqualmie National Forest.

Taylor, R., in preparation, Timber management plan: Mount Baker-Snoqualmie National Forest.

Unger, J. D.; Decker, R. W., 1970, The microearthquake activity of Mount Rainier, Washington: Seismological Society of America Bulletin, v. 60 , no. 6, p. 2023-2035.

Unger, J. D.; Mills, K. F., 1972, Microearthquakes at Mount Rainier 1969: Seismological Society of America Bulletin, v. 62, no. 4, p. 1079-1081.

Unger, J. D.; Mills, K. F., 1973, Earthquakes near Mount St. Helens, Washington: Geological Society of America Bulletin, v. 84, p. 1065-1068. 
U.S. Army Corps of Engineers, 1973, Environmental reconnaissance inventory of the State of Washington: U.S. Army Corps of Engineers, $51 \mathrm{p}$.

U.S. Bonneville Power Administration, 1974, Area office maps, sheet 2: U.S. Department of the Interior (Portiand), 1 map, 1:250,000.

U.S. Bonneville Power Administration, 1974, Area office maps, sheet 5: U.S. Department of the Interior (Port1and), 1 map, $1: 250,000$.

U.S. Bonneville Power Administration, 1974, Area office maps, sheet 8: U.S. Department of the Interior (Portland), 1 map, 1:250,000.

U.S. Bonneville Power Administration, 1974, Area office maps, sheet 9: U.S. Department of the Interior (Portiand), 1 map; 1:250,000.

U.S. Bonneville Power Administration, 1975, Area office maps, sheet 3: U.S. Department of the Interior (Portland), 1 map, 1:250,000.

U.S. Bonneville Power Administration, 1975, Area office maps, sheet 6: U.S. Department of the Interior (Portland), 1 map, 1:250,000.

U.S. Forest Service, 1976, Gifford Pinchot National Forest: U.S. Government Printing office (Portland), 1 map, 1:125,000.

U.S. Forest Service, 1977, Olympic National Forest and Park: U.S. Government Printing office (Portland), 1 map 1:126,720.

U.S. Forest Service, 1978, Mount Baker - Snoqualmie National Forest: U.S. Government Printing Office (Portland), 1 map, 1:125,000.

U.S. Geological Survey, 1928, Mount Rainier topographic quadrangle map, Washington, 30-minute series: U.S. Geological Survey (Denver), 1 map, 1:125,000.

U.S. Geological Survey, 1950a, Bogachiel Peak topographic quadrangle map, Washington, 15-minute series: U.S. Geological Survey (Denver), 1 map, 1:24,000.

U.S. Geological Survey, 1950b, Mount Carrie topographic quadrangle map, Washington 15-minute series: U.S. Geological Survey (Denver) 1 map, 1:24,000.

U.S. Geological Survey, 1952a, Glacier Peak topographic quadrangle map, Washington, 15-minute series: U.S. Geological Survey (Denver), 1 map, 1:62,500. 
U.S. Geological Survey, 1952b, Lake Shannon topographic quadrangle map, Washington, 15-minute series: U.S. Geological Survey (Denver), 1 map, 1:62,500.

U.S. Geological Survey, 1953a, Mount Shuksan topographic quadrangle map, Washington, 15-minute series: U.S. Geological Survey (Denver), 1 map, 1:62,500.

U.S. Geological Survey, 1953b, Yakima East topographic quadrangle Washington, 7.5-minute series: U.S. Geological Survey (Denver), 1 map, 1:24,000.

U.S. Geological Survey, 1957, Wind River topographic quadrangle map, Washington, 15-minute series: U.S. Geological Survey (Denver), 1 map, 1:62,500.

U.S. Geological Survey, 1958a, Fort Simcoe topographic quadrangle, Washington, 7.5-minute series: U.S. Geologica1 Survey (Denver), 1 map, 1:24,000.

U.S. Geological Survey, 1958b, Yakima West topographic quadrangle map, Washington, 7.5-minute series: U.S. Geological Survey (Denver), 1 map, 1:24,000.

U.S. Geological Survey, 1961, Mount St. Helens topographic quadrangle, Washington, 15-minute series: U.S. Geological Survey (Denver), 1 map, 1:62,500.

U.S. Geological Survey, 1970a, Mount Adams East topographic quadrangle map, 7.5-minute series: U.S. Geological Survey (Denver), 1 map, 1:24,000.

U.S. Geological Survey, 1970b, Mount Adams West topographic quadrangle map, 7.5-minute series: U.S. Geological Survey (Denver), 1 map, $1: 24,000$.

U.S. Geological Survey, 1975, Aeromagnetic map for pant of southwestern Washington: U.S. Geological Survey Open-File Report 75-648, 4 sheets, $1: 62,500$.

Verhoogen, J., 1937, Mount St. Helens - A Recent Cascade volcano: University of California Department of Geological Sciences Bulletin, v. 24, no. 9, p. 263-302.

Vice, D., 1978 (personal communication): Burlington Northern Energy and Minerals Department (Billings, Montana).

Waring, G. A., 1965, Thermal springs of the United States and other countries of the world - A summary: U.S. Geological Survey Professional Paper 492, 383 p. 
Washington Department of Ecology, 1977, Washington State water quality standards (Washington Administrative Code (WAC) chapter 173$201 \mathrm{WAC}$ ): Washington Department of Ecology Water Quality Planning, $33 \mathrm{p}$.

Washington State Highway Commission, 1975, Washington State Highways: Washington Department of Highways (01ympia), 1 map.

Washington Office of Financial Management, 1977, State of Washington. pocket data book, 1977: Washington Office of Financial Management, 276 p.

Wheeler, B., 1978, Geothermal leasing and development, Gifford Pinchot National Forest draft environmental analys is report: U.S. Forest Service Gifford Pinchot National Forest, $401 \mathrm{p}$.

White, D. E.; Williams, D. L., editors, 1975, Assessment of geothermal resources of the United States - 1975: U.S. Geological Survey Circular 726, $155 \mathrm{p}$.

Williams, F.; Cohen, A.; Pfundstein, R.; Pond, S., 1977, Site-specific analysis of geothermal development - data files of prospective sites, Baker Hot Springs, Washington: The Mitre Corporation Metrek Division, p. 14-1 to 14-12.

Wilson, J. T., 1965, Transform faults, oceanic ridges, and magnetic anomalies southwest of Vancouver Island: Science, v. 150, p. 482 . 


\section{APPENDIX}

I. GEOTHERMAL STEAM ACT OF 1970

II. RCW 79.76 (Geothermal Resources Act) 
APPENDIX I

GEOTHERMAL STEAM ACT OF 1970

PUBLIC LAW 91-581; 84 STAT. 1566

An Act to suthorize the Secretary of the Interior to make disposition of geothermal steam and associated geothermal resources, and for other purposes.

Be it enacted by the Senate and House of Representatives of the United States of America in Congress assembled, That:

This Act may be cited as the "Geothermal Steam Act of 1970".

Sec. 2. As used in this Act, the term-

(a) "Secretary" means the Secretary of the Interior;

(b) "geothermal lease" means a lease issued under authority of this Act;

(c) "geothermal steam and associated geothermal resources" means (i) all products of geothermal processes, embracing indigenous steam, hot water and hot brines; (ii) steam and other gases, hot water and hot brines resulting from water, gas, or other fluids artificially introduced into geothermal formations; (iii) heat or other associated energy found in geothermal formations; and (iv) any bypraduct derived frnm them;

(d) "byproduct" means any mineral or minerals (exclusive of oil, hydrocarbon gas, and helium) which.are found in solution or in association with geathermal steam and which have a value of less than 75 per centum of the value of the geothermal steam or are not, because of quantity, quality; or technical difficulties in extraction and production, of sufficient value to warrant extraction and production by themselves;

(e) "known geothermal resources area" means an area in which the geology, nearby discoveries, competitive interests, or other indicia would, in the opinion of the Secretary, engender a belief in men who are experienced in the subject matter that the prospects for extraction of geothermal steam or associated geothermal resources are good enough to warrant expenditures of money for that purpose.

Sec. 3. Subject to the provisions of section 15 of this Act, the Secretary of the Interior may issue leases for the development and utilization of geothermal steam and associated geothermal resources (1) in lands administered by him, including public, withdrawn, and acquired lands, (2) in any national forest or other lands administered by the Department of Agriculture through the Forest Services, including public, 
withdrawn, and acquired lands, and (3) in lands which have been conveyed by the United States subject to a reservation to the United States of the geothermal steam and associated geothermal resources therein.

Sec. 4. If lands to be leased under this Act are within any known geothermal resources area, they shall be leased to the highest responsible qualif ied bidder by competitive bidding under regulations formulated by the Secretary. If the lands to be leased are not within any known geothermal resources area, the qualified person first making application for the lease shall be entitled to a lease of such lands without competitive bidding. Notwithstanding the foregoing, at any time within one hundred and eighty days following the effective date of this Act:

(a) with respect to all lands which vere on September 7, 1965, subject to valid leases or permits issued under the Mineral Leasing Act of February 25, 1920, es amended ( 30 U.S.C. 181 et seq.), or under the Mineral Leasing Act of Acquired Lands, as amended ( 30 U.S.C. 351,358), or to existing mining claims located on or prior to September 7, 1965 , the lessees or permittees or claimants or their successors in interest who are qualified to hold geothermal leases shall have the right to convert such leases or permits or claims to geothermal leases covering the same lends;

(b) where there are conflicting clains, leases, or permits therefor embracing the same land, the person who first was issued a lease or permit, or who first recorded the mining claim shall be entitled to first consideration;

(c) with respect to 811 lands which were on September 7, 1965, the subject of applications for leases or permits under the above Acts, the applicants may convert their applications to applications for geothermal leases having priorities dating from the time of filing of such applications under such Acts;

(d) no person shall be permitted to convert mineral leases, permits, applications therefor; or mining claims for more than 10,240 acres; and

(e) the conversion of leases, permits, and mining claims and applications for leases and permits shall be accomplished in accordance with regulations prescribed by the Secretary. No right to conversion to a geothermal lease shall accrue to any person under this section unless such person shows to the reasonable satisfaction of the Secretary that substantial expenditures for the exploration, development, or production of geothermal stean have been made by the applicant who is seeking conversion, on the lands for which a lease is sought or on adjoining, adjacent, or nearby federal or non-federal lands. 
(f) with respect to.lands within any known geothermal resources area and which are subject to a right to conversion to a geothermal lease, such lands shall be leased by competitive bidding: Provided, That, the competitive geothermal lease shall be issued to the person owning the right to conversion to a geothermal lease if he makes payment of an amount equal to the highest bona fide bid for the competitive geothermal lease, plus the rental for the first year, within thirty days after he receives written notice from the Secretary of the amount of the highest bid.

Sec. 5. Geothermal leases shall provide for--

(a) a royalty of not less than 10 per centum or more than 15 per centum of the amount or value of steam, or any other form of heat or energy derived from production under the lease and sold or utilized by the lessee or reasonably susceptible to sale or utilization by the lessee;

(b) a royalty of not more than 5 per centum of the value of any byproduct derived from production under the lease and sold or utilized or reasonably susceptible of sale or utilization by the lessee, except that as to any byproduct which is a mineral named in section 1 of the Mineral Leasing Act of February 25, 1920, as amended (30 U.S.E. Loi), the rate of royalty for such mineral shall be the same as that provided in that Act and the maximum rate of royalty for such mineral shall not exceed the maximum royalty applicable under that Act;

(c) payment in advance of an annual rental of not less than $\$ 1$ per acre or fraction thereof for each year of the lease. If there is no vell on the leased lands capable of producing geothermal resources in cominercial quantities, the failure to pay rental on or before the anniversary date shall terminate the lease by operation of law: Provided, however, That whenever the Secretary discovers that the rental payment due under a lease is paid timely but the amount of the payment is deficient because of an error or other reason and the deficiency is nominal, as determined by the Secretary pursuant to regulations prescribed by him, he shall notify the lessee of the deficiency and such lease shall not automatically terminate unless the lessee fails to pay the deficiency within the period prescribed in the notice: Provided further, That, where any lease has been terminated automatically by operation of law under this section for failure to pay rental timely and it is shown to the satisfaction of the Secretary of the Interior that the failure to pay timely the lease rental was justifiable or not due to a lack of reasonable diligence, he in his judgment may reinstate the lease if --

(1) a petition for reinstatement, together with the required rental, is filed with the Secretary of the Interior; and 
(2) no valid lease has been issued affecting any of the lands in the terminated lease prior to the filing of the petition for reinstatement; and (d) a minimum royalty of $\$ 2$ per acre or fraction thereof in lieu of rental payable at the expiration of each lease year for each producing lease, commencing with the lease year beginning on or after the commencement of production in conmercial quantities. For the purpose of determining royalties hereunder the value of any geothermal steam and byproduct used by the lessee and not sold and reasonably susceptible of sale shall be determined by the Secretary, who shall take into consideration the cost of exploration and production and the economic value of the resource in terms of its ultimate utilization.

Sec. 6. (a) Geothermal leases shall be for a primary term of ten years. If geothermal steam is produced or utilized in comnercial quantities within this term, such lease shall continue for so long thereafter as geothermal steam is produced or utilized in commercial quantities, but such continuation shall not exceed an additional forty years.

(b) If, at the end of such forty years, steam is produced or utilized in comercial quantities and the lands are not needed for other purposes, the lessee shall have a preferential right to a renewal of such lease for a second forty-year term in accordance with such terms and conditions as the Secretary deems appropriate.

(c) Any lease for land on which, or for which under an approved cooperative or unit plan of development or operation, actual drilling operations vere commenced prior to the end of its primary term and are being diligently prosecuted at that time shall be extended for five years and so long thereafter, but not more than thirtyfive years, as geothermal steam is produced or utilized in comercial quantities. If, at the end of such extended term, steam is being produced or utilized in conmerclal quantities and the lands are not needed for other purposes, the lessee shall have a preferential right to a renewal of such lease for a second term in accordance with such terms and conditions as the Secretary deems appropriate.

(d) For purposes of subsection (a) of this section, production or utilization of geothermal steam in commercial quantities shall be deemed to include the completion of one or more wells producing or capable of producing geothermal steam in comnercial quantities and a bona fide sale of such geothermal steam for delivery to or utilization by a facility or facilities not yet installed but scheduled for installation not later than fifteen years from the date of commencement of the primary term of the lease. 
(e) Leases which have extended by reasons of production, or which have produced geothermal steam, and have been determined by the Secretary to be incapable of further commercial production and utilization of geothermal steam may be further extended for a period of not more than five years from the date of such determination but only for so long as one or more valuable byproducts are produced in commercial quantities. If such byproducts are leasable under the Mineral Leasing Act of February 25, 1920, as amended (30 U.S.C. 181, et seq.), or under the Mineral Leasing Act for Acquired Lands ( 30 U.S.C. 351-358), and the leasehold is primarily valuable for the production thereof, the lessee shall be entitled to convert his geothermal lease to a mineral lease under, and subject to all the terms and conditions of, such appropriate Act upon application at any time before expiration of the lease extension by reason of byproduct production. The lessee shall be entitled to locate under the mining laws all minerals which are not leasable and which would constitute a byproduct if commercial production or utilization of geothermal steam continued. The lessee in order to acquire the rights herein granted him shall complete the location of mineral claims within ninety days after the termination of the lease for geothermal steam. Any such converted lease or the surface of any mining claim locsted for igeothernal byproducts mineral laf fecting lands withdrawnor acquired in aid of a function of a Federal department or agency, including the Department of the Interior, shall be subject to such additional terms and conditions as may be prescribed by such department or agency with respect to the additional operations or effects resulting from such conversion upon adequate utilization of the lands for the purpose for which they are administered.

(f) Minerals locatable under the mining laws of the United States in lands subject to a geothermal lease issued under the provisions of this Act which are not associated with the geothermal steam and associated geothermal resources of such lands as defined in section 2(c) herein shall be locatable under said mining laws in accordance with the principles of the Multiple Mineral Development Act (68 Stat. 708; found in 30 U.S.C. 521 et seq.).

Sec. 7. A geothermal lease shall embrace a reasonably compact area of not more than two thousand five hundred and sixty acres, except where a departure therefrom is accasioned by an irregular subdivision or subdivisions. No person, association, or corporation, except as otherwise provided in this Act, shall take, hold, own, or control at one time, whether acquired directly from the Secretary under this Act or otherwise, any direct or indirect interest in Federal geothermal leases in any one State exceeding twenty thousand four hundred and eighty acres, including leases acquired under the provisions of section 4 of this Act. 
At any time after fifteen years from the effective date of this Act the Secretary, after public hearings, may increase this maximum holding in any one State by regulation, not to exceed fifty-one thousand two hundred acres.

Sec. 8. (a) The Secretary may. readjust the terms and conditions, except as otherwise provided herein, of any geothermal lease issued under this Act at not less than ten-year intervals beginning ten years after the date the geothermal steam is produced, as determined by the Secretary. Each geothermal lease issued under this Act shall provide for such readjustment. The Secretary shall give notice of any proposed readjustment of terms and conditions, and, unless the lessee files with the Secretary objection to the proposed terms or relinquishes the lease within thirty days after receipt of such notice, the lessee shall conclusively be deemed to have agreed with such terms and conditions. If the lessee files objections, and no agreement can be reached between the Secretary and the lessee within a period of not less than sixty days, the lease may be terminated by either party.

(b) The Secretary may readjust the rentals and royalties of any geothermal lease issued under this Act at not less than twenty-year intervals beginning thirty-five years after the date geothermal steam is produced, es determined by the Secretary. In the event of any such readjustment neither the rental nor royalty may be increased by more than 50 per centum over the rental or royalty paid during the preceding period, and in no event shall the royalty payable exceed $22 \frac{1}{5}$ per centum. Each geothermal lease issued under this Act shall provide for such readjustment. The Secretary shall give notice of any proposed readjustment of rentals and royalties, and, unless the lessee files with the Secretary objection to the proposed rentals and royalties or relinquishes the lease within thirty days after receipt of such notice, the lessee shall conclusively be deemed to have agreed with such terms and conditions. If the lessee files objections, and no agreement can be reached between the Secretary and the lessee within a period of not less than sixty days, the lease may be terminated by either party.

(c). Any readjustment of the terms and conditions as to use, protection, or restoration of the surface of any lease of lands withdrawn or acquired in aid of a function of a Federal department or agency other than the Department of the Interior may be made only upon notice to, and with the approval of, such department or agency.

Sec. 9. If the production, use, or conversion of geothermal steam is susceptible of producing a valuable byproduct or byproducts, including commercially demineralized vater for beneficial uses in accordance with applicable state water Jaws, the Secretary shall require substantial beneficial production or use thereof unless, in individual circumstances he modifies or waives this requirement in the interest of 
conservation of natural resources or for other reasons satisfactory to him. However, the production or use of such byproducts shall be subject to the rights of the holders of preexisting leases, claims, or permits covering the same land or the same minerals, if any.

Sec. 10. The holder of any geothermal lease at any time may make and file in the appropriate land of $f$ ice a written relinquishment of all rights under such lease or of any legal subdivision of the area covered by such lease. Suct relinquishment shall be effective as of the date of its filing. Thereupon the lessee shall be released of all obligations thereafter accruing under said lease with respect to the lands relinquished, but no such relinquishment shall release such lessee, or his surety or bond, from any liability for breach of any obligation of the lease, other than an obligation to drill, accrued at the date of the relinquishment, or from the continued obligation, in accordance with the applicable lease terms and regulations, (1) to make payment of all accrued rentals and royalties, (2) to place all wells on the relinquished lands in condition for suspension or abandonment, and (3) to protect or restore substantially the surface and surface resources.

Sec. 11. The Secretary, upon application by the lessee, may authorize the lessee to suspend operations and production on a producing lease and he may, on his own motion, in the interest of conservation suspend operations on any lease but in either case he may extend the lease term for the period of any suspension, and he may waive, suspend, or reduce the rental or royalty required in such lease.

Sec. 12. Leases may be terminated by the Secretary for any violation of the regulations or lease terms after thirty days notice provided that such violation is not corrected within the notice period, or in the event the violation is such that it cannot be corrected within the notice period then provided that lessee has not commenced in good faith within said notice period to correct such violation and thereaf ter to proceed diligently to correct such violation. Lessee shall be entitled to a hearing on the matter of such claimed violation or proposed termination of lease if request for a hearing is made to the Secretary within the thirty-day period after notice. The period for correction of violation or commencement to correct such violation of regulations or of lease terms, as aforesaid, shall be extended to thirty days after the Secretary's decision after such hearing if the Secretary shall find that a violation exists.

Sec. 13. The Secretary may waive, suspend, or reduce the rental or royalty for any lease or portion thereof in the interests of conservation and to encourage the greatest ultimate recovery of geothermal resources, if he determines that this is necessary to promote development or that the lease cannot be successfully operated under the lease terms. 
Sec. 14. Subject to the other provisions of this Act, a lessee shall be entitled to use so much of the surface of the land covered by his geothermal lease as may be found by the Secretary to be necessary for the production, utilization, and conservation of geothermal resources.

Sec. 15. (a) Geothermal leases for lands withdrawn or acquired in aid of functions of the Department of the Interior may be issued only under such terms and conditions as the Secretary may prescribe to insure adequate utillization of the lands for the purposes for which they vere withdrawn or acquired.

(b) Geothermal leases for lands withdrain or acquired in aid of functions of the Department of Agriculture nay be Issued only with the consent of, and subject to such terms and conditions as may be prescribed by, the head of that Department to insure adequate utilization of the lands for the purposes for which they were withdrawn or acquired. Geothermal leases for lands to which section 24 of the federal Power Act, as amended (16 U.S.C. 818), is applicable, may be issued only with the consent of, and subject to, such terms and conditions as the Federal Power Commission may preseribe to insure adequate utilization of such lands for pover and related purposes.

(c) Geothermal leases under this Act shall not be issued for lands administered in accordance with (1) the Act of August 25, 1916 (39 Stat. 535), as anended or supplemented, (2) for lands within a national recreation area, (3) for lands in a fish hatchery administered by the Secretary, wildlife refuge, wildlife range, game range, vildlife management area, vaterfowl production area, or for lands acquired or reserved for the protection and conservation of Fish and wildlife that are threatened with extinction, (4) for tribally or individually ouned Indian trust or restricted lands, within or without the boundaries of Indian reservations.

Sec. 16. Leases under this Act may be issued only to citizens of the United States, associations of such citizens, corporations organized under the laws of the United States or of any State or the District of Columbia, or governmental units, including, without limitation; municipallties.

Sec. 17. Administration of this Act shall be under the principles of multiple use of lands and resources, and geothermal leases shall, insofar as feasible, allow for coexistence of other leases of the same lands for deposits of minerals under the laws applicable to them, for the location and production of claims under the mining laws, and for other uses of the areas covered by them. Operations under such other leases or for such other uses, hovever, shall not unreasonably interfere with or 
endanger operations under any lease issued pursuant to this Act, nor shall operations under leases so issued unreasonably interfere with or endanger operations under any lease, license, claim, or permit issued pursuant to the provisions of any other Act.

Sec. 18. For the purpose of properly conserving the natural resources of any geothermal pool, field, or like area, or any part thereof, lessees thereof and their representatives may unite with each other, or jointly or separately with others, in collectively adopting and operating under a cooperative or unit plan of development or operation of such pool, field, or like erea, or any part thereof, whenever this is determined and certified by the Secretary to be necessary or advisable in the public interest. The Secretary may in his discretion and with the consent of the holders of leases involved, establish, alter, change, revoke, and make such regulations with reference to such leases in connection with the institution and operation of any such cooperative or unit plan as he may deem necessary or proper to secure reasonable protection of the public interest. He may include in geothermal. leases a provision requiring the lessee to operate under such a reasonable cooperative or unit plan, and he may prescribe such a plan under which such lessee shall operate, which shall, adequately protect the rights of all parties in interest, including the United States. Any such plan may, in the discretion of the Secretary, provide for vesting in the Secretary or any other person, committee, or Federal or State agency designated therein, authority to alter or modify from time to time the rate of prospecting and development and the quantity and rate of production under such plan. All leases operated under any such plan approved or prescribed by the Secretary shall be excepted in determining holdings or control for the purposes of section 7 of this Act.

When separate tracts cannot be independently developed and operated in conformity with an established well-spacing or development program, any lease, or a portion thereof, may be pooled with other lands, whether or not owned by the United States, under a communitization or drilling agreement providing for an apportionment of production or royalties among the separate tracts of land comprising the orilling or spacing unit when determined by the Secretary to be in the public interest, and operations or production pursuant to such an agreement shall be deemed to be operations or production as to each lease committed thereto.

The Secretary is hereby authorized, on such conditions as he may prescribe, to approve operating, drilling, or development contracts made by one or more lessees of geothermal leases, with one or more persons, associations, or corporations whenever, in his discretion, the conservation of natural products or the public convenience or necessity may require or the interests of the United States may be best served thereby. All leases operated under such approved operating, drilling, or development contracts, and interests thereunder, shall be excepted in determining holdings or control under section 7 of this Act. 
Sec. 19. Upon request of the Secretary, other Federal departments and agencies shall furnish him with any relevant data then in their possession or knowledge concerning or having bearing upon fair and adequate charges to be made for geothermal steam produced or to be produced for conversion to electric power or other purposes. Date given to any department or agency as confidential under law shall not be furnished in any fashion which identifies or tends to identify the business entity whose activities are the subject of such data or the person or persons who furnished such information.

Sec. 20 All moneys received under this Act from public lands under the jurisdiction of the Secretary shall be disposed of in the same manner as moneys received from the sale of public lands. Moneys received under this Act from other lands shall be disposed of in the same manner as other receipts from such lands.

Sec. 21. (a) Within one-hundred and twenty days after the effective date of this Act; the Secretary shall cause to be published in the Federal Register a determination of all lands which were included within eny known geothermal resources area on the effective date of the Act. He shall likewise publish in the Federal Register from time to time his determination of other known geothermal resources areas specifying in each case the date the lands were included in such area; and

(b) Geothermal resources in lands the surface of which has passed from federal ownership but in which the minerals have been reserved to the United States shall not be developed or produced except under geothermal leases made pursuant to this Act. If the Secretary of the Interior finds that such development is imminent, or that production from a well heretofore drilled on such lands is imminent, he shall so report to the Attorney General, and the Attorney General is authorized and directed to institute an appropriate proceeding in the United States district court of the district in which such lands are located, to quiet the title of the United States in such resources, and if the court determines that the reservation of minerals to the United States in the lands involved included the geothermal resources, to enjoin their production otherwise than under the terms of this Act: Provided, That upon authoritative judicial determination that federal mineral reservation does not include geothermal steam and associated geothermal resources the duties of the Secretary of the Interior to report and of the Attorney Ceneral to institute proceedings, as hereinbefore set forth, shall cease.

Sec. 22. Nothing in this Act shall constitute an express or Implied claim or denial on the part of the federal Government as to its exemption from State water laws.

Sec. 23. (a) All leases under this Act shall be subject to the condition that the lessee vill, in conducting his exploration, development, and producing operations, use all reasonable precautions to prevent vaste of geothermal steam and associated geothermal resources developed in the lands leased. 
(b) Rights to develop and utilize geothermal steam and associated geothermal resources underlying lands ouned by the United States may be acquired solely in accordance with the provisions of this Act.

Sec. 24. The Secretary shall prescribe such rules and regulations as he may deem appropriate to carry out the provisions of this Act. Such regulations may include, without limitation, provisions for (a) the prevention of waste, (b) development and conservation of geothermal and other natural resources, (c) the protection of the public interest, (d) assignment, segregation, extension of terms, relinquishment of leases, development contracts, unitization, pooling, and drilling agreements,

(e) compensatory royalty agreements, suspension of operations or production, and suspension or reduction of rentals or royalties, (f) the filing of surety bonds to assure compliance with the terms of the lease and to protect surface use and re(2) sources, (g) use of the surface by a lessee of the lands embraced in his lease, (h) the maintenance by the lessee of an active development program, and (i) protection of water quality and other environmental qualities.

Sec. 25. As to any land subject to geothermal leasing under section 3 of this Act, all laws which either (a) provide for the disposal of land by patent or other form of conveyance or by grant or by operation of lay subject to a reservation of any mineral or (b) prevent or restrict the disposal of such land because of the mineral character of the land, shall hereafter be deemed to embrace geothermal steam and associated geothermal resources as a substance which either must be reserved or must prevent or restrict the disposal of such land, as the case may be. This section shall not be construed to affect grants, patents, or other forms of conveyances made prior to the date of enactment of this Act.

Sec. 26. The first two clauses in section 11 of the Act of August 13, 1954 (68 Stat. 708, 716)', are amended to read as follows:

"As used in this Act, 'mineral leasing laws' shall mean the Act of February 25 , 1920 (41 Stat. 437); the Act of April 17, 1926 (44 Stat. 301); the Act of February 7, 1927 (44 Stat. 1057); Geothermal Steam Act of 1970, and all Acts heretofore or hereafter enacted which are amendatory of or supplementary to any of the foregoing Acts; 'Leasing Act minerals' shall mean all minerals which, upon the effective date of this Act, are provided in the mineral leasing laws to be disposed of thereunder and all geothermal steam and associated geothermal resources which, upon the effective date of the Geothermal Steam Act of 1970, are provided in that Act to be disposed of thereunder;".

Sec. 27. The United States reserves the ownership of and the right to extract under such rules and regulations as the Secretary may prescribe oil, hydrocarbon gas, and helium from all geothermal steam and associated geothermal resources produced

' 30 U.S.C.A. 5 
from lands leased under this Act in accordance with presently applicable laws:

Provided, That whenever the right to extract oil, hydrocarbon gas, and helium from geothermal steam and associated geothermal resources produced from such lands is exercised pursuant to this section, it shall be exercised so as to cause no substantial interference with the production of geothermal steam and associated geothermal resources from such lands.

Approved December 24, 1970. 
Appendix II

RCW 97.76

State of Washington 43rd Legislature 3rd Extraordinary Session by Cormittee on Natural Resources (Originally sponsored by Representatives Paris, Kilbury, Zimmerman, Douthwaite and Charnley - by Legislative Council request)

Read first time January 24, 1974, and passed to second reading. AN ACT Relating to conservation of geothermal resources; authorizing the department of natural resources to administer this act and defining its powers and duties; authorizing certain practices subject to the provisions of this act and departmental rules and regulations; requiring performance bonds or in lieu securities; requiring the keeping and filing of certain records; prescribing certain fees and providing for the disposition thereof; adding a new chapter to Title $79 \mathrm{RCW}$; providing certain civil and criminal remedies; and prescribing penalties.

BE IT ENACTED BY THE LEGISLATURE OF THE STATE OF WASHINGTON:

NEW SECTION. Section 1. The public has a direct interest in the safe, orderly and nearly pollution-free development of the geothermal resources of the state, as hereinafter in section 3 (1) of this 1974 act defined. The legislature hereby declares that it is in the best interests of the state to further the development of geothermal resources for the benefit of all of the citizens of the state while at the same time fully providing for the protection of the environment. The development of geothermal resources shall be so conducted as to protect the rights of landowners, other owners of interests therein, and the general public. In providing for such development, it is the purpose of this chapter to provide for the orderly exploration, safe drilling, production and proper abandonment of geothermal resources in the state of Washington.

NEU SECTION. Sec. 2. This chapter shall be known as the Geotherma1 Resources Act.

NEW SECTION. Sec. 3. For the purposes of this chapter, 
unless the text otherwise requires, the following terms shall have the following meanings:

(1) "Geothermal resources" means only that natural heat energy of the earth from which it is technologically practical to produce electricity commercially and the medium by which such heat energy is extracted from the earth, including liquids or gases, as well as any minerals contained in any natural or injected fluids, brines and associated gas, but excluding ofl, hydrocarbon gas and other hydrocarbion substances.

(2) "Waste", in addition to its ordinary meaning, shall mean "physical waste" as that term is generally understood and shall include:

(a) The inefficient, excessive, or improper use of, or unnecessary dissipation of, reservoir energy; or the locating, spacing, drflling, equipping, operating or producing of any geothermal energy well in a manner which results, or tends to result, in reducing the quantity of geothermal energy to be recovered from any geothermal area in this state;

(b) The inefficient above-ground transporting or storage of geothermal energy; or the locating, spacing, drilling, equipping, operating, or producing of any geothermal well in a manner causing, or tending to cause, unnecessary excessive surface loss or destruction of geothermal energy;

(c) The escape into the open air, from a well of steam or hot water, in excess of what is reasonably necessary in the efficient development or production of a geothermal well.

(3) "Geothermal area" means any land that is, or reasonably appears to be, underlain by geothermal resources.

(4) "Energy transfer system" means the structures and enclosed fluids which facilitate the utilization of geothermal energy. The system includes the geothermal wells, cooling towers, reinjection wells, equipment directly involved in converting the heat energy associated with geothermal resources to mechanical or electrical 
energy or in transferring it to another fluid, the closed piping between such equipment, wells and towers and that portion of the earth which facilitates the transfer of a fluid from reinjection wells to geothermal wells: PROVIDED, That the system shall not include any geothermal resources which have escaped into or have been released into the nongeothermal ground or surface waters from either man-made containers or through leaks in the structure of the earth caused by or to which access was made possible by any drilling, redrilling, reworking or operating of a geothermal or reinjection welt.

(5) "Operator" means the person supervising or in control of the operation of a geothermal resource well, whether or not such person is the owner of the well.

(6) "Owner" means the person who possesses the legal right to drill, convert or operate any well or other facility subject to the provisions of this chapter.

(7) "Person" means any individual, corporation, company, association of individuals, joint venture, partnership, receiver, trustee, guardian, executor, administrator, personal representative, or public agency that is the subject of legal rights and duties.

(8) "Pollution" means any damage or injury to ground or surface waters, soil or air resulting from the unauthorized loss, escape, or disposal of any substances at any well subject to the provisions of this chapter.

(9) "Department" means the department of natural resources.

(10) "We11" means any excavation made for the discovery or production of geothermal resources, or any special facility, converted producing facility, or reactivated or converted abandoned facility used for the reinjection of geothermal resources, or the residue thereof underground.

(11) "Core holes" are holes drilled or excavations made expressly for the acquisition of geological or geophysical data for the purpose of finding and delineating a favorable geothermal area 
prior to the drilling of a well.

(12) A "completed well" is a well that has been drilled to its total depth, has been adequately cased, and is ready to be either plugged and abandoned, shut-in, or put into production.

(13) "Plug and abandon" means to place permanent plugs in the well in such a way and at such intervais as are necessary to prevent future leakage of fluid from the well to the surface or from one zone in the well to the other, and to remove all drilling and production equipment from the site, and to restore the surface of the site to its natural condition or contour or to such condition as may be prescribed by the department.

(14) "Shut-in" means to adequately cap or seal a well to control the contained geothermal resources for an interim period.

NEW SECTION: Sec. 4. Notwithstanding any other provision of law, geothermal resources are found and hereby determined to be sui generis, being netther a mineral resource nor a water resource.

NEW SECTION. Sec. 5. (1) The department shall administer and enforce the provisions of this chapter and the rules, regulations, and orders relating to the drilling, operation, maintenance, abandonment and restoration of geothermal areas, to prevent damage to and waste from underground geothermal deposits, and to prevent damage to underground and surface waters, land or air that may result from improper drilling, operation, maintenance or abandonment of geothermal resource wells.

(2) In order to implement the terms and provisions of this chapter, the department under the provisions of chapter $34.04 \mathrm{RCW}$, as now or hereafter amended, may from time to time promulgate those rules and regulations necessary to carry out the purposes of this chapter, including but not restricted to defining geothermal areas; establishing security requirements, which may include bonding; providing for liens against production; providing for casing and safety device requirements; providing for site restoration plans to be completed prior to abandonment; and providing for abandonment 
requirements.

NEW SECTION. Sec. 6. This chapter is intended to preempt. local regulation of the drilling and operation of wells for geothermal resources but shall not be construed to permit the locating of any well or drilling when such well or drilling is prohibited under state or local land use law or regulations promulgated thereunder. Geothermal resources, byproducts and/or waste products which have escaped or been released from the energy transfer system and/or a mineral recovery process shall be subject to provisions of state law relating to the pollution of ground or surface waters (Title $90 \mathrm{RCW}$ ), provisions of the state fisheries law (Title $75 \mathrm{RCW}$ ), and the state game laws (Title $77 \mathrm{RCW}$ ), and any other state environmental pollution control laws. Authorization for use of byproduct water resources for all beneficial uses, including but not. limited to greenhouse heating, warm water fish propagation, space heating plants, irrigation, swimming pools, and hot springs baths, shall be subject to the appropriation procedure as provided in Title 90 RCW.

NEW SECTION. Sec. 7. (1) Any person proposing to drill a well or redrill an abandoned well for geothermal resources shall file with the department a written application for a permit to comence such drilling or redrilling on a form prescribed by the department accompanied by a permit fee of two hundred dollars. The department shall forvard a duplicate copy to the department of ecology within ten days of filing.

(2) Upon receipt of a proper application relating to drilling or redrilling the department shall set a date, time, and place for a public hearing on the application, which hearing shall be in the county in which the drilling or redrilling is proposed to be made, and shall instruct the applicant to publish notices of such application and hearing by such means and within such time as the department shall prescribe. The department shall require that the notice so prescribed shall be published twice in a newspaper of 
general circulation within the county in which the drilling or redrilling is proposed to be made and in such other appropriate information media as the department may direct.

(3) Any person proposing to drill a core hole for the purpose of gathering geothermal data, including but not restricted to heat flow, temperature gradients, and rock conductivity, shall be required to obtain a single permit for each geothermal area according to subsection (1) of this section, except that no permit fee shall be required, no notice need be published, and no hearing need be held. Such core holes that penetrate more than seven hundred and fifty feet into bedrock shall be deemed geothermal test wells and subject to the payment of a permit fee and to the requirement in subsection (2) of this section for public notices and hearing. In the event geothermal energy is discovered in a core hole, the hole shall be deemed a geothermal well and subject to the permit fee, notfces, and hearing. Such core holes as described by this subsection are subject to all other provisions of this chapter, including a bond or other security as specified in section 13 of this act.

(4) All moneys paid to the department under this section shall be deposited with the state treasurer for credit to the general fund.

NEW SECTION. Sec. 8. A permit shall be granted only if the department is satisfied that the area is suitable for the activities applied for; that the applicant will be able to comply with the provisions of this chapter and the rules and regulations enacted hereunder; and that a permit would be in the best interests of the state.

The department shall not allow operation of a well under permit if it finds that the operation of any well will unreasonably decrease ground water available for prior water rights in any aquifer or other ground water source for water for beneficial uses, unless such affected water rights are acquired by condemnation, purchase or other means.

The department shall have the authority to condition the 
permit as it deems necessary to carry out the provisions of this chapter, including but not limited to conditions to reduce any environmental impact.

The department shall forward a copy of the permit to the department of ecology within five days of issuance.

NEW SECTION. Sec. 9. Any operator engaged in drilling or operating a well for geothermal resources shall equip such well with casing of sufficient strength and with such safety devices as may be necessary, in accordance with methods approved by the department.

No person shall remove a casing, or any portion thereof, from any well without prior approval of the department.

NEW SECTION. Sec. 10. Any well drilled under authority of this chapter from which:

(1) It is not technologically practical to derive the energy to produce electricity commercially, or the owner or operator has no intention of-deriving energy to produce electricity cormercially, and

(2) Usable minerals cannot be derived, or the owner or operator has no intention of deriving usable minerals, shall be plugged and abandoned as provided in this chapter or, upon the owner's or operator's written application to the department of natural resources and with the concurrence and approval of the department of ecology, jurisdiction over the well may be transferred to the department of ecology and, in such case, the well shall no longer be subject to the provisions of this chapter but shall be subject to any applicable laws and regulations relating to wells drilled for appropriation and use of ground waters. If an application is made to transfer jurisdiction, a copy of all logs, . records, histories, and descriptions shall be provided to the department of ecology by the applicant.

NEW SECTION. Sec. 11. (1) The department may authorize the operator to suspend drilling operations, shut-in a completed well, or remove equipment from a well for the period stated in the department's written authorization. The period of suspension may be 
extended by the department upon the operator showing good cause for the granting of such extention.

(2) If drilling operations are not resumed by the operator, or the well is not put into production, upon expiration of the suspension or shut-in permit, an intention to unlawfully abandon shall be presumed:

(3) A well shall also be deemed unlawfully abandoned if, without written approval from the department, drilling equipment is removed.

(4) An unlawful abandonment under this chapter shall be entered in the department records and written notice thereof shall be mailed by registered mail both to such operator at his last known address as disclosed by records of the department and to the operator's surety. The department may thereafter proceed against the operator and his surety.

NEW SECTION. Sec. 12. (1) Before any operation to plug and abandon or suspend the operation of any well is commenced, the owner or operator shall submit in writing a notification of abandonment or suspension of operations to the department for approval. No operation to abandon or suspend the operation of a well shall commence without approval by the department. The department shall respond to such notification in writing within ten working days following receipt of the notification.

(2) Failure to abandon or suspend operations in accordance with the method approved by the department shall constitute a violation of this chapter, and the department shall take appropriate action under the provisions of section 27 of this 1974 act.

NEW SECTION. Sec. 13. Every operator who engages in the drilling, redrilling, or deepening of any well shall file with the department a reasonable bond or bonds with good and sufficient surety, or the equivalent thereof, acceptable to the department, conditioned on compliance with the provisions of this chapter and all rules and regulations and permit conditions adopted pursuant to this 
chapter. This performance bond shall be executed in favor of and approved by the department.

In lieu of a bond the operator may file with the department a cash deposit, negotiable securities acceptable to the department, or an assignment of a savings account in a Washington bank on an assignment form prescribed by the department. The department, in its discretion, may accept a single surety or security arrangement covering more than one well.

NEIV SECTION. Sec. 14. The department shall not consent to the termination and cancellation of any bond by the operator, or change as to other security given, until the well or wells for which it has been issued have been properly abandoned or another valid bond for such well has been submitted and approved by the department. A well is properly abandoned when abandonment has been approved by the departmient.

NEW SECTION. Sec. 15. The owner or operator of a well shall notify the department in writing within ten days of any sale, assignment, conveyance, exchange, or transfer of any nature which results in any change or addition in the owner or operator of the well on such forms with such information as may be prescribed by the department.

NEW SECTION. Sec. 16. The department has the authority, through rules and regulations, to promulgate combining orders, unitization programs, and well spacing, and establish proportionate costs among owners of operators for the operation of such units as the result of said combining orders, if good and sufficient reason is demonstrated that such measures are necessary to prevent the waste of geothermal resources.

NEW SECTION. Sec. 17. Each owner or operator of a well shall designate a person who resides in this state as his agent upon whom may be served all legal processes, orders, notices, and directives of the department or any court.

NEW SECTION. Sec. 18. The department shall have the 
authority to conduct or authorize investigations, research, experiments, and demonstrations, cooperate with other governmental and private agencies in making investigations, receive any federal funds, state funds, and other funds and expend them on research programs concerning geothermal resources and their potential development within the state, and to collect and disseminate information relating to geothermal resources in the state: PROVIDED, That the department shall not construct or operate commercial geothermal facilities.

NEW SECTION. Sec. 19. The department shall have the authority, and it shall be its duty, to employ all personnel necessary to carry out the provisions of this chapter pursuant to chapter 41.06 RCW.

NEW SECTION. Sec. 20. (1) The owner or operator of any well shall keep or cause to be kept careful and accurate logs, records, descriptions, and histories of the drilling, redrilling, or deepening of the well.

(2) All logs, records, histories, and descriptions referred to in subsection (1) of this section shall be kept in the local office of the owner or operator, and together with other reports of the owner or operator shall be subject during business hours to inspection by the department. Each owner or operator, upon written request from the department, shall file with the department a copy of the logs, records, histories, descriptions, or other records portions thereof pertaining to the geothermal drilling or operation underway or suspended.

NEW SECTION. Sec. 21. Upon completion or plugging and abandonment of any well or upon the suspension of operations conducted with respect to any well for a period of at least six months, one copy of the $\log$, core record, electric log, history, and all other logs and surveys that may have been run on the well, shall be filed with the department within thirty days after such completion, plugging and abandonment, or six months' suspension. 
NEW SECTION. Sec. 22. The owner or operator of any well producing geothemal resources shall file with the department a statement of the geothermal resources produced. Such report shall be submitted on such forms and in such manner as may be prescribed by the department.

NEN SECTION. Sec. 23. (1) The records of any owner or operator, when filed with the department as provided in this chapter, shall be confidential and shall be open to inspection oniy to personnel of the department for the purpose of carrying out the provisions of this chapter and to those authorized in writing by such owner or operator, until the expiration of a twenty-four-month confidential period to begin at the date of commencement of production or of abandonment of the well.

(2) Such records shall in no case, except as provided in this chapter, be available as evidence in court proceedings. No officer, employee, or member of the department shall be allowed to give testimony as to the contents of such records, except as provided in this chapter for the review of a decision of the department or in any proceeding initiated for the enforcement of an order of the department, for the enforcement of a lien created by the enforcement of this chapter, or for use as evidence in criminal proceedings arising out of such records or the statements upon which they are based.

NEW SECTION. Sec. 24. No person shall, for the purpose of evading the provision of this chapter or any rule, regulation or order of the department made thereunder, remove from this state, or destroy, mutilate, alter or falsify any such record, account, or writing.

NEW SECTION. Sec. 25. Whenever it appears with probable cause to the department that:

(1) A violation of any provision of this chapter, regulation adopted pursuant thereto, or condition of a permit issued pursuant to this chapter has occurred or is about to occur, or 
(2) That a modification of a permit is deemed necessary to carry out the purpose of this chapter,

the department shall issue a written order in person to the operator or his employees or agents, or by certified mail, concerning the drilling, testing, or other operation conducted with respect to any well drilled, in the process of being drilled, or in the process of being abandoned or in the process of reclamation or restoration, and the operator, owner, or designated agent of either shall comply with the terms of the order and may appeal from the order in the manner provided for in section 28 of this 1974 act. When the department deems necessary the order may include a shutdown order to remain in effect until the deficiency is corrected.

NEW SECTION. Sec. 26. Any person who violates any of the provisions of this chapter, or fails to perform any duty imposed by this chapter, or violates an order or other determination of the department made pursuant to the provisions of this chapter, and in the course thereof causes the death of, or injury to, fish, animals, vegetation or other resources of the state, shall be liable to pay the state damages including an amount equal to the sum of money necessary to restock such waters, replenish such resources, and otherwise restore the stream, lake, other water source, or land to its condition prior to the injury, as such condition is determined by the department. Such damages shall be recoverable in an action brought by the attorney general on behalf of the people of the state of Washington in the superior court of the county in which such damages occurred: PROVIDED, That if damages occurred in more than one county the attorney general may bring action in any of the counties where the damage occured. Any moneys so recovered by the attorney general shall be transferred to the department under whose jurisdiction the damaged resource occurs, for the purposes of restoring the resource.

NEW SECTION. Sec. 27. Whenever it shall appear that any person is violating any provision of this chapter, or any rule, 
regulation, or order made by the department hereunder, and if the department cannot, without litigation, effectively prevent further violation, the department may bring suit in the name of the state against such person in the court in the county of the residence of the defendant, or in the county of the residence of any defendant if there be more than one defendant, or in the county where the violation is alleged to have occurred, to restrain such person from continuing such violation. In such suit the department may, without bond, obtain injunctions prohibitory and mandatory, including temporary restraining orders and preliminary injunctions, as the facts may warrant.

NEW SECTION. Sec. 28. (1) Any person adversely affected by any rule, regulation, order, or permit entered by the department pursuant to this chapter may obtain judicial review thereof in accordance with the applicable provisions of chapter $34.04 \mathrm{RCW}$.

(2) The court having jurisdiction, insofar as is practicable, shall give precedence to proceedings for judicial review brought under this chapter.

NEW SECTION. Sec. 29. Violation of any provision of this chapter or of any rule, regulation, order of the department, or condition of any permit made hereunder is punishable, upon conviction, by a fine of not more than two thousand five hundred dollars or by imprisonment in the county jail for not more than six months, or both.

NEW SECTION. Sec. 30. No person shall knowingly aid or abet any other person in the violation of any provision of this chapter or of any rule, regulation or order of the department made hereunder.

NEW SECTION. Sec. 31. Sections 1 through 30 of this 1974 act shall constitute a new chapter in Title 79 RCH.

NEH SECTION. Sec. 32. If any provision of this 1974 act, or its application to any person or circumstance is held invalid, the remainder of the act, or the application of the provision to other persons or circumstances is not affected. 